\title{
Oxide Dispersion Strengthened Iron Aluminide by CVD Coated Powders
}

\author{
Final Report \\ Award Number DE-FG36-03G013012 \\ Prepared for \\ The Department of Energy \\ Golden Field Office, Golden, CO
}

Asit Biswas \& Andrew J. Sherman

Powdermet Inc.

Euclid, Ohio 


\section{FOREWORD}

This report was prepared by the Powdermet Inc, Euclid, Ohio for the DOE I\&I proposal Category 2 entitled "Oxide Dispersion Strengthened Iron Aluminide by CVD coated Powders" Award Number DE-FG36-03GO13012. Fabrication and Evaluation of the Mechanical and Physical Properties of Iron Aluminide composites and its thermal sprayed coatings using chemical vapor deposition (CVD) aluminum, iron and aluminum oxide coated iron powders and iron, aluminum coated aluminum oxide powders were evaluated as part of a DOE I \& I Category 2 Program following the successful completion of a preceding SBIR Phase-I assignment on the same subject. The objective of this program was to develop and optimize CVD aluminum, iron and aluminum oxide coated iron powders and iron, aluminum coated aluminum oxide powders for thermal spray application and optimize the fabrication of this Iron Aluminide composites, and it's coatings and evaluate the performances of these new materials for potential use as high temperature, oxidation, corrosion and carburization resistant material aimed for future power generation and boiler equipment. The program developed CVD coated powders demonstrated the fabrication of oxide dispersion strengthened (ODS) $\mathrm{Fe}_{3} \mathrm{Al}$ composites with a tensile value of $121 \mathrm{KSI}$ and oxidation, carburization and corrosion resistant thermal sprayed coating The Prime Contract manager was Mr. Asit Biswas, of Powdermet, Inc., and the subject DOE I \&I Program was monitored by HQ I\&I Technology Manager: Lisa Barnett, Project Officer: Deborah Weems, Project Monitor: Tony Newville, and Financial /Officer: Michael Schledorn. 


\begin{abstract}
This I \&I Category2 program developed chemical vapor deposition (CVD) of iron, aluminum and aluminum oxide coated iron powders and the availability of high temperature oxidation, corrosion and erosion resistant coating for future power generation equipment and can be used for retrofitting existing fossil-fired power plant equipment. This coating will provide enhanced life and performance of Coal-Fired Boilers components such as fire side corrosion on the outer diameter (OD) of the water wall and superheater tubing as well as on the inner diameter (ID) and OD of larger diameter headers. The program also developed a manufacturing route for readily available thermal spray powders for iron aluminide coating and fabrication of net shape component by powder metallurgy route using this CVD coated powders.

This coating can also be applid on jet engine compressor blade and housing, industrial heat treating furnace fixtures, magnetic electronic parts, heating element, piping and tubing for fossil energy application and automotive application, chemical processing equipment, heat exchanger, and structural member of aircraft. The program also resulted in developing a new fabrication route of thermal spray coating and oxide dispersion strengthened (ODS) iron aluminide composites enabling more precise control over material microstructures.
\end{abstract}




\section{TABLE OF CONTENTS}

SECTION

TITLE

PAGE

FOREWORD

ABSTRACT

TABLE OF CONTENTS

LIST OF FIGURES

LIST OF TABLES

1.0 PROGRAM OBJECTIVES 1

2. 0 INTRODUCTION 1

3.0 EXPERIMENTAL WORK/RESULTS/DICUSSIONS 3

3.1 Powder Coating by CVD Process 6

3.2 Consolidation by CIP/Sinter Method $\quad 7$

3.3 Consolidation By Extrusion 9

$\begin{array}{lll}3.4 & \text { Mechanical Property Testing } & 10\end{array}$

3.5 Thermal Spray Coating 12

$\begin{array}{lll}4.0 & \text { CONCLUSIONS } & 57\end{array}$

$\begin{array}{lll}5.0 & \text { RECOMMENDATIONS } & 58\end{array}$ 


\section{LIST OF FIGURES}

FIGURE

TITLE

PAGE

$1 \quad$ Powdermet's Fluidized Bed Reactor 4

$2 \quad$ Powdermet's Carbonyl Production Unit 5

$3 \quad$ Aluminum and iron coated Iron Powders for thermal spray 6 coating fabricated at Powdermet X520

4 Aluminum and iron coated Iron Powders for thermal spray fabricated at Powdermet X1000

5 Aluminum and Iron coated Iron Powders for thermal spray fabricated at Powdermet X2000

6 Fe, Al Coated Alumina Thermal Spray Powders fabricated at Powdermet

7 Showing alumina reinforced iron aluminide tube fabricated by CIP/sinter process and net shape component by powdermetallurgy technique demonstrated using this CVD coated powder

8 Sintered microstructure of alumina reinforced iron aluminide

$9 \quad$ Aluminum, iron Coated Iron Powders X210

10 Aluminum, iron coated iron powders X1000

11 Optical Micrograph of Extruded (10:1) Iron Aluminide (Atomet Powders) Transverse (200X)

12 Showing Optical Micrograph of Extruded (10:1) Iron Aluminide Longitudinal (200X)

13 Fracture Surface of Extruded (10:1) Iron Aluminide showing mixed mode fracture comprised of brittle and ductile 


\section{LIST OF FIGURES (CONT'D)}

FIGURE

TITLE

PAGE

14 Technical Approach of Thermal Spray Coating on 718 and 304

Substrate

15 SEM Micrograph of Substrate Inconnel $718 \quad$ X160

$16 \quad$ EDS analysis show $\mathrm{Ni}, \mathrm{Fe}, \mathrm{Cr}, \mathrm{Al}$ in inconel 718

17 SEM photomicrograph of as sprayed structure X430

18 SEM micrograph of as sprayed structure X160

19 X ray mapping of Aluminum

$20 \quad$ Xray mapping of Iron

21 EDS analysis of Overlayed Iron-Aluminum

22 EDS Analysis of as sprayed structure show no nickel and chromium from the substrate, which confirm the coverage

23 Polished/Optical micrograph of alumina reinforced iron aluminide plasma sprayed layer

24 Polished/Optical micrograph of alumina reinforced iron aluminide plasma sprayed layer

25 Polished/Optical micrograph of alumina reinforced iron aluminide plasma sprayed layer-show some agglomerates

26 Polished/Optical micrograph of alumina reinforced iron aluminide plasma sprayed layer

27 SEM micrograph of alumina reinforced iron aluminide plasma sprayed structure showing good interface bonding with substrate 


\section{LIST OF FIGURES (CONT'D)}

FIGURE

TITLE

PAGE

28 Plasma Sprayed $\mathrm{Fe}_{3} \mathrm{Al}$ on 304H, coating thickness .009-.0105 inch

X200

29 Plasma Sprayed Alumina reinforced $\mathrm{Fe}_{3} \mathrm{Al}$ on 304H, coating thickness .009-.012 inch X200

30 Plasma Sprayed $\mathrm{Fe}_{3} \mathrm{Al}$ on 718 coating thickness: .0075-.009 inch X200

31 Plasma Sprayed Alumina reinforced $\mathrm{Fe}_{3} \mathrm{Al}$ on 718,coating thickness .006-.008 inch X200

32 HVOF alumina reinforced Fe3Al on 718 - coating thickness $.010 / .011$ inch X200

33 HVOF alumina reinforced Fe3Al on 304 X200 coating thickness $.010 / .011$ inch

$34 \quad \mathrm{HVOF} \mathrm{Fe}_{3} \mathrm{Al}$ on 304 -coating thickness .002 inch X200

35 HVOF Fe3Al on 718 X200 coating thickness .002 inch

$36 \quad \mathrm{Fe}_{3} \mathrm{Al}$ Coating on $304 \mathrm{H}$ substrate after erosion test. Coating remained intact and surface roughness reduced after erosion testX370

$37 \quad$ Fe3Al sprayed coating after Erosion Test X700

$38 \quad$ EDS analysis show alumina reinforced iron aluminide coating

39 SEM micrograph showing alumina reinforced $\mathrm{Fe}_{3} \mathrm{Al}$ coating after erosion test showing eroded more than X370 


\section{LIST OF FIGURES (CONT'D)}

FIGURE

TITLE

PAGE

$40 \quad$ Alumina reinforced $\mathrm{Fe}_{3} \mathrm{Al}$ after erosion test $\mathrm{X1400}$

41 EDS analysis showing that alumina reinforced iron aluminide coating

42 Showing Thermal Sprayed Exposed, other faces are covered in Alumina

43 Side view show Thermal Sprayed Sample one face is open for exposure, other faces are covered in Alumina

44 Side view show Thermal Sprayed Sample one face is exposed, other faces are covered in Alumina

$45 \quad$ Free carbon deposited on samples

46 Uncoated and thermal sprayed Samples after Carburization tests

$47 \quad$ Showing free carbon accumulated on tested sample

48 Showing Samples after Corrosion Tests in presence of $\mathrm{Fe}_{2} \mathrm{O}_{3}-37.5$ wt\% $\mathrm{Na}_{2} \mathrm{SO}_{4}-37.5 \mathrm{wt}^{\circ} \mathrm{K}_{2} \mathrm{SO}_{4}$ for 100 Hours at $1000{ }^{\circ} \mathrm{C}$

49 Showing thermal sprayed alumina reinforced $\mathrm{Fe}_{3} \mathrm{Al}$ and $\mathrm{Fe}_{3} \mathrm{Al}$ $304 \mathrm{H}$ partially attacked by this $\mathrm{Fe}_{2} \mathrm{O}_{3}, \mathrm{~K}_{2} \mathrm{SO}_{4}, \mathrm{Na}_{2} \mathrm{SO}_{4}$ but alumina reinforced $\mathrm{Fe}_{3} \mathrm{Al}$ showed better property.

50 Showing uncoated $304 \mathrm{H}$ severely attacked by this $\mathrm{Fe}_{2} \mathrm{O}_{3}, \mathrm{~K}_{2} \mathrm{SO}_{4}$, $\mathrm{Na}_{2} \mathrm{SO}_{4}$

51 SEM micrograph showing uncoated $304 \mathrm{H}$ is corroded and layer is falling off

52 EDS analysis Showing under the corroded layer is comprised of iron and chromium $\mathbf{- 3 0 4 H}$ 


\section{LIST OF FIGURES (CONT'D)}

\section{TITLE}

PAGE

53 Showing that uncoated $304 \mathrm{H}$ surface was attacked by $\mathrm{K}_{2} \mathrm{SO}_{4}$ and $\mathrm{Na}_{2} \mathrm{SO}_{4}$

54 Showing that uncoated $304 \mathrm{H}$ surface was attacked by $\mathrm{K}_{2} \mathrm{SO}_{4}$ and $\mathrm{Na}_{2} \mathrm{SO}_{4}$

55 Showing thermal sprayed alumina reinforced $\mathrm{Fe}_{3} \mathrm{Al}$ on $304 \mathrm{H}$ partially attacked by this $\mathrm{Fe}_{2} \mathrm{O}_{3}, \mathrm{~K}_{2} \mathrm{SO}_{4}, \mathrm{Na}_{2} \mathrm{SO}_{4}$ but coating remains intact and underneath layer was not attacked

55A Showing thermal sprayed alumina reinforced $\mathrm{Fe}_{3} \mathrm{Al}$ on $304 \mathrm{H}$ partially attacked by this $\mathrm{Fe}_{2} \mathrm{O}_{3}, \mathrm{~K}_{2} \mathrm{SO}_{4}, \mathrm{Na}_{2} \mathrm{SO}_{4}$ but coating remains intact and underneath layer was not attacked EDS analysis showing only $\mathrm{Fe}, \mathrm{Cr}$

56 Showing alumina reinforced $\mathrm{Fe}_{3} \mathrm{Al}$ Sprayed, $\mathrm{Fe}_{3} \mathrm{Al}$ sprayed $304 \mathrm{H}$, IN718, uncoated 718, $304 \mathrm{H}$ and mild steel Samples after Oxidation Test

57 Showing Alumina Reinforced $\mathrm{Fe}_{3} \mathrm{Al}$ Sprayed coating is lighter in color than $\mathrm{Fe}_{3} \mathrm{Al}$ Sprayed Samples after Cyclic Oxidation Tests. Weight gain is less incase of alumina reinforced thermal sprayed $\mathrm{Fe}_{3} \mathrm{Al}$ coating. But coating remained intact after oxidation tests for both $\mathrm{Fe}_{3} \mathrm{Al}$ coating and alumina reinforced $\mathrm{Fe}_{3} \mathrm{Al}$ coating

58 SEM Micrograph showing morphology of as sprayed $\mathrm{Fe}_{3} \mathrm{Al}$ coating on 304 H X150

59 EDS analysis show $\mathrm{Fe}$ and $\mathrm{Al}$ from $\mathrm{Fe}_{3} \mathrm{Al}$. $\mathrm{Cr}$ is from original powders

60 SEM Micrograph of $\mathrm{Fe}_{3} \mathrm{Al}$ sprayed on $304 \mathrm{H}$ after the cyclic oxidation test. Figure show some change in morphology but coating showed enough adhesion to protect underneath substrate X150

61 SEM Micrograph of $\mathrm{Fe}_{3} \mathrm{Al}$ sprayed on $304 \mathrm{H}$ after the cyclic oxidation test.Figure show some change in morphology but coating showed enough adhesion to protect underneath substrate X150 


\section{LIST OF FIGURES (CONT'D)}

FIGURE

TITLE

PAGE

62 Top oxidized layers were removed underneath oxidized layer showing same morphology like before the test X150

63 Showing Oxidized layers were removed under the top layer X800

64 EDS analysis represent $\mathrm{Fe}_{3} \mathrm{Al}$ Coating protecting underneath substrate

65 Cross section of the coating represent 10-20 micron thermal sprayed layers were oxidized after cyclic oxidation test but remaining thermal sprayed layer was not attacked and protecting 304H substrate

66 EDS analysis of coating after the oxidation test show Fe, Al, $\mathrm{Cr}$ which similar to before oxidation

67 EDS analysis showing only Fe and $\mathrm{Cr}$ in the $304 \mathrm{H}$ substrate.

68 Alumina reinforced iron aluminide coating on $304 \mathrm{H}$ after oxidation test $\mathrm{X} 150$

69 Alumina reinforced iron aluminide coating on $304 \mathrm{H}$ after oxidation test X350

70 SEM micrograph of Alumina reinforced iron aluminide coating on 304H after cyclic oxidation, Showing alumina particles are still nicely bonded with Fe3Al matrix for protecting substrate

$71 \quad$ EDS analysis of $\mathbf{3 0 4} \mathrm{H}$ substrate

$72 \quad 100$ micron oxide layer X140

$73 \quad$ EDS analysis showing alumina reinforced $\mathrm{Fe}_{3} \mathrm{Al}$ coating 


\section{LIST OF FIGURES (CONT'D)}

FIGURE

TITLE

PAGE

$74 \quad$ EDS analysis of alumina particles in $\mathrm{Fe}_{3} \mathrm{Al}-$ after oxidation

75 EDS Analysis showing that alumina particles are nicely bonded with iron aluminide matrix even after cyclic oxidation test

76 EDS analysis of Fe3Al matrix area of alumina reinforced Fe3Al coating

$77 \quad$ EDS analysis of alumina reinforced iron aluminide coating

78 Show coating was not delaminated after cyclic oxidation. Alumina reinforced iron aluminide protected underneath substrate . Here EDS analysis showing the analysis of $304 \mathrm{H}$ substrate

79 EDS analysis Showing Iron aluminide coating after cyclic oxidation

80 Uncoated $304 \mathrm{H}$ after cyclic oxidation test show oxide layers falling off while polishing X350

81 Showing uncoated $304 \mathrm{H}$ after oxidation - Oxide layer spalling off and substrate was attacked by this cylic oxidation- show oxidation X700

82 EDS analysis represent the layer is comprised of oxides of iron and chromium

83 EDS analysis of $304 \mathrm{H}$ substrate after cyclic Oxidation test 
LIST OF TABLES

TABLE

TITLE

PAGE

$1 \quad$ CVD Coating Run Summary 5

$2 \quad$ Mechanical Properties of Extruded Bars $\quad 11$

$3 \quad$ Layer Thicknesses of Iron Aluminide Coating 13

$4 \quad$ Plasma Sprayed $\mathrm{Fe}_{3} \mathrm{Al}$ and Alumina reinforced $\mathrm{Fe}_{3} \mathrm{Al}$ Coating on 20

718 and $304 \mathrm{H}$ substrate

5 HVOF Sprayed $\mathrm{Fe}_{3} \mathrm{Al}$ and Alumina reinforced $\mathrm{Fe}_{3} \mathrm{Al}$ Coating on IN 23

718 and $304 \mathrm{H}$ substrate

$6 \quad$ Hardness of Plasma sprayed Alumina Reinforced $\mathrm{Fe}_{3} \mathrm{Al}$ on 718

$7 \quad$ Hardness of Plasma Sprayed $\mathrm{Fe}_{3} \mathrm{Al}$ on 718

8 Hardness of Plasma Sprayed Oxide reinforced Fe3Al coating on 26 304H

$9 \quad$ Hardness of Plasma Sprayed Fe3Al coating on 304H 27

$10 \quad$ Hardness of HVOF sprayed Alumina Reinforced Fe $\mathrm{Al}_{3} \mathrm{Al}$ on 718

$11 \quad$ Hardness of HVOF Sprayed $\mathrm{Fe}_{3} \mathrm{Al}$ on 718

12 Hardness of HVOF Sprayed Oxide reinforced Fe3Al coating on 28 304H

13 Hardness of HVOF Sprayed $\mathrm{Fe}_{3} \mathrm{Al}$ coating on $304 \mathrm{H}$ 


\section{LIST OF TABLES (CONT'D)}

TABLE

TITLE

PAGE

14 Erosion Test Results of Plasma Spray and HVOF sprayed Fe3Al

29 and Alumina Reinforced Fe3Al on IN 718 and 304H Substrate

15 Carburization Test Results of Fe3Al and Alumina Reinforced 35 Fe3Al Coating on 304H and IN 718 Substrate

16 Corrosion Test Results of Fe3Al and Alumina Reinforced Fe3Al Coating on 304H and IN 718 Substrate

17 Oxidation Test Results of Fe3Al and Alumina Reinforced Fe3Al 56 Coating on 304H and IN 718 Substrate 


\subsection{PROGRAM OBJECTIVES}

The objective of this program for Powdermet was to fabricate and evaluate key mechanical and physical properties of iron aluminide composite fabricated by cold isostatic preseed (CIP) /sinter, CIP/extrusion and thermal sprayed coating process with the objective of examining the potential for use of such material in the construction of certain power generation components, such as boiler tubes, thermal sprayed coating to enhance life and performance of Coal-Fired Boilers components such as fire side corrosion on the OD of the water wall and superheater tubing as well as on the ID and OD of larger diameter headers. In executing this task it should be recognized that with the Powdermet aluminide coating and its composites being a new material whose processing has partially optimized but not fully optimized, more than one processing iteration and pathway or method had to be evaluated, while keeping in mind downstream considerations such as scale-up, property balance, temperature tolerance, etc. This evaluation may therefore be considered as an initial evaluation aimed at guiding the path towards further optimization and technology maturation of innovative ODS iron aluminide composite, iron aluminide, alumina reinforced iron aluminide and it's coating to unique applications for future power generation structures.

\section{0: INTRODUCTION}

The high efficiency power plant of the $21^{\text {st }}$ century will consist of a pressurized fluidized bed (PFB), combined cycle (CC) power plant, or an integrated gasification combined cycle (IGCC). These PFB/CC and IGCC systems burn high sulfur coal in an environmentally acceptable way more efficiently than any other coal burning systems currently under development. However, operation and efficiencies of PFB and other combined cycle power generation systems are limited by one or more of the following factors:

Combustor and heat exchanger designs

Temperature limits on piping, as well as non-uniformity and "hot spots" created in the bed and tube bundles limit operating temperatures. This is particularly true of superheater and preheater bundles.

Low gas turbine inlet temperatures

$\mathrm{PFB}$ exit temperatures are limited to $1500-1700^{\circ} \mathrm{F}$, largely due to gas cleanup, sulfur removal, and piping limitations. More advanced designs will use a topping cycle to increase gas turbine inlet temperatures to $2300^{\circ} \mathrm{F}$

Non-optimum steam conditions

Increasing steam temperatures and pressures improved efficiency of the steam turbine cycle. Current systems operate at steam temperatures of $550^{\circ} \mathrm{C}\left(1032^{\circ} \mathrm{F}\right)$. Next generation systems will operate at $650-700^{\circ} \mathrm{C}$ $\left(1202-1292^{\circ} \mathrm{F}\right)$, and design goals now call for 750-850 degree $\mathrm{C}$ (1382- 
$1562^{\circ} \mathrm{F}$ ) steam temperatures. These increased temperatures will be generated in superheaters and reheaters in both low emission boilers, PFB's, and firetube boilers built into IGCC's. This will push power cycle efficiencies to over $50 \%$ in combined cycle plants.

These limitations are all related to availability of oxidation and corrosion resistant materials are capable of withstanding temperatures of $1300-1700^{\circ} \mathrm{F}\left(705-927^{\circ} \mathrm{C}\right)-$ well above the temperature limits of currently affordable materials. Iron aluminides offer a potential solution to materials challenges for these next generation (and retrofit) fossil fuel powered utility power islands. Iron aluminides have the following unique properties, making them ideal for use in $1100-1700^{\circ} \mathrm{F}$ temperature regimes:

Low cost compared to cobalt- and nickel-based superalloys

$>$ Excellent oxidation resistance

$>$ Good hot corrosion/sulphidation resistance (intermediate $\mathrm{Cr}$ alloys)

$>$ Excellent carburization resistance (low to intermediate $\mathrm{Cr}$ alloys)

$>$ High yield and creep strengths at elevated temperatures

$>$ Acceptable toughness and ductility at low temperatures

Drawbacks of current iron aluminides include the following:

$>$ Poorer than desired material ductilities

$>$ Limited availability, processing capabilities and field exposure experience

$>$ Lower than desired creep resistance and high temperature strength

$>$ Poor weldability

Lack of approved minimum design property values (ASTM Boiler Code)

IGCC conditions are typically consist of:

$>$ Gasification temperature: $2300-2500^{\circ} \mathrm{F}$

$>$ Syngas exit temperature (Wabash): $1900^{\circ} \mathrm{F}$

$>$ Syngas cooler steam generator (Wabash): 1600psig

Hot gas cleanup gas temperature: $800-1100^{\circ} \mathrm{F}$

Typical conditions encountered in PFBC and integrated gasification combined cycle (IGCC) systems are described as follows:

$>$ The gas environment in a PFBC system is an oxidizing combustion stream, with an operating temperature in the range of $840-950^{\circ} \mathrm{C}\left(1544-1742^{\circ} \mathrm{F}\right)$

$>$ Operating pressures are typically 10-16atm.

$>$ Ash particle loadings may range from 500 to $10,000 \mathrm{ppm}$ by weight

$>$ The system contains volatile chloride, sulfur, and alkali species 


\section{Materials Needs}

Based on projected operating conditions in future utility generating systems, the following components would tremendously benefit from advanced materials use:

$>$ Carbonizer/synfuel cooler heat exchanger tubes $\left(1500-1900^{\circ} \mathrm{F}\right.$; reducing/carburizing atmosphere containing $\mathrm{H}_{2}$ and $\mathrm{H}_{2} \mathrm{~S}$ )

Hot gas filters $\left(1100-1500^{\circ} \mathrm{F}\right.$; can be oxidizing or reducing)

$>$ Superheater and reheater tubes $\left(1100-1500^{\circ} \mathrm{F}\right.$; oxidizing

$>$ Thermocouple sheaths, injectors, clamps, valves, supports, fasteners, ferrules, and other components

Two primary approaches exist to solving these materials problems:

(1) Developing improved coatings that enable current materials such as nickel-based alloys and stainless steels to be used in these highly oxidizing and/or corrosive environments.

(2) Developing new alloys with improved high temperature strength and corrosion resistance.

Iron aluminide materials based on $\mathrm{Fe}_{3} \mathrm{Al}$ and $\mathrm{FeAl}$ compositions show potential for use in all of the above-mentioned components as both coatings and as new alloys (given improvements in material compositions/microstructures and processing/fabrication capabilities).

\section{0: EXPERIMENTAL WORK, RESULTS AND DISCUSSIONS:}

The initial target was to coat the iron powders or alumina particles with a thin layer of iron, followed by a thin layer of aluminum and aluminum oxide, such that these would produce an ODS iron aluminide alloy or alumina reinforced iron aluminide after the consolidation step. The scope was expanded to include two more alloy additions for this study - chromium and boron to increase room temperature ductility and grain boundary strength. But it was realized that chromium and boron coating by CVD process is not a cost effective process. As a result iron-chromium initial powder was chosen for coating of iron, aluminum and incase of iron, aluminum coated alumina powders, no chromium was blended before consolidation step or thermal spray deposition.

A critical technical repeatability and reproducibility issues were demonstrated applying uniform, nanoscale, CVD oxide coatings with aluminum, iron, having controlled morphology. To accomplish this, deposition studies were conducted on aluminum, iron, chromium and boron coating systems. Though chromium and boron were not deposited on the final powders due to cost issue, Powdermet did experimental/developmental run for chromium and boron deposition.

The iron coatings were deposited using standard carbonyl precursor materials. Iron 
pentacarbonyl was used as the starting precursor. Iron deposition was performed in a small bed reactor, where the particles were fluidized and then CVD coated with the desired amount of iron via the following reaction:

$$
\mathrm{Fe}(\mathrm{CO})_{5} \rightarrow \mathrm{Fe}+5 \mathrm{CO}
$$

Iron pentacarbonyl was directly fed to the reactor as liquid and vaporized at $200{ }^{\circ} \mathrm{C}$

Iron deposition was subsequently followed by CVD deposition of aluminum onto the iron surface. Aluminum deposition was done using tri-ethylene aluminum (TEAL) decomposition at $460-475^{\circ} \mathrm{C}$. The key difficulty with aluminum deposition from TEAL was obtaining high density nucleation, and TEAL was vaporized $\left(175^{\circ} \mathrm{C}\right)$ before entering the reactor. However, at the end of the program nucleation problems were solved within this short period of the program.

Tri-ethylene aluminum $\left(\mathrm{TEAL} / \mathrm{H}_{2} \mathrm{O}\right)$ were selected as suitable precursors for alumina, and deposition investigations were conducted. Deposition investigations included temperature, pressure and partial pressure effects on oxide deposition. Alumina deposition results indicated that alumina could be successfully deposited from TEAL.

Aluminum, iron, alumina encapsulation was conducted on iron-chromium alloy powders and aluminum, iron encapsulation were done on alumina particles using Powdermet, Inc.'s patented, R\&D 100 award winning (2000) Recirculating Fast-fluidized Bed (RFFB), as shown in Figure 1. Then iron was deposited via chemical vapor deposition from iron carbonyl onto fluidized iron-chromium and alumina powders. The iron carbonyl was vaporized in the reactor and iron-chromium alloy powders were fluidized using argon/hydrogen gas flow. $\mathrm{Fe}-\mathrm{Cr}$ was produced according to the following reaction:

$$
\mathrm{Fe}(\mathrm{CO})_{5} \rightarrow \mathrm{Fe}+5 \mathrm{CO} \uparrow\left(200-250^{\circ} \mathrm{C}\right)
$$

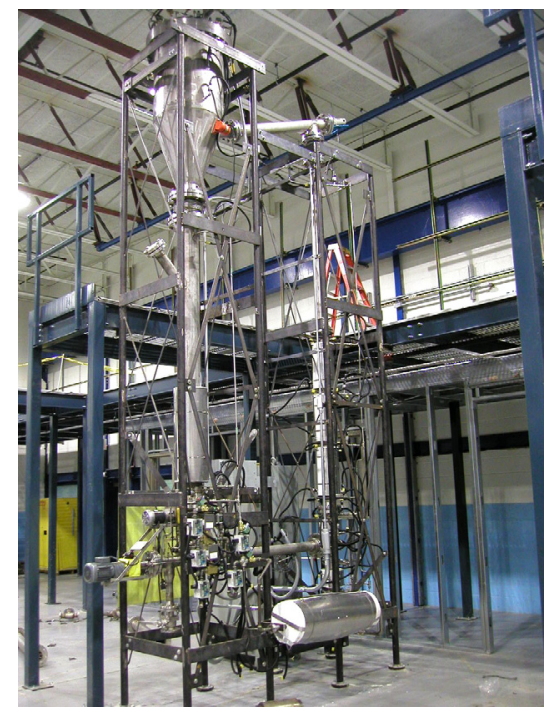

Figure 1. Powdermet's Fluidized Bed Reactor 
Aluminum and aluminum oxide, was coated onto $\mathrm{Fe}-\mathrm{Cr}$ alloy powders according to following reactions:

$$
\begin{gathered}
\mathrm{TEAL} \rightarrow \mathrm{Al}+3\left(\mathrm{C}_{2} \mathrm{H}_{5}\right)\left(460-475^{\circ} \mathrm{C}\right) \\
\mathrm{Al}+\mathrm{H}_{2} \mathrm{O} / \mathrm{H}_{2} \rightarrow \rightarrow \quad \mathrm{Al}_{2} \mathrm{O}_{3}\left(250-350^{\circ} \mathrm{C}\right) \\
\mathrm{Al}\left(\mathrm{C}_{2} \mathrm{H}_{5}\right)_{3}(\mathrm{TEAL})+\mathrm{H}_{2} \mathrm{O} \rightarrow \mathrm{Al}_{2} \mathrm{O}_{3}+\text { Byproducts }
\end{gathered}
$$

Similarly iron and aluminum was coated on fluidized alumina particles.

Powdermet uses metal salts, alkyls and carbonyls to produce coated powders. For metal carbonyls (Mond Process used in nickel refining), Powdermet has vertically integrated to manufacture its own precursors for cost-effective manufacture of coated powders. Figure 2 shows a carbonyl production unit installed at Powdermet's Euclid, Ohio manufacturing plant. Coating summary is presented in Table 1

Table 1. CVD Coating Run Summary

\begin{tabular}{|l|l|c|c|c|c|}
\hline Precursor & $\begin{array}{l}\text { Temp. } \\
\text { Ranges }\end{array}$ & $\begin{array}{c}\text { Theoretical } \\
\text { Yield (\%) }\end{array}$ & $\begin{array}{c}\text { Actual } \\
\text { Yield } \\
\mathbf{( \% )}\end{array}$ & Comments & $\begin{array}{c}\text { Pressure } \\
\text { (in hg) }\end{array}$ \\
\hline $\begin{array}{l}\text { TEAL (for } \mathrm{Al} \\
\text { deposition) }\end{array}$ & $250-300^{\circ} \mathrm{C}$ & $23.7 \%$ & $19.5-20 \%$ & Oxygen control & -25 \\
\hline $\begin{array}{l}\mathrm{TEAL} / \mathrm{H}_{2} \mathrm{O} \\
\text { (for alumina) }\end{array}$ & $200-350^{\circ} \mathrm{C}$ & 25 & 22.0 & $\mathrm{H}_{2} \mathrm{O} / \mathrm{H}_{2}$ & -20 to -25 \\
\hline $\begin{array}{l}\text { Iron Carbonyl } \\
\text { (for iron) }\end{array}$ & $175-200^{\circ} \mathrm{C}$ & 28.6 & 25.0 & $\begin{array}{l}\text { Carbon/oxygen } \\
\text { Control }\end{array}$ & -20 to -25 \\
\hline $\begin{array}{l}\text { Diborane } \\
\text { (for boron) }\end{array}$ & $500-600^{\circ} \mathrm{C}$ & 79 & 55.0 & $\begin{array}{c}\text { Boron } \\
\text { concentration }\end{array}$ & -20 to -25 \\
\hline $\begin{array}{l}\text { Chromium } \\
\text { Carbonyl (for } \\
\text { chromium) }\end{array}$ & $350-500^{\circ} \mathrm{C}$ & 23 & 20.0 & $\begin{array}{l}\text { Oxygen/carbon } \\
\text { Control }\end{array}$ & -25 \\
\hline
\end{tabular}

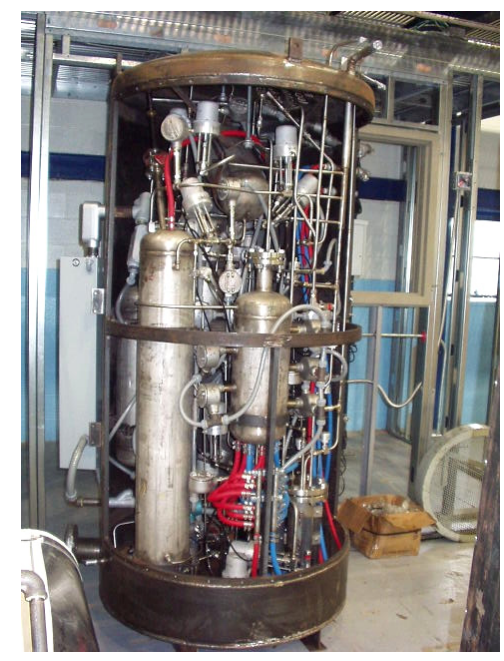

Figure 2. Powdermet's Carbonyl Production Unit 
3.1 Powder Coating: 5-20 micron iron-chromium powders and 30 micron size alumina particles were coated with iron/aluminum/alumina and iron/aluminum. Figures 3-6 are a SEM photomicrograph of the powders.

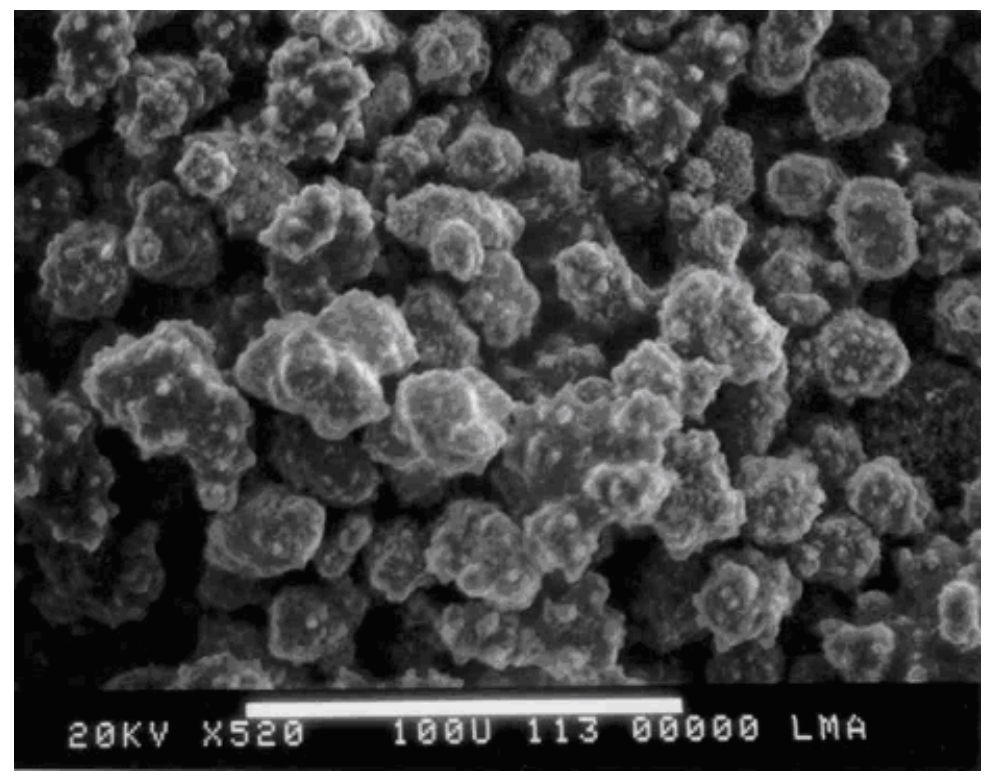

Figure 3: Aluminum and iron coated Iron Powders for thermal spray coating fabricated at Powdermet X520

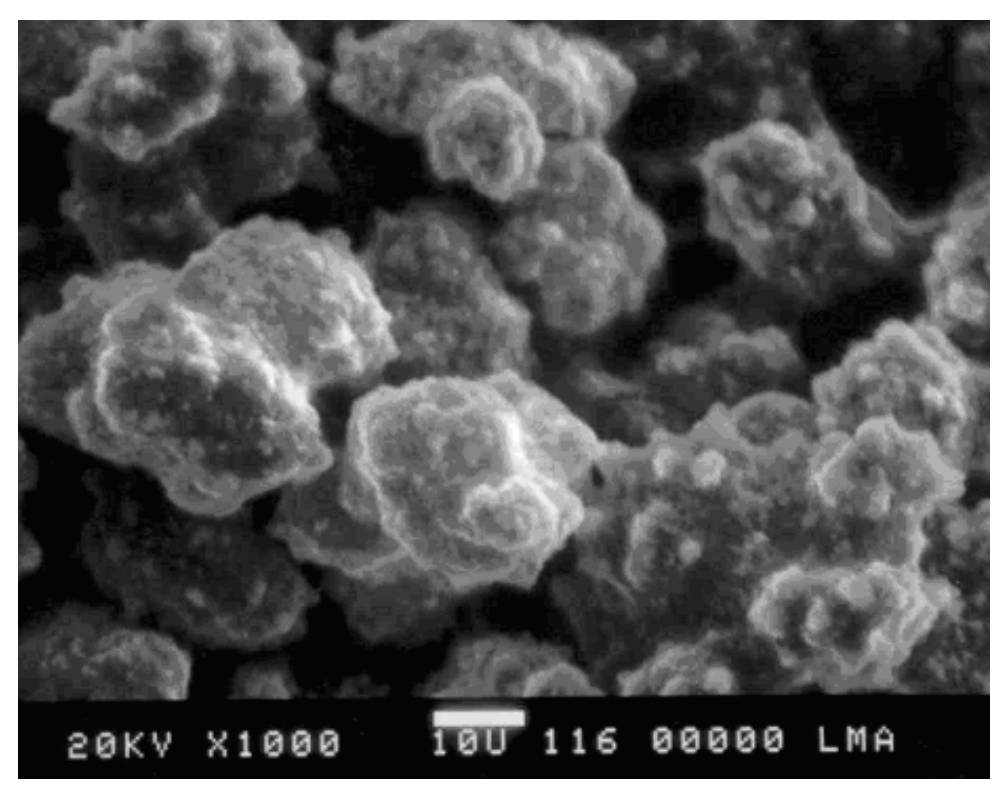

Figure 4: Aluminum and iron coated Iron Powders for thermal spray fabricated at Powdermet X1000 


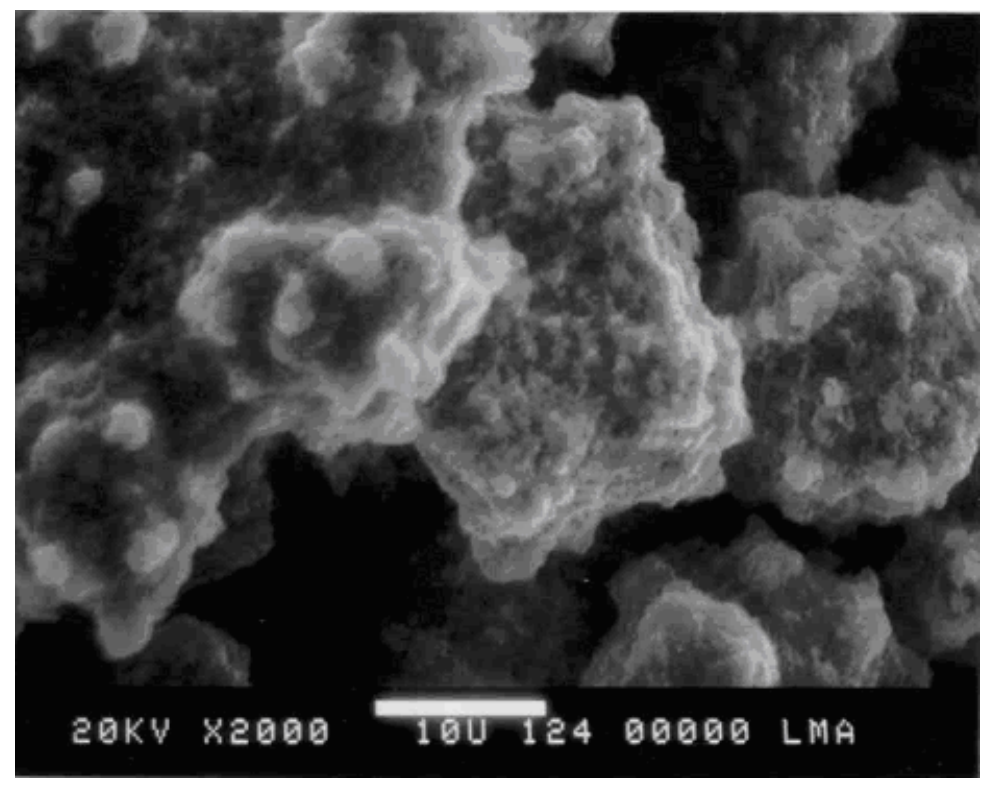

Figure 5: Aluminum and Iron coated Iron Powders for thermal spray fabricated at Powdermet X2000

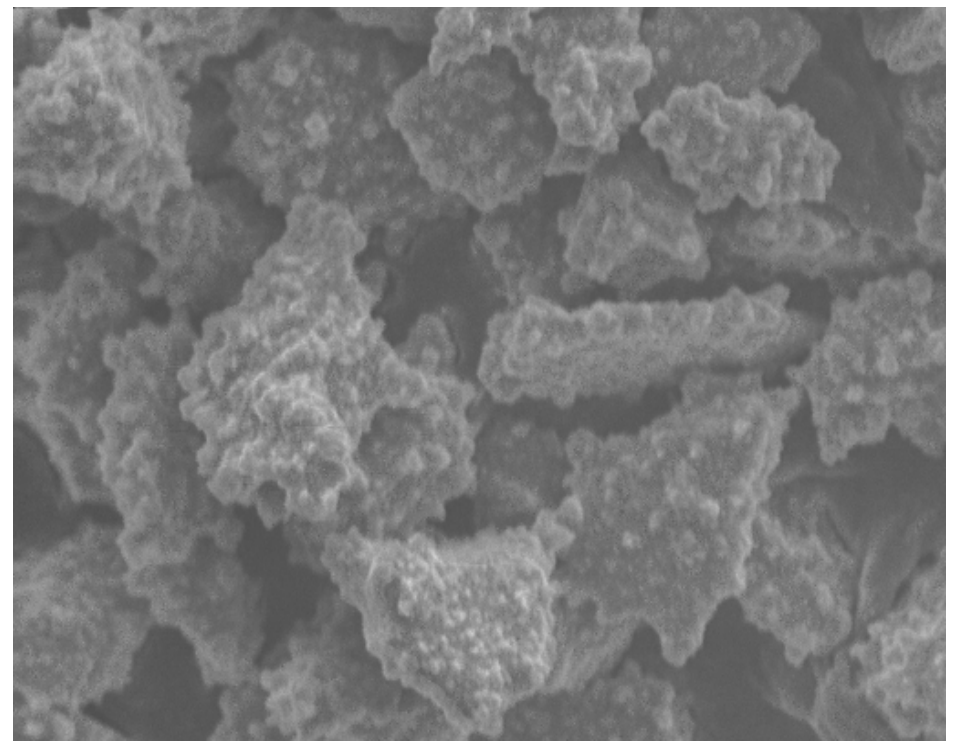

Figure 6: Fe, Al Coated Alumina Thermal Spray Powders fabricated at Powdermet

This is the one of the biggest achievement of the program that Powdermet successfully fabricated CVD iron, aluminum, aluminum oxide coated iron and iron, aluminum coated alumina powders for fabricating composites and thermal spray coating for future power generation equipment.

\subsection{Consolidation by CIP/Sinter Method}

Mechanically pressed powders from small coupons were placed into a furnace and were 
evacuated prior to heating. The samples were heated to $200^{\circ} \mathrm{C}$ and held for 1 hour to remove adsorbed moisture. The furnace ramped up to the sintering temperature (800$1300^{\circ} \mathrm{C}$ ) for 1-4 hours. To develop the sintering process, coated powders were compacted into pellets and sintered in a vacuum at $1300^{\circ} \mathrm{C}$ for 1 hour. Inspecting the sintered microstructures revealed that sintered samples fabricated by aluminum coated iron iron powders showed better densification and microstructure than the sample fabricated by aluminum/aluminum oxide coated and iron, aluminum coated alumina powders. The $1300^{\circ} \mathrm{C}, 1$ hour sintering samples sintered the best.

Powdermet demonstrated netshape fabrication of tube by powder metallurgy technique. and Figures 8 represent sintered microstructures of the alumina reinforced iron aluminide

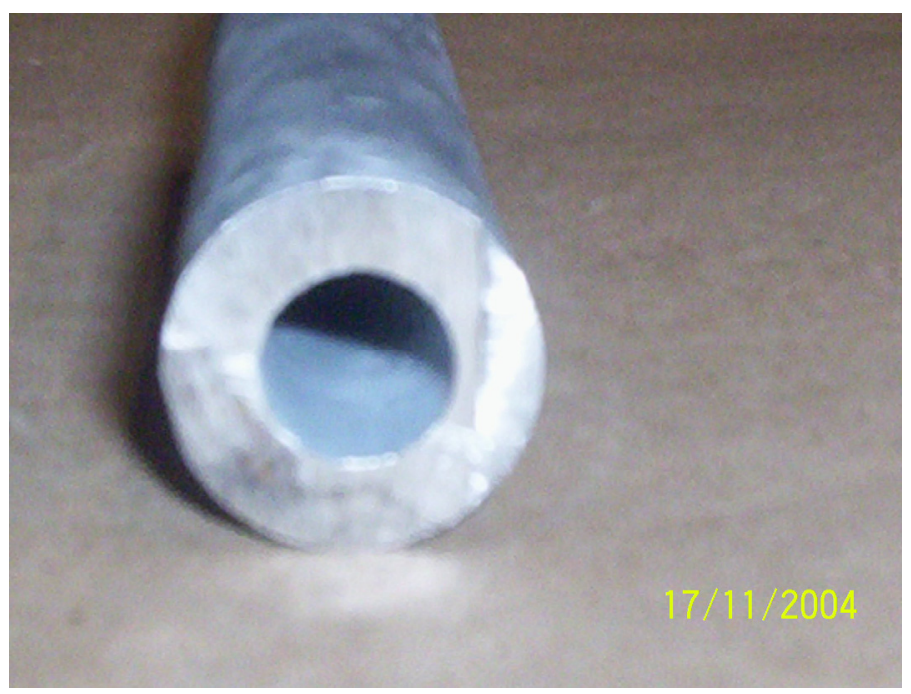

Figure 7: Showing alumina reinforced iron aluminide tube fabricated by CIP/sinter process and net shape component by powdermetallurgy technique demonstrated using this CVD coated powder

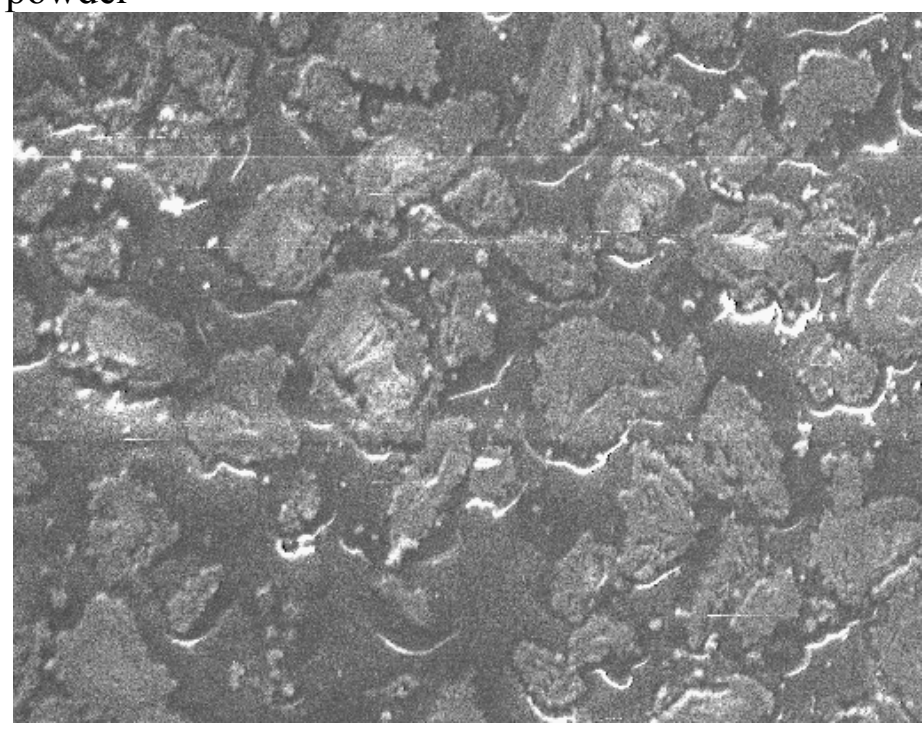

Figure 8: Sintered microstructure of alumina reinforced iron aluminide 
3.3 Consolidation By Extrusion: Powders shown in figure 9 and 10 were coated with iron, aluminum and aluminum oxide on iron and then cold isostatically pressed and extruded. No rolling was done after extrusion. Extrusion of canned and evacuated cold isostatically pressed bars was done at $1000{ }^{\circ} \mathrm{C}$ at a $10: 1$ extrusion ratio. At first bars with Fe-16Al composition were cold isostatically pressed at a pressure of $60,000 \mathrm{psi}$, canned in mild steel and evacuated. Extrusion conditions produced a fully dense product. Extruded bars were cut into pieces and the steel cans were removed from the extruded bars. Tensile testing specimens were machined from the can-free extruded ODS iron aluminide bars. Figure to Figure represent CVD aluminum coated iron powders.

Optical micrographs of transverse and longitudinal sections of extruded ODS iron aluminide bars are presented in Figures 11 and 12.
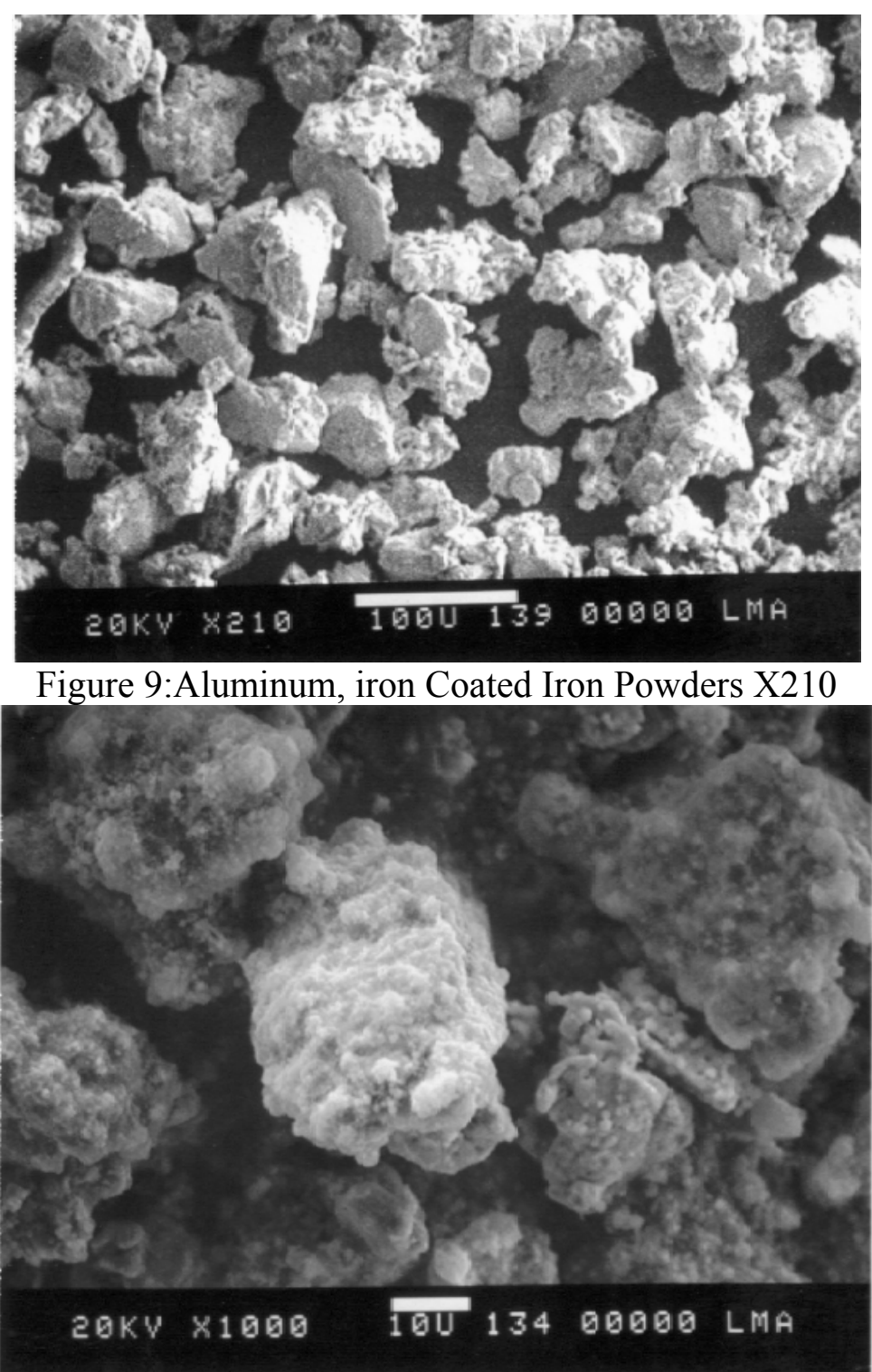

Figure 10: Aluminum, iron coated iron powders X1000 
Figures 11 and 12 represent optical micrographs of transverse and longitudinal sections of extruded ODS iron aluminide bars.

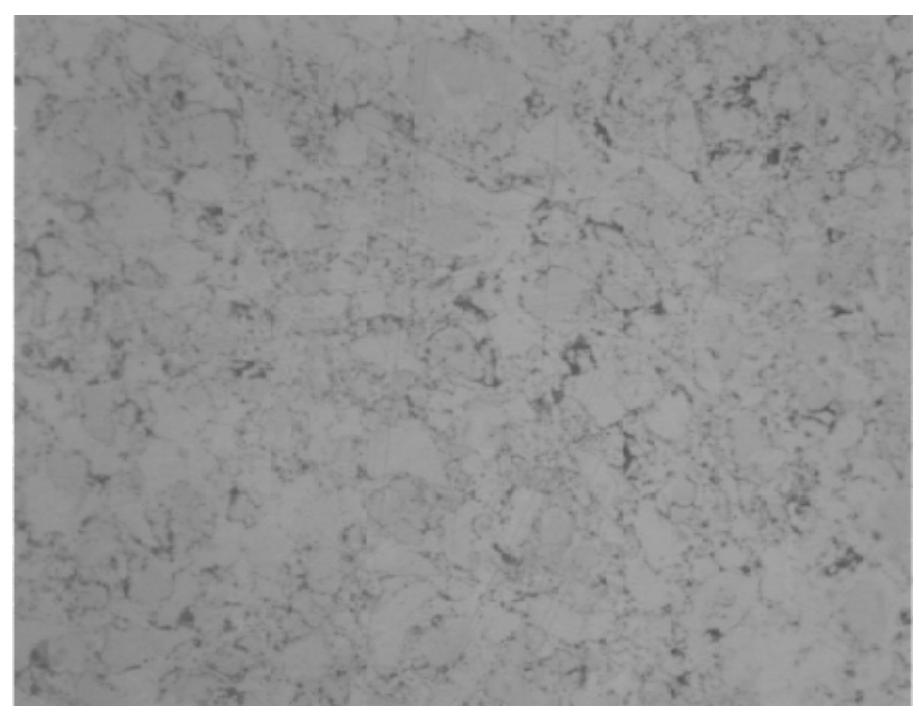

Figure 11. Optical Micrograph of Extruded (10:1) Iron Aluminide Transverse (200X)

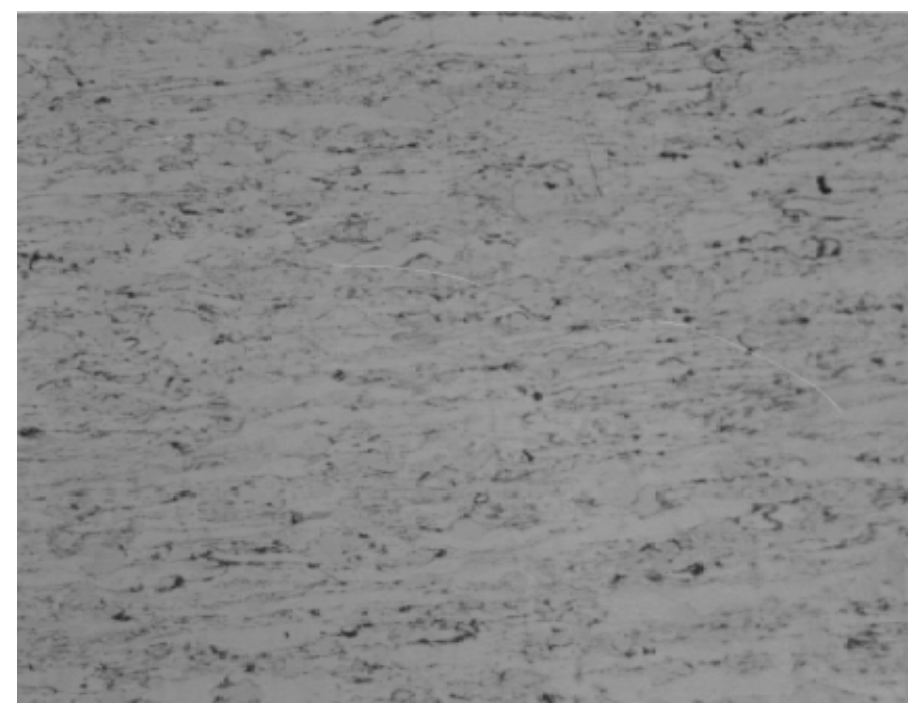

Figure 12. Showing Optical Micrograph of Extruded (10:1) Iron Aluminide Longitudinal (200X)

\subsection{Mechanical Property Testing}

For ODS iron aluminide, tensile testing was conducted only at room temperature and only few tests were performed due to difficulty in machining samples. Samples were breaking frequently during fabricating tensile test samples. Samples were breaking in the threaded neck region of ODS iron aluminide during tensile test sample fabrication. As a 
result, not many tensile samples were fabricated and tested. Same thing happened in a previous program.

Despite this problem, a few tensile tests were performed at room temperature for ODS iron aluminide. Table 2 represents extruded ODS iron aluminide mechanical test results.

Table 2. Mechanical Properties of Extruded Bars

\begin{tabular}{|l|l|l|l|l|}
\hline $\begin{array}{l}\text { Particle } \\
\text { Size }\end{array}$ & $\begin{array}{l}\text { Test } \\
\text { Temperature }\end{array}$ & $\begin{array}{l}\text { Yield Strength, } \\
\text { KSI }\end{array}$ & Elongation (\%) & $\begin{array}{l}\text { ULT } \\
\text { KSI }\end{array}$ \\
\hline 40 Micron & RT & 105 & 4.1 & 118 \\
\hline & RT & 104 & 3.7 & 121 \\
\hline & RT & - & $\begin{array}{l}\text { Specimen } \\
\text { fractured }\end{array}$ & 101 \\
\hline
\end{tabular}

The ultimate tensile strength (UTS) of the extruded ODS iron aluminide alloy was 101$121 \mathrm{KSI}$. The UTS of MA 754 is $140 \mathrm{KSI}$ with yield strength of $85 \mathrm{KSI}$. Yield strength and UTS of MA 758 are $81 \mathrm{KSI}$ and 138KSI, respectively. The MA 956 alloy posses 75 KSI yield strength and 95KSI UTS. Comparing these mechanical property data, it can be concluded that mechanical properties obtained in this study of ODS iron aluminide using the CVD coated powder approach shows potential.

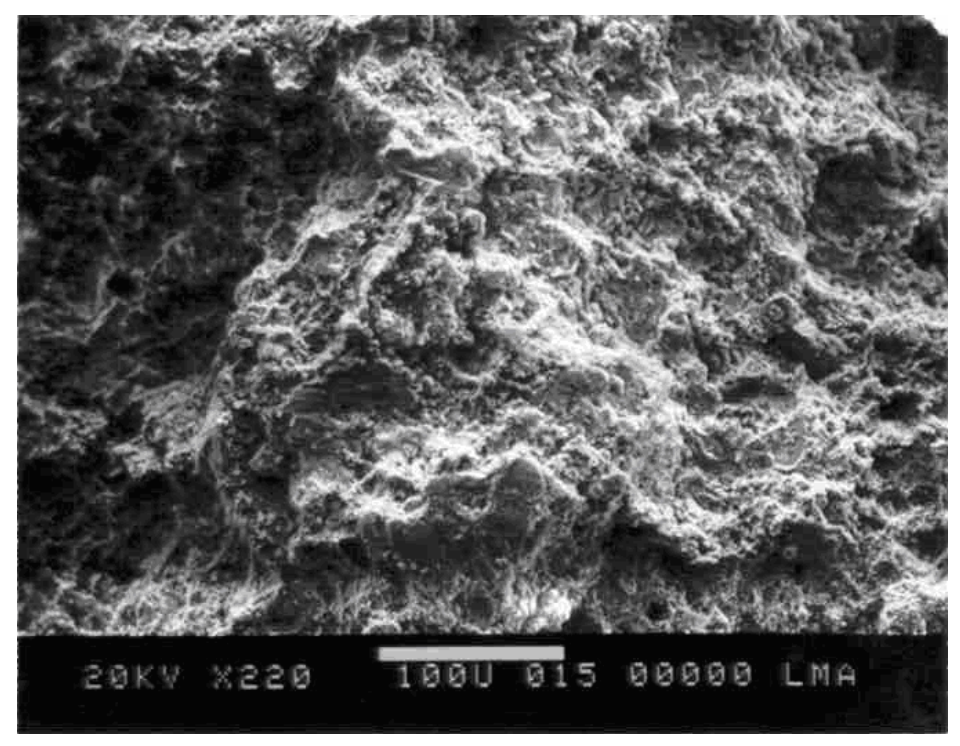

Figure 13. Fracture Surface of Extruded (10:1) Iron Aluminide showing mixed mode fracture comprised of brittle and ductile

But a limited attention was given to $\mathrm{CIP} /$ extrusion consolidation process before it was abandoned due to poor room temperature properties, breaking of samples while machining, needed for room temperature property modifications, further consolidation development and financial need. In a previous program almost same results were obtained. So with the permission of DOE I \&I HQ Technology Manager, Project Officer 
and that time Project Monitor, the CIP/extrusion or CIP/sinter process route had to be sacrificed (at the program outset) for the more critical processing-microstructure-property optimization effort and the more readily available thermal spray coating method using this powder for oxidation, carburization and sulfidation coating.

\subsection{Thermal Spray Coating:}

\section{Thermal spray deposition}

Thermal spraying is a well-established process for fabricating freestanding structures from a wide range of metals, alloys and ceramic materials. It is a complex process involving rapid melting and high velocity impact deposition of melted powder droplets usually referred as "splats." Due to the rapid solidification or quenching of materials, the coating evolution process is also complex; usually leading to fine-grained and metastable microstructure of deposited materials. A unique feature of thermal spraying is that it combines melting, quenching, and consolidation in to a single operation and therefore retains the rapidly quenched structure of materials.

These splats form the "building blocks" of the coatings, and the conditions of these splats prior to impact on the substrate - namely, their temperature, velocity, size and also properties of the substrates such as temperature, chemistry and roughness - determine the droplets' spreading or flatness and rate of solidification. Depending upon these factors, the resulting splats form different shapes, thickness and adhesion to the substrates with important consequences on the coating microstructure and on other physical and mechanical properties. It must be noted that thermal spray is a "line of sight" process where the arriving droplets from which the coating is formed deposit only on to the surfaces that are directly in line with the droplets direction. Due to the high plasma flame temperature (greater than $15,000^{\circ} \mathrm{K}$ ), thermal spray processes have a relatively high rate of materials' deposition in comparison to CVD and PVD coating processes. Thermal spray deposited coatings exhibit no mixing of substrate material to the substrate material, thus preserving base material composition.

The common major processing parameters in thermal spray methods are jet-velocity and temperature profiles, both derived from gas heating and flow parameters which determines whether enough energy or time is available to melt the powder particles. In combustion and plasma spray, a particle dwell time determines the degree of particle heating and is defined as the time a particles spends in the jet in a temperature zone, which is above the melting point of particle. Dwell time varies among the processes and even in a single jet as thermal spray jets have a distribution of gas velocities and temperatures. The second important parameter is the particles velocities which is dependent on the gas velocity distributions, with the resultant final particle velocity being determined by the jet/particle drag force. It is accepted that higher thermal spray jet velocities generally lead to higher "average" particle velocities. Particle velocities are important as it is accepted that higher particle velocity imparts higher impact energy, which leads to higher degree of splats deformation, better coating bonds and higher coating densities. On the other hand, higher particle velocities lead to shorter dwell times 
which results in less time for particle heating and may lead to lower coating densities, and a higher percentage of un-melted or partially melted phases present in the coating materials.

\section{Experimental Processing}

In this investigation, the following parameters were investigated and optimized to understand the splat formation, microstructure development and quenching stress in the thermal sprayed coatings:

1) Gun power and gas flow rate.

2) Powder feed rates for different types of powders.

3) Gun standoff distance and relative speed between the gun and the coating surface.

4) Substrate heating/cooling before, during, and after spraying

The iron, aluminum coated powders were sprayed using Plasma Spraying in presence of hydrogen argon atmosphere and High Velocity Oxygen Fuel (HVOF) processes. In this program plasma spray process was used for the spraying of alumina reinforced iron aluminide layers coating for producing the high temperature, corrosion, wear, carburization, sulfidization and oxidation resistant coating in one design. For this evaluation, a Sulzer-Metco 9MB type spray torch was used with an external powder injection system employing a No. 6 powder port set-up. The primary plasma gas was argon, with hydrogen used to control plasma voltage.

The major difficulty encountered in spraying the micro-engineered powders was achieving powder flow during spraying. Table 3 represents plasma sprayed coating composition and thickness during initial development run.

Table 3. Layer Thicknesses of iron Aluminide Coating

\begin{tabular}{|c|c|c|}
\hline Hardness (VHN) & Aim Thickness, mm & Actual Thickness, mm \\
\hline 420 & $6-8 \mathrm{mil}$ & 9 mil \\
\hline
\end{tabular}

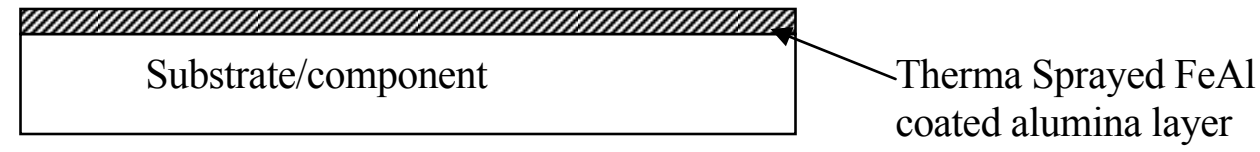

Figure 14: Technical Approach of Thermal Spray Coating on 718 and 304 Substrate 
Figure 14 represents the technical approach for thermal spray coating. Figure 15 to Figure 16 represent the scanning electron microscope (SEM) micrograph/ Energy Dispersive Spectroscopy (EDS) analysis of inconnel 718 substrate before thermal spray coating and EDS analysis reveals that the substrate is comprised of Ni, Fe, Cr, Ti and Al.

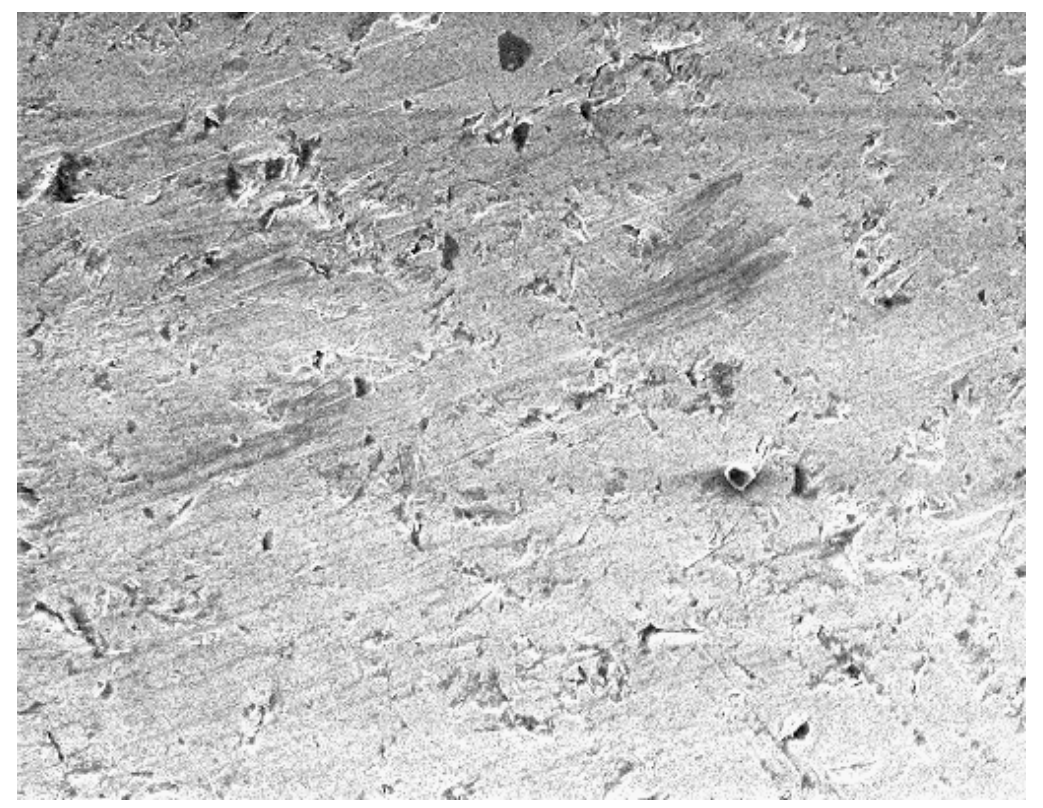

Figure 15: SEM Micrograph of Substrate Inconnel 718 X160

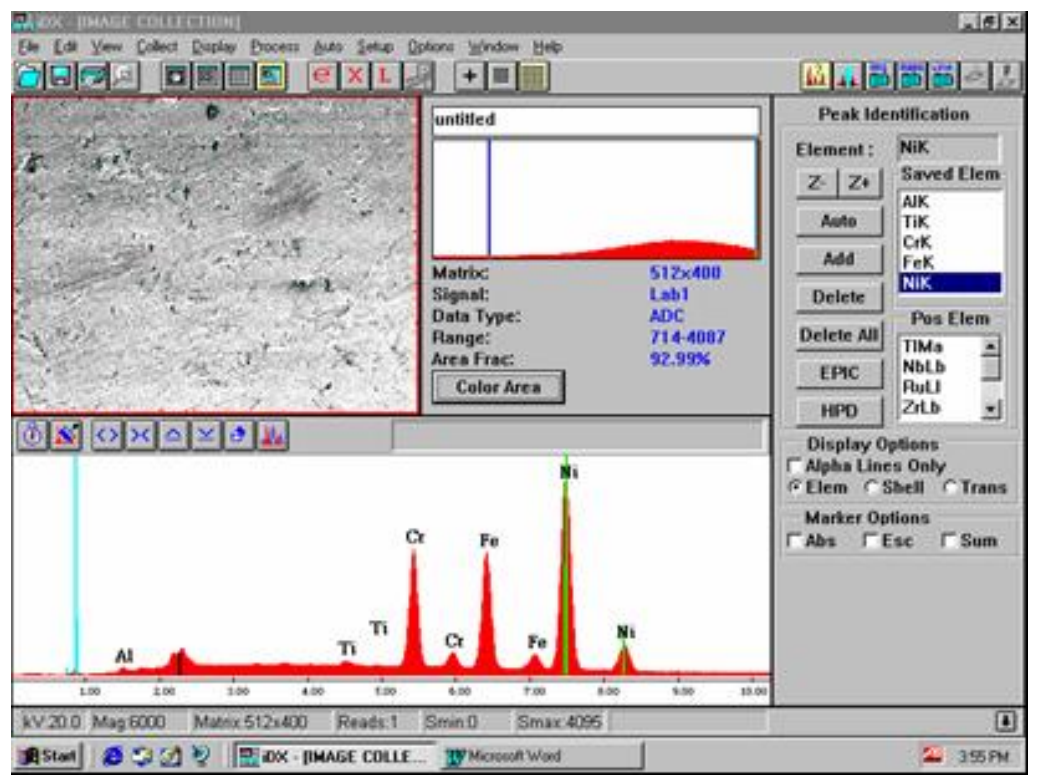

Figure 16: EDS analysis show Ni, Fe, $\mathrm{Cr}, \mathrm{Al}$ in inconel 718 
Figure 17 to Figure 18 represent the SEM micrograph, EDS analysis and X ray mapping of as sprayed (Plasma Spray) structure on inconnel 718. EDS analysis and X ray mapping confirmed that the inconnel substrate is nicely covered by iron aluminide sprayed structure as there was no nickel or chromium peaks found in the EDS analysis.

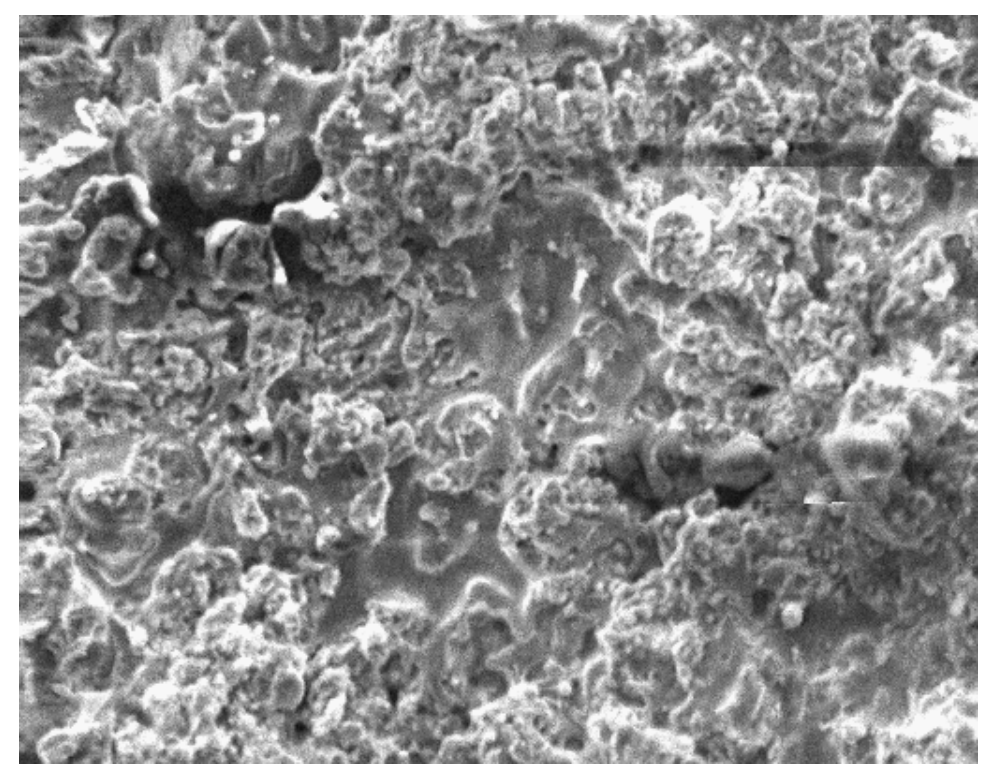

Figure 17 : SEM photomicrograph of as sprayed structure $\mathrm{X} 430$

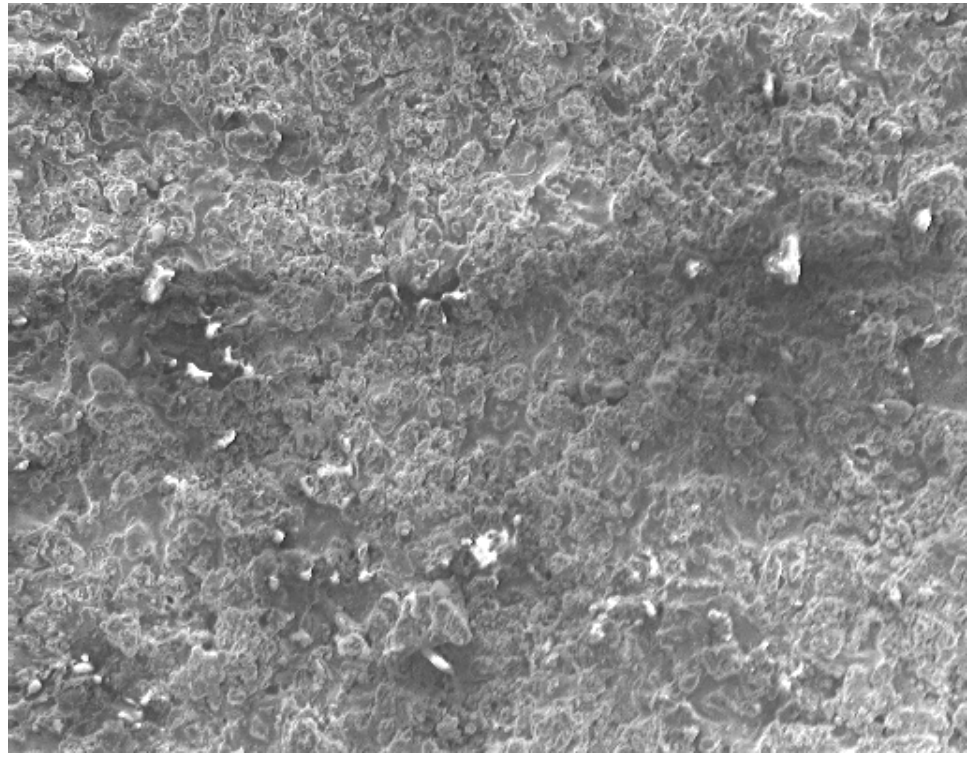

Figure 18: SEM micrograph of as sprayed structure X160 


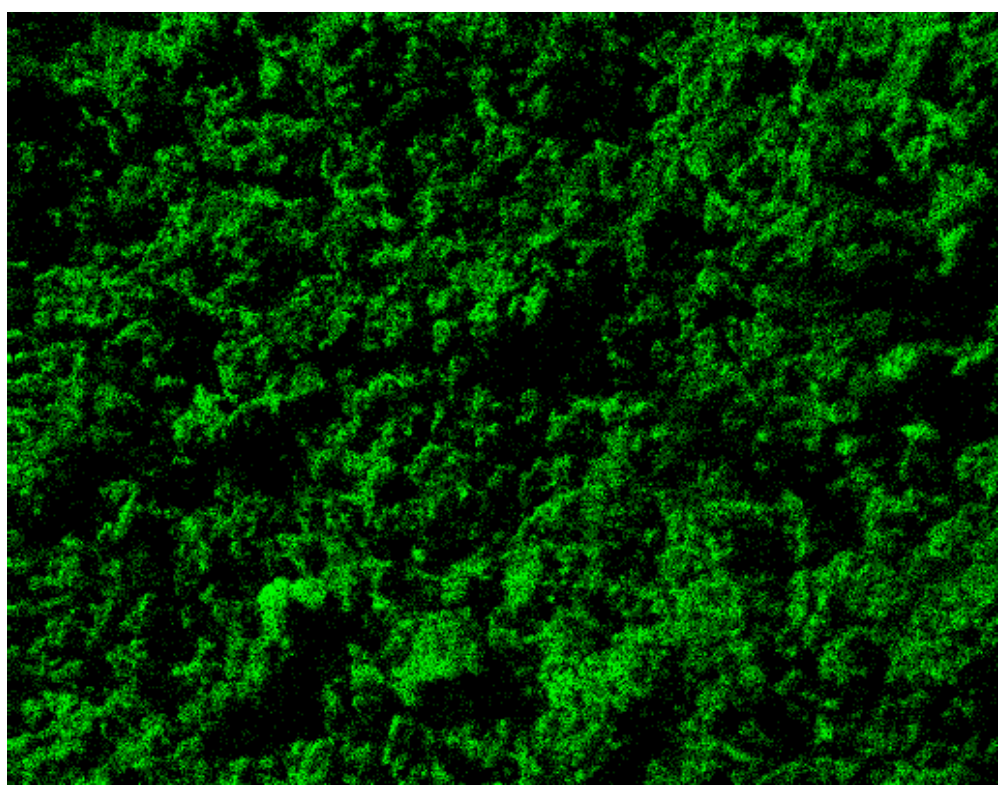

Figure 19: X ray mapping of Aluminum

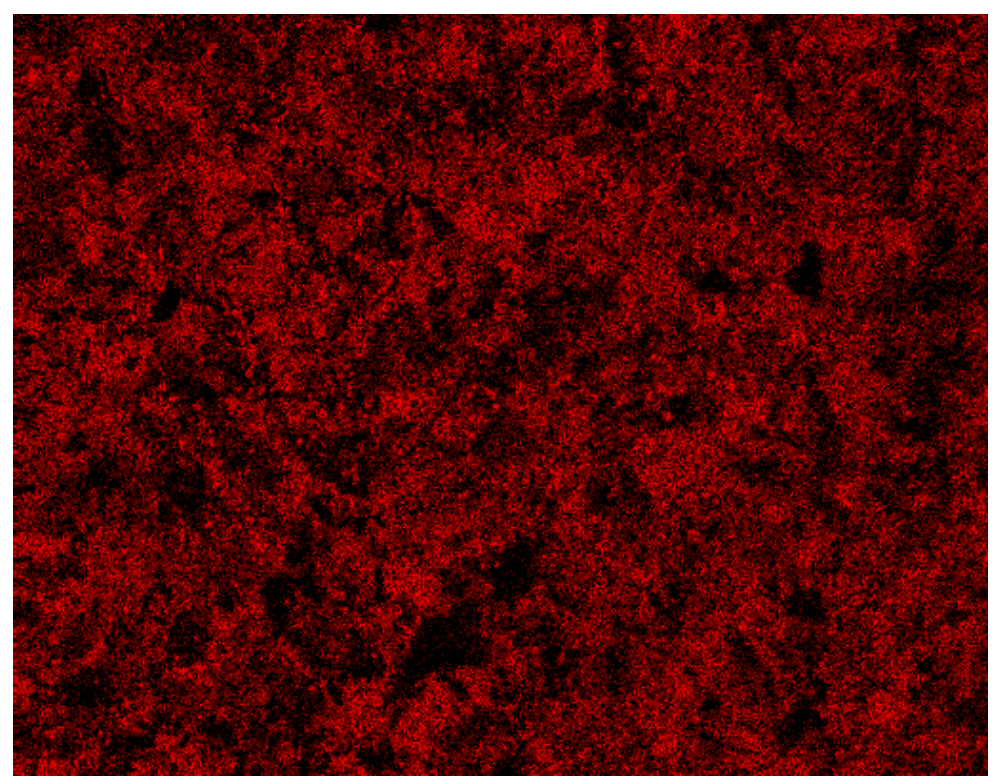

Figure 20: Xray mapping of Iron 


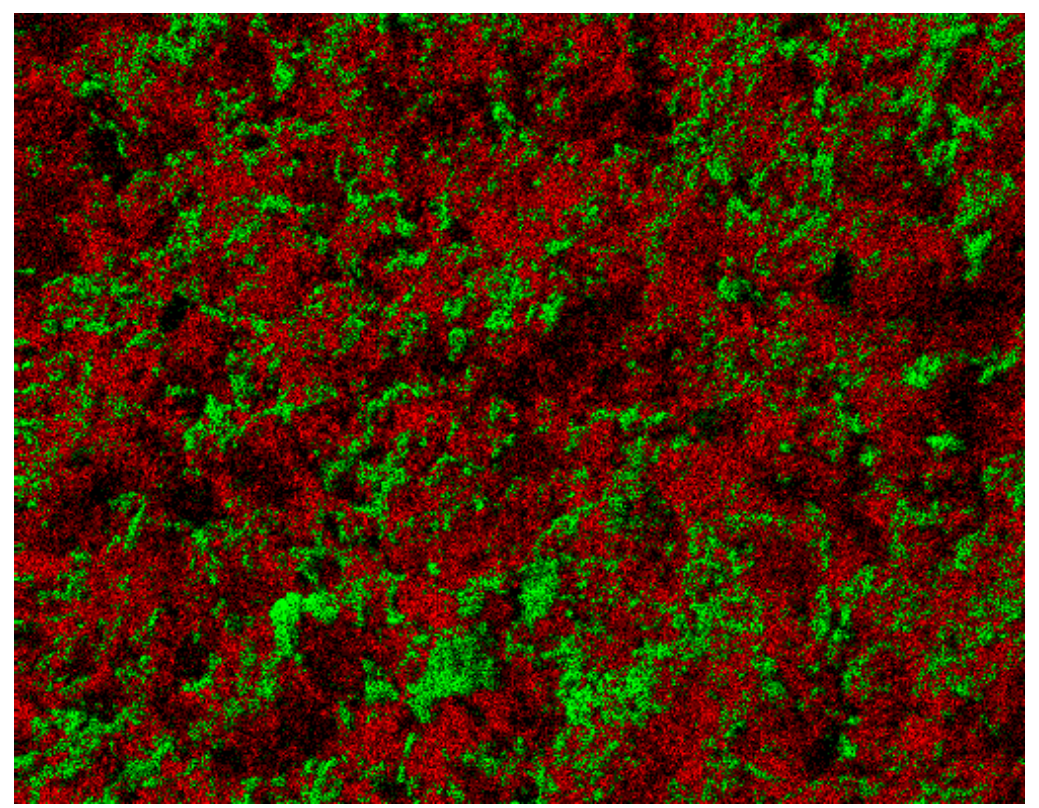

Figure 21: EDS analysis of Overlayed Iron-Aluminum

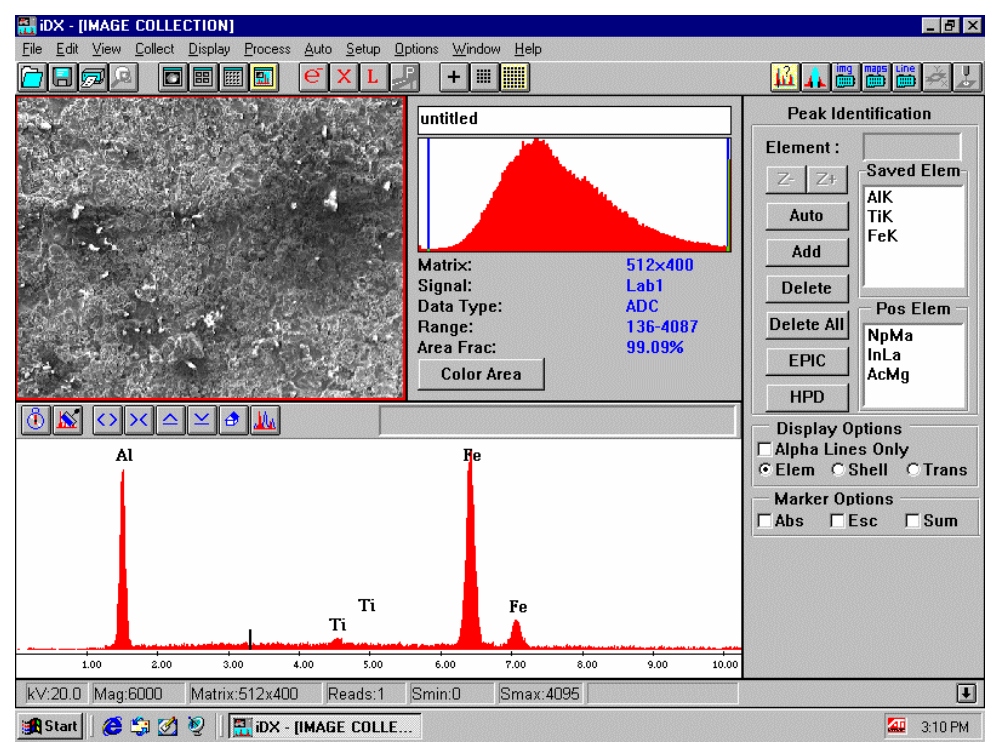

Figure 22: EDS analysis of as sprayed structure show no nickel and chromium from the substrate, which confirm the coverage

Figure 16 to Figure 26 represent the polished optical micrograph, SEM micrograph, EDS analysis and Xray mapping of sprayed (Plasma Spray) structure and inconnel 718 substrate. EDS analysis and $\mathrm{X}$ ray mapping confirmed that the inconnel substrate is nicely covered by iron aluminide sprayed structure with good interface bonding at the substrate and sprayed structure 


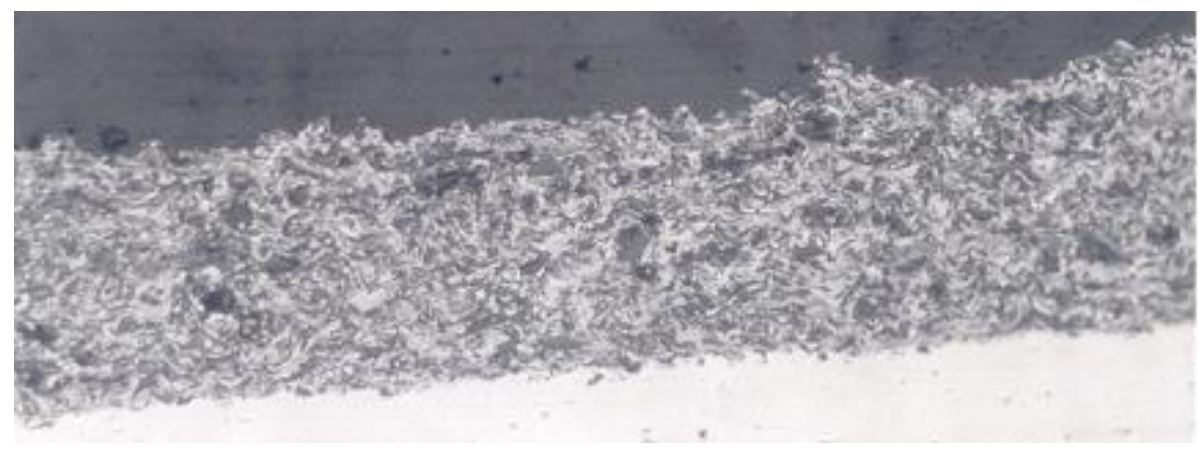

Figure 23: Polished/Optical micrograph of alumina reinforced iron aluminide plasma sprayed layer

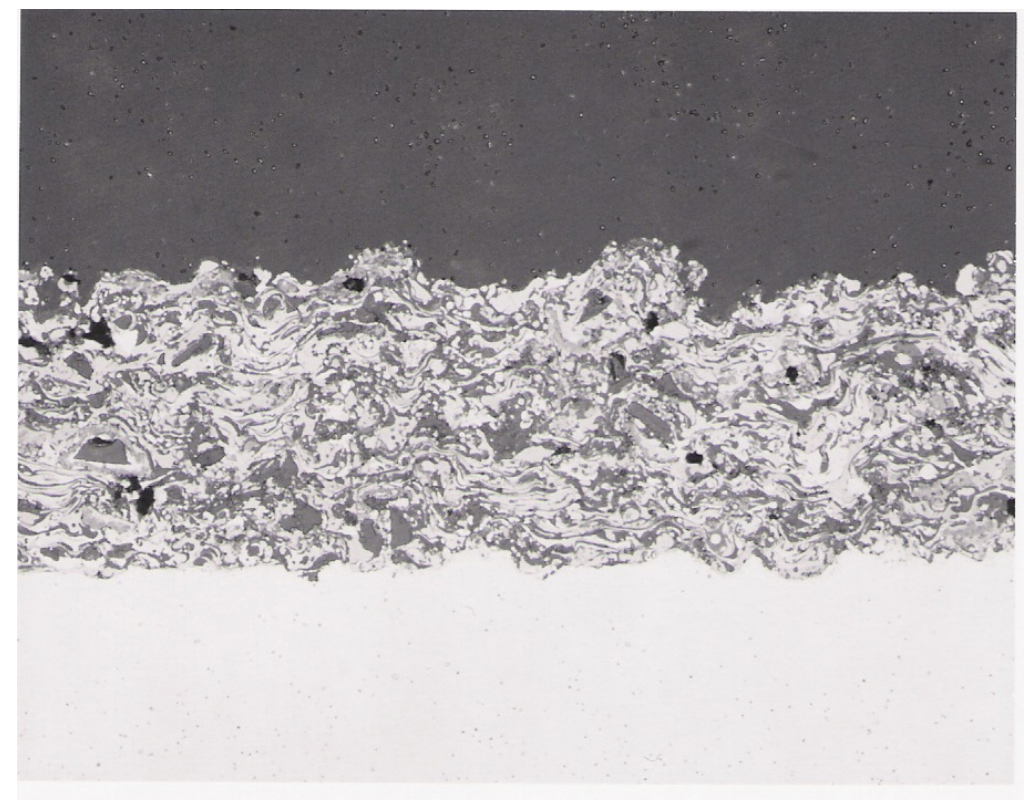

Figure 24: Polished/Optical micrograph of alumina reinforced iron aluminide plasma sprayed layer 


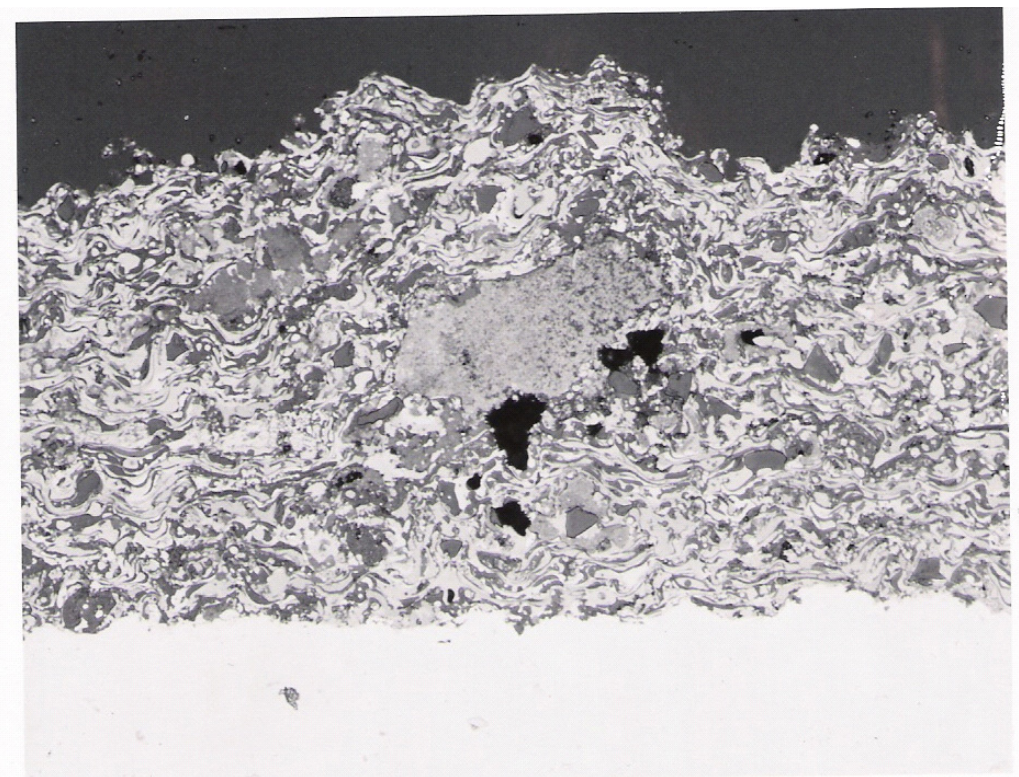

Figure 25: Polished/Optical micrograph of alumina reinforced iron aluminide plasma sprayed layer-show some agglomerates

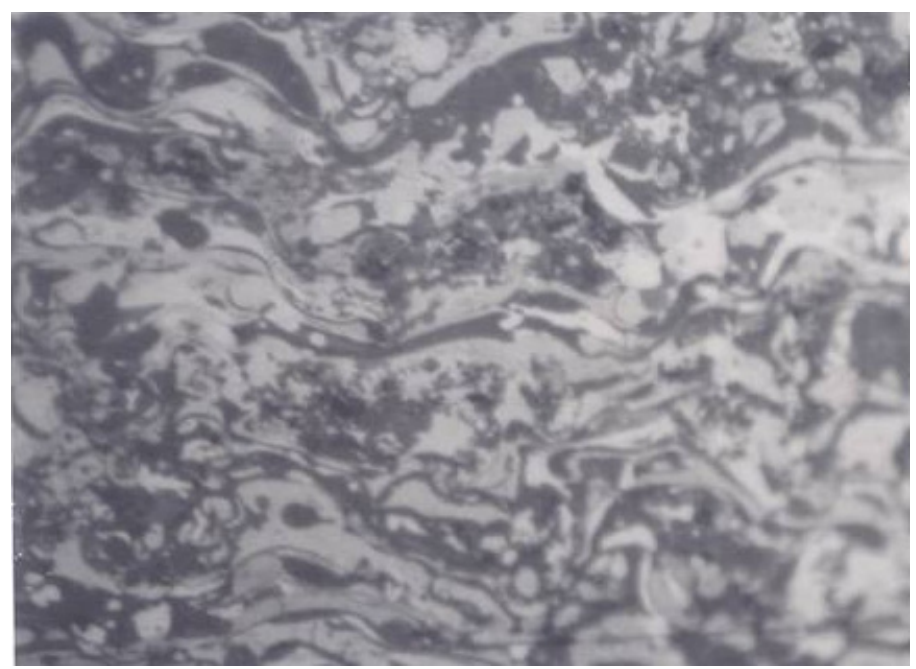

Figure 26: Polished/Optical micrograph of alumina reinforced iron aluminide plasma sprayed layer 


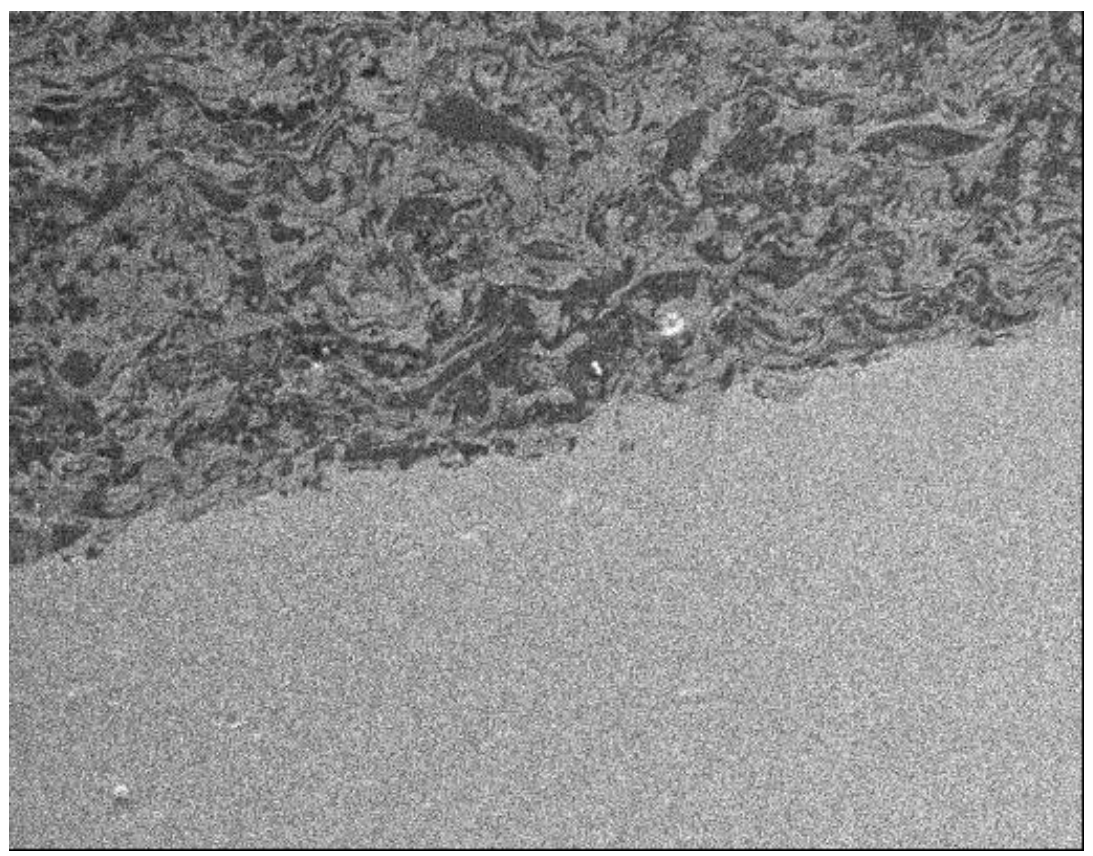

Figure 27:SEM micrograph of alumina reinforced iron aluminide plasma sprayed structure showing good interface bonding with substrate

Powdermet optimized and fine tuned spray parameters and finally plasma sprayed and HVOF sprayed coating on Inconel 718 and 304H stainless steel substrate using following spray parameters. Table 4 represents plasma sprayed coating composition and thickness.

Table 4 : Plasma Sprayed $\mathrm{Fe}_{3} \mathrm{Al}$ and Alumina reinforced $\mathrm{Fe}_{3} \mathrm{Al}$ Coating on 718 and 304 H substrate

\begin{tabular}{|c|c|c|}
\hline $\begin{array}{l}\text { Substrate } \\
\text { Composition }\end{array}$ & $\begin{array}{l}\text { Coating Layer } \\
\text { Composition }\end{array}$ & Coating Thickness (mil) \\
\hline 1 Inconel 718 & Alumina reinforced $\mathrm{Fe}_{3} \mathrm{Al}$ & $9-11$ \\
\hline 2 Inconel 718 & $\mathrm{Fe}_{3} \mathrm{Al}$ & $9-11$ \\
\hline 3 304H Stainless Steel & Alumina reinforced $\mathrm{Fe}_{3} \mathrm{Al}$ & $9-12$ \\
\hline $4 \quad 304 \mathrm{H}$ Stainless Steel & $\mathrm{Fe}_{3} \mathrm{Al}$ & $9-11$ \\
\hline
\end{tabular}

Figure 28 to figure 35 represent iron aluminide and alumina reinforced iron aluminide coating on $304 \mathrm{H}$ and IN 718 substrate by plasma spray and HVOF process. Figure show adherent and diffect free coating. 


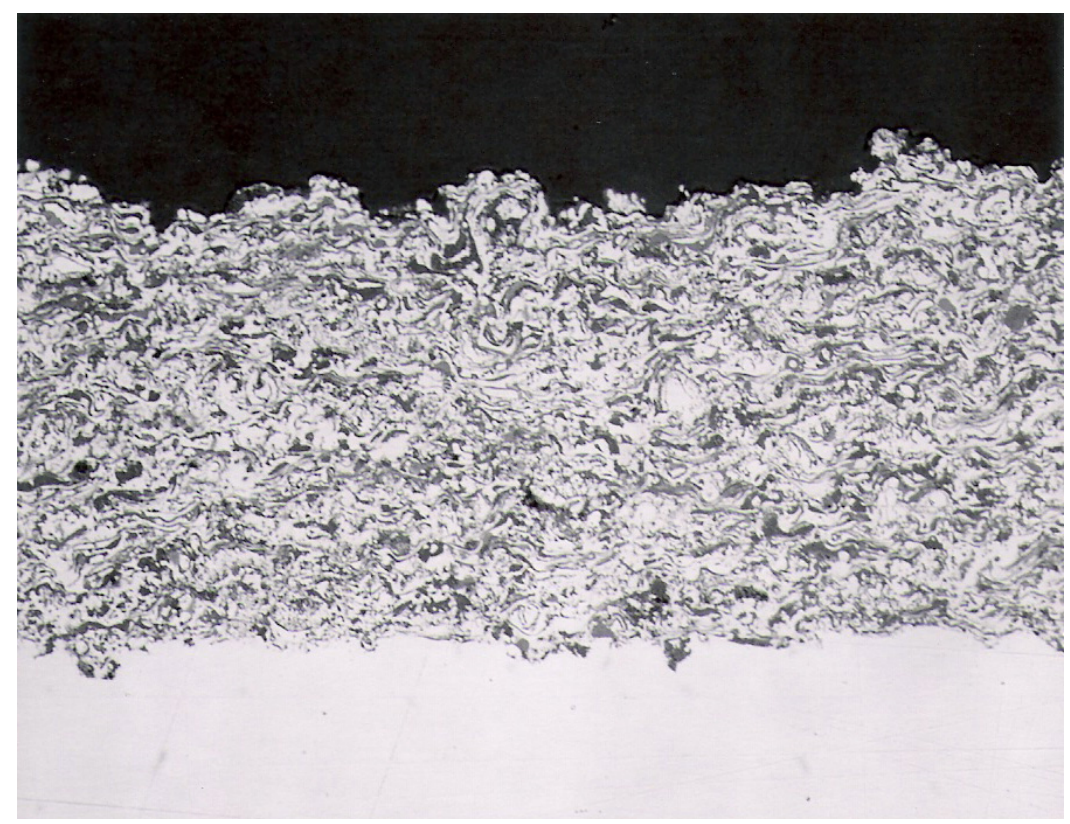

Figure 28: Plasma Sprayed $\mathrm{Fe}_{3} \mathrm{Al}$ on $304 \mathrm{H}$, coating thickness .009-.0105 inch X200

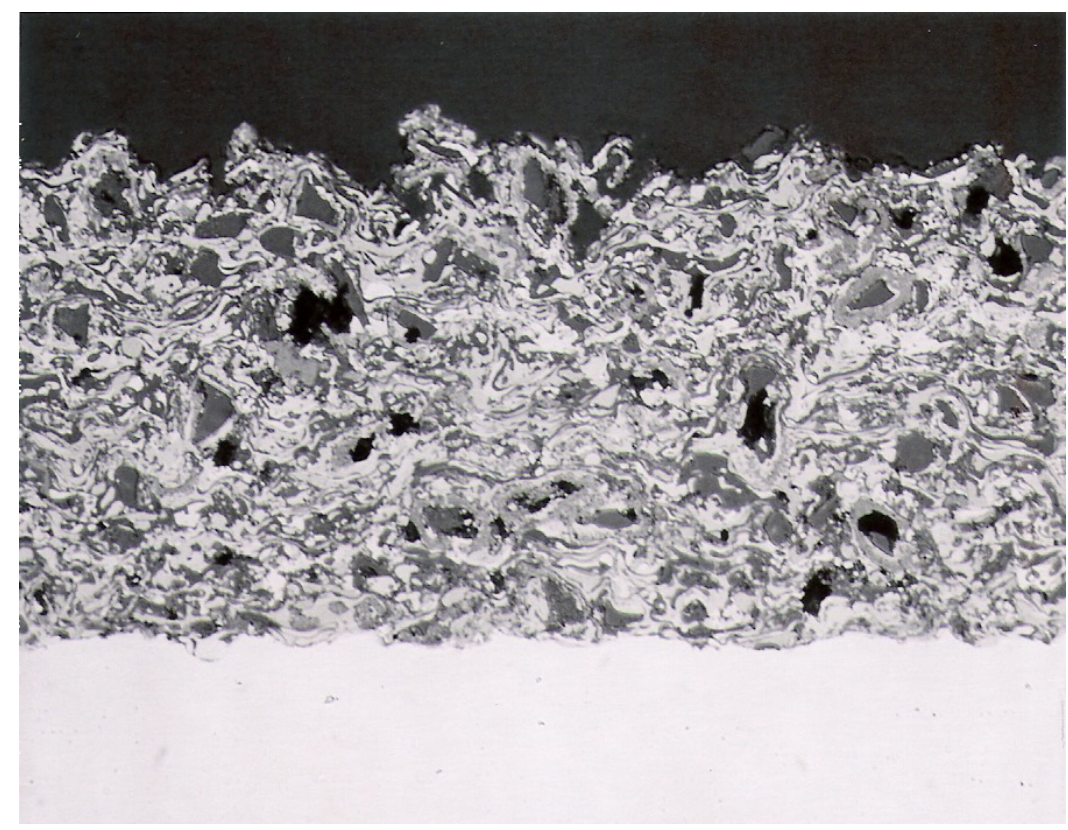

Figure 29: Plasma Sprayed Alumina reinforced $\mathrm{Fe}_{3} \mathrm{Al}$ on $304 \mathrm{H}$, coating thickness .009.012 inch X200 


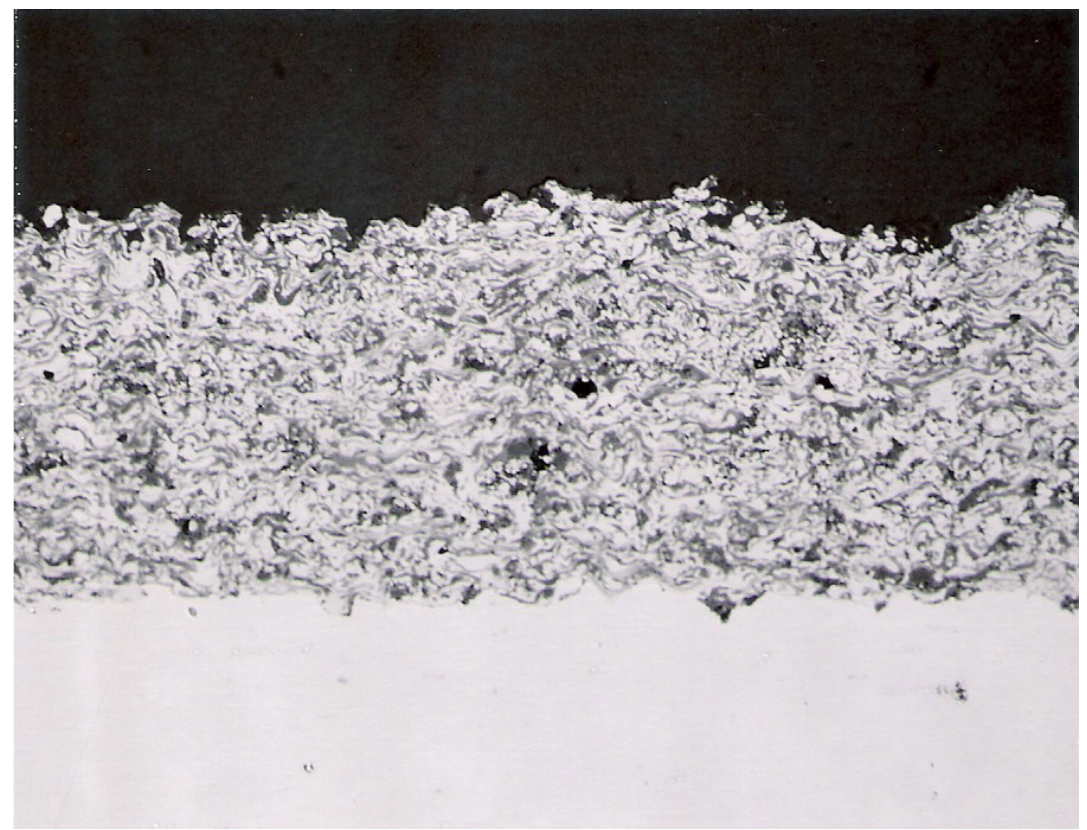

Figure 30: Plasma Sprayed $\mathrm{Fe}_{3} \mathrm{Al}$ on 718 coating thickness: .0075-.009 inch X200

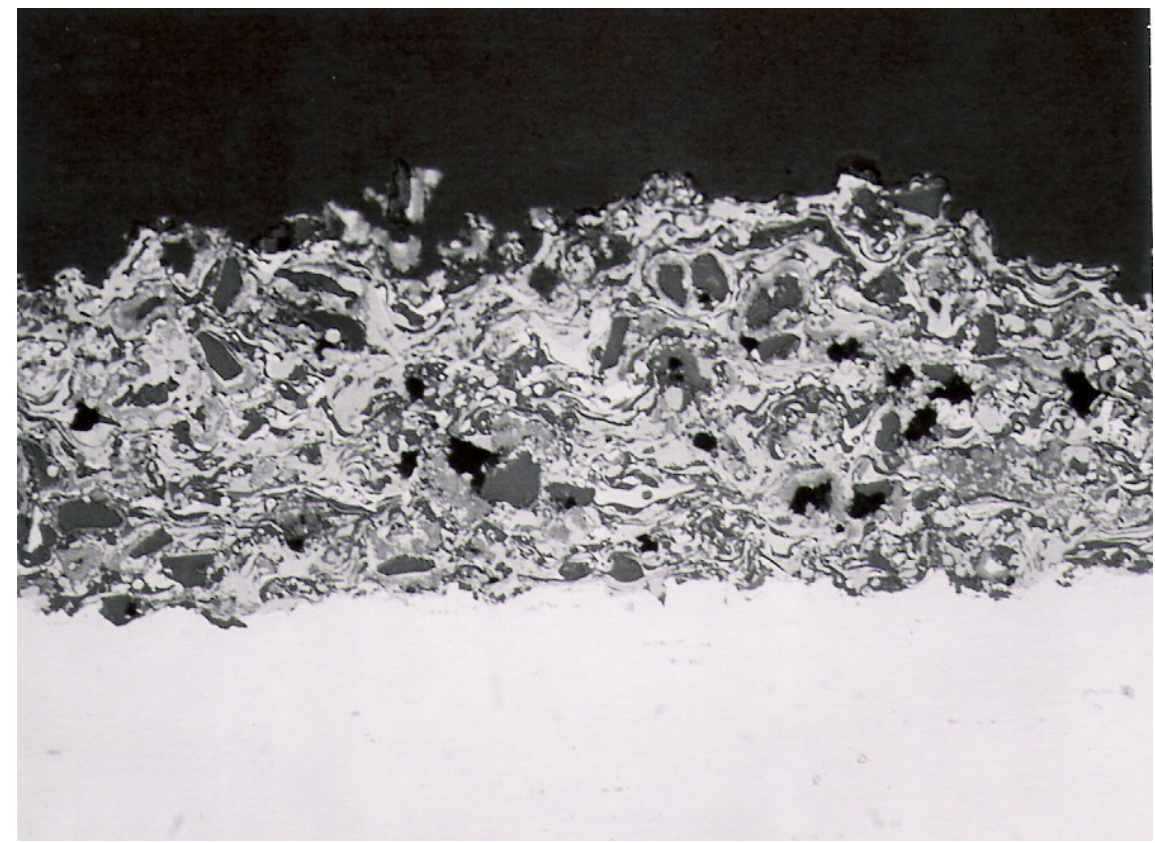

Figure 31: Plasma Sprayed Alumina reinforced $\mathrm{Fe}_{3} \mathrm{Al}$ on 718, coating thickness .006-.008 inch X200

Similarly Fe3Al and alumina reinforced Fe3Al coatings were sprayed on $304 \mathrm{H}$ and IN 718 substrate by HVOF. But Fe3Al could not be sprayed more than 2 mils incase of HVOF process incase of spraying 9-10 micron size aluminum iron coated iron powders. Probably spray drying is necessary. Table 5 represents HVOF sprayed coating composition and thickness 
Table 5: HVOF Sprayed $\mathrm{Fe}_{3} \mathrm{Al}$ and Alumina reinforced $\mathrm{Fe}_{3} \mathrm{Al}$ Coating on IN 718 and 304 H substrate

\begin{tabular}{|ll|l|c|}
\hline $\begin{array}{l}\text { Substrate } \\
\text { Composition }\end{array}$ & $\begin{array}{l}\text { Coating Layer } \\
\text { Composition }\end{array}$ & $\begin{array}{c}\text { Actual Coating Thickness } \\
\text { (mil) }\end{array}$ \\
\hline 1 & 718 & Alumina reinforced $\mathrm{Fe}_{3} \mathrm{Al}$ & $10-11$ \\
\hline 2 & 718 & $\mathrm{Fe}_{3} \mathrm{Al}$ & 2 \\
\hline 3 & $304 \mathrm{H}$ & Alumina reinforced $\mathrm{Fe}_{3} \mathrm{Al}$ & $10-11$ \\
\hline 4 & $304 \mathrm{H}$ & $\mathrm{Fe}_{3} \mathrm{Al}$ & 2 \\
\hline
\end{tabular}

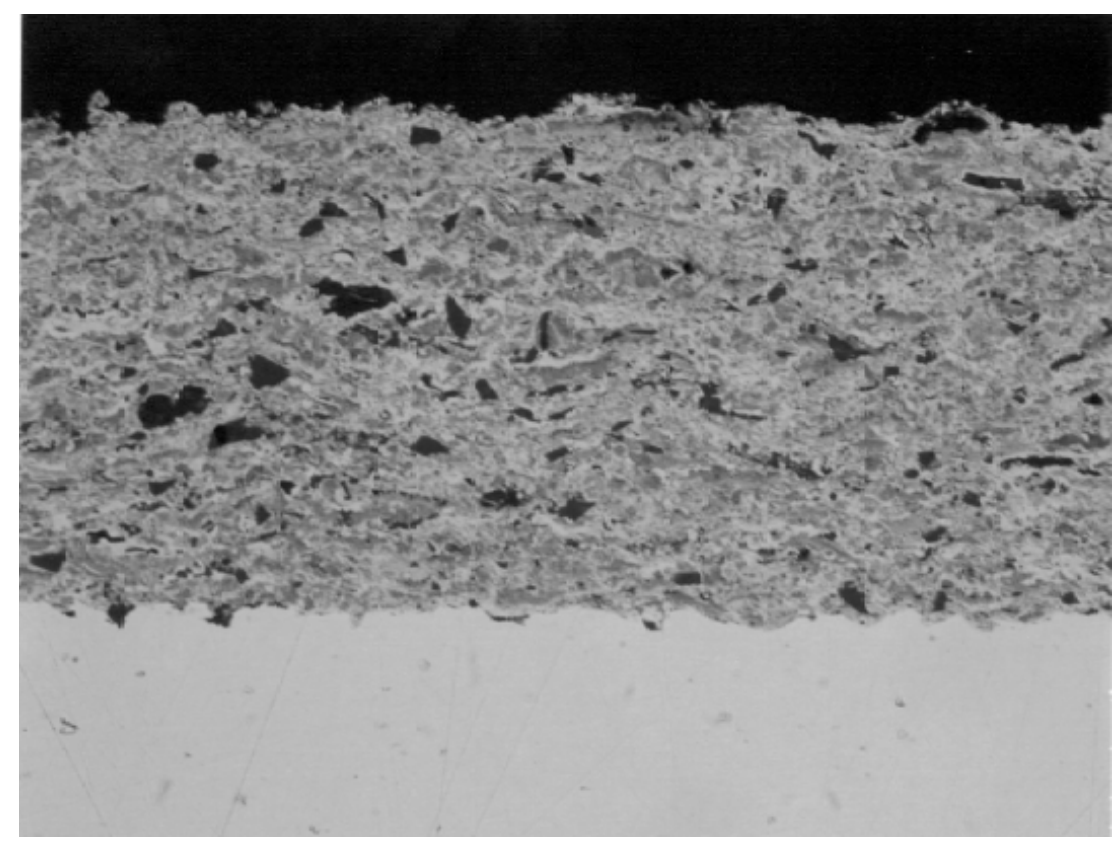

Figure 32: HVOF alumina reinforced $\mathrm{Fe}_{3} \mathrm{Al}$ on 718 - coating thickness .010/.011 inch X200 


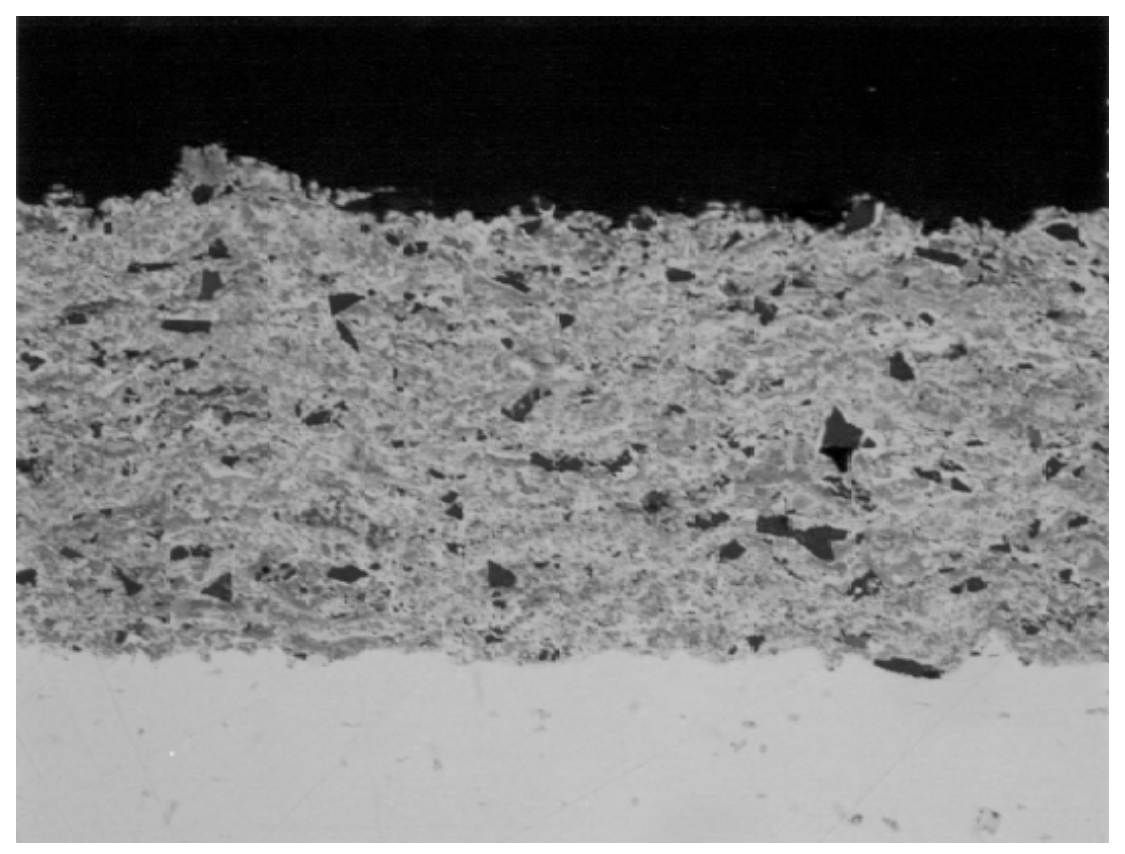

Figure 33: HVOF alumina reinforced $\mathrm{Fe}_{3} \mathrm{Al}$ on 304 X200 coating thickness .010/.011 inch

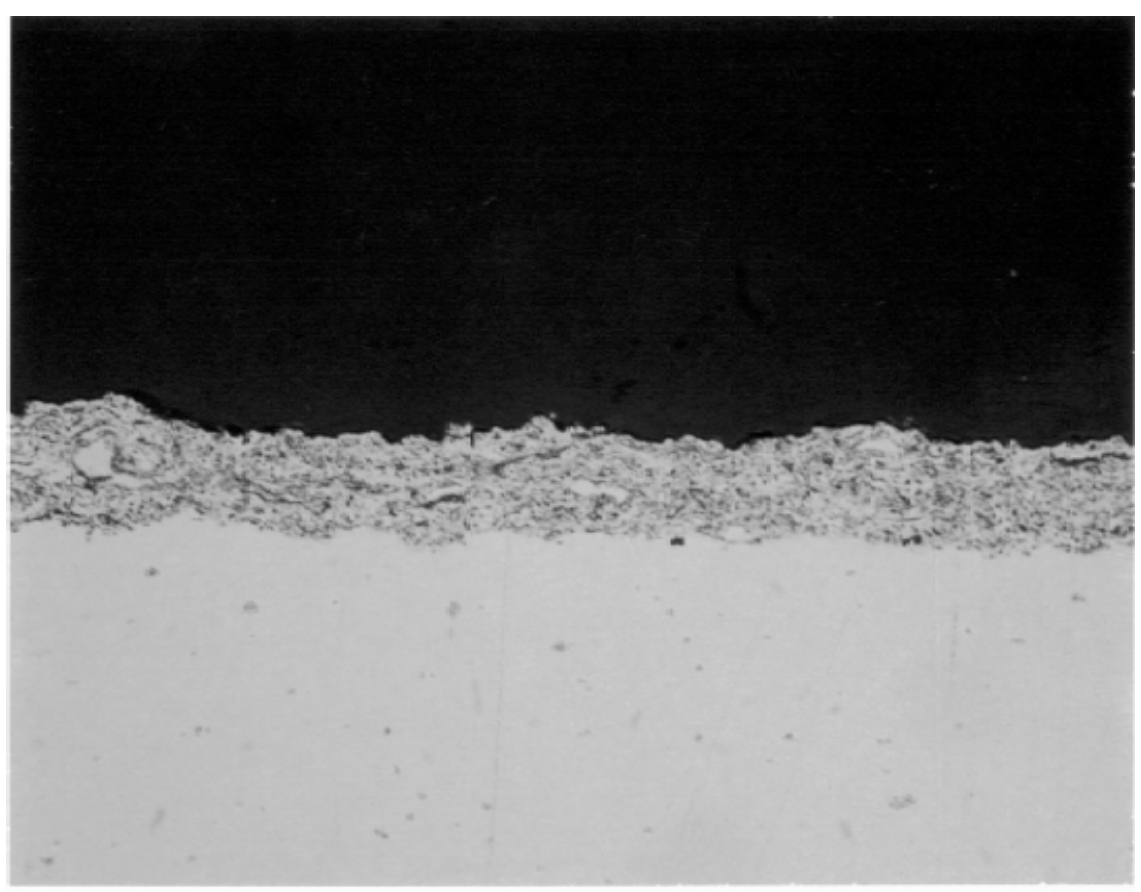

Figure 34: $\mathrm{HVOF} \mathrm{Fe}_{3} \mathrm{Al}$ on 304 -coating thickness .002 inch X200 


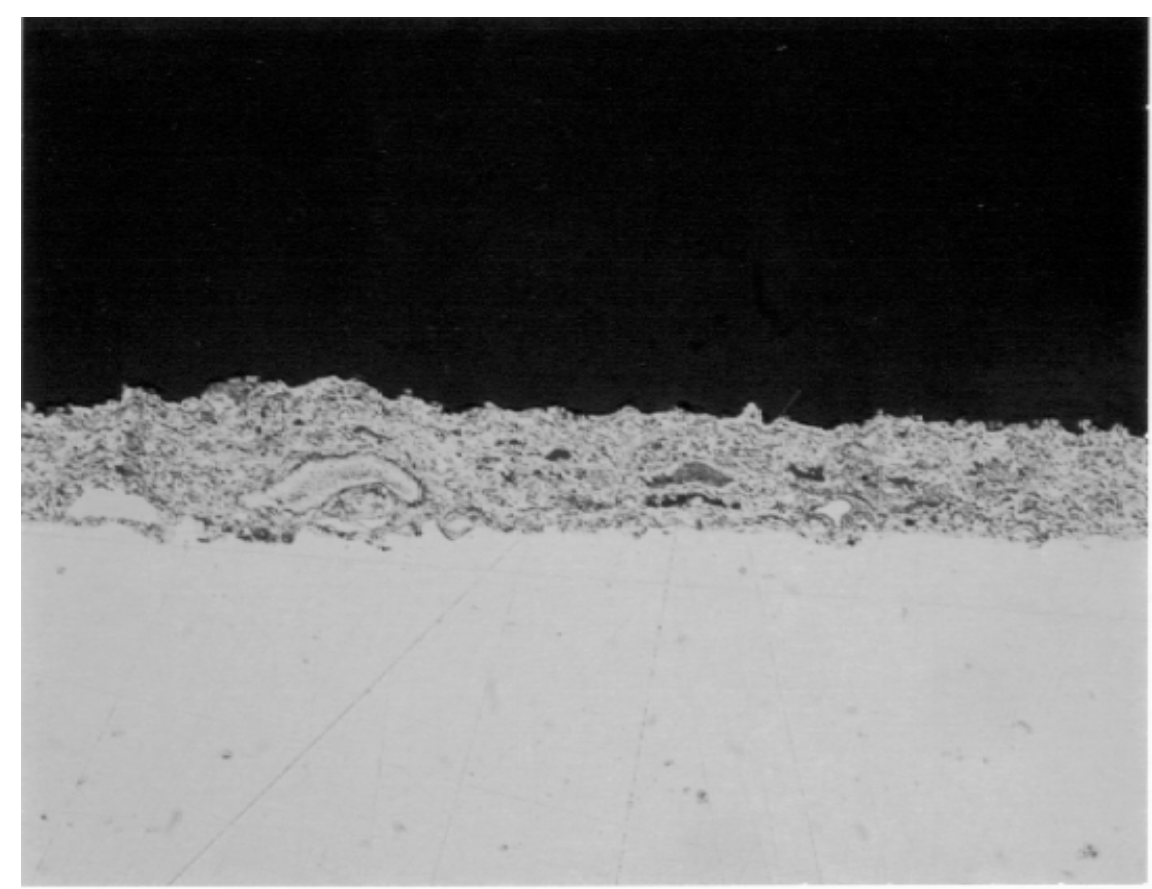

Figure 35: $\mathrm{HVOF} \mathrm{Fe}_{3} \mathrm{Al}$ on $718 \mathrm{X} 200$ coating thickness .002 inch

Hardness Test: Hardness was measured using a Vickers diamond pyramid indenter at 300 gram loads.

Plasma Sprayed Alumina reinforced $\mathrm{Fe}_{3} \mathrm{Al}$ coating on 718 - Average hardness 422.4 Vickers hardness number (VHN), Thickness $=.006 / .0085 \%$

Plasma Sprayed $\mathrm{Fe}_{3} \mathrm{Al}$ coating on 718 - average hardness was $425.8 \mathrm{VHN}$, thickness $=$ $.0065 / .009 "$

Plasma Sprayed Alumina reinforced $\mathrm{Fe}_{3} \mathrm{Al}$ coating on 304, average hardness was 372.4 VHN, thickness $=.009 / .012 "$

Plasma Sprayed $\mathrm{Fe}_{3} \mathrm{Al}$ coating on 304 Average hardness was 395.6, thickness $=.0091$ / $.0105 "$

Detailed hardness results are presented in table 6 to table 13. Hardness value of HVOF sprayed coating are higher than plasma sprayed coating 
Table 6: Hardness of Plasma sprayed Alumina Reinforced $\mathrm{Fe}_{3} \mathrm{Al}$ on 718

\begin{tabular}{|l|l|l|l|l|}
\hline Test \# & $\begin{array}{l}\text { Coating } \\
\text { Thickness }\end{array}$ & VHN & Load & $\begin{array}{l}\text { Average } \\
\text { Hardness (VHN) }\end{array}$ \\
\hline 1 & & 518.6 & & \\
\hline 2 & & 454.1 & & \\
\hline 3 & & 533.2 & & \\
\hline 4 & $.006 / .0085$ & 278.4 & $300 \mathrm{~g}$ & 422.4 \\
\hline 5 & & 459.3 & & \\
\hline 6 & & 411.9 & & \\
\hline 7 & & 331.7 & & \\
\hline 8 & & 472.8 & & \\
\hline 9 & & 343.3 & & \\
\hline 10 & & 421.0 & & \\
\hline
\end{tabular}

Table 7: Hardness of Plasma Sprayed $\mathrm{Fe}_{3} \mathrm{Al}$ on 718

\begin{tabular}{|l|l|l|l|l|}
\hline Test \# & $\begin{array}{l}\text { Coating } \\
\text { Thickness }\end{array}$ & VHN & Load & $\begin{array}{l}\text { Average } \\
\text { Hardness }\end{array}$ \\
\hline 1 & & 534.8 & & \\
\hline 2 & & 371.4 & & \\
\hline 3 & & 373.3 & & \\
\hline 4 & $.0065 / .009$ & 280.3 & $300 \mathrm{~g}$ & 425.8 \\
\hline 5 & & 616.0 & & \\
\hline 6 & & 229.3 & & \\
\hline 7 & & 405.2 & & \\
\hline 8 & & 489.8 & & \\
\hline 9 & & 529.9 & & \\
\hline 10 & & 428.0 & & \\
\hline
\end{tabular}

Table 8:Hardness of Plasma Sprayed Oxide reinforced Fe3Al coating on 304H

\begin{tabular}{|l|l|l|l|l|}
\hline Test \# & $\begin{array}{l}\text { Coating } \\
\text { Thickness }\end{array}$ & VHN & Load & $\begin{array}{l}\text { Average } \\
\text { Hardness }\end{array}$ \\
\hline 1 & & 458.0 & & \\
\hline 2 & & 385.2 & & \\
\hline 3 & & 345.9 & & \\
\hline 4 & $.0091 / .012$ & 290.6 & $300 \mathrm{~g}$ & 372.4 \\
\hline 5 & & 340.0 & & \\
\hline 6 & & 307.2 & & \\
\hline 7 & & 298.0 & & \\
\hline 8 & & 312.3 & & \\
\hline 9 & & 557.1 & & \\
\hline 10 & & 430.4 & & \\
\hline
\end{tabular}


Table 9: Hardness of Plasma Sprayed Fe3Al coating on 304H

\begin{tabular}{|l|l|l|l|l|}
\hline Test \# & $\begin{array}{l}\text { Coating } \\
\text { Thickness }\end{array}$ & VHN & Load & $\begin{array}{l}\text { Average } \\
\text { Hardness }\end{array}$ \\
\hline 1 & & 413.0 & & \\
\hline 2 & & 446.4 & & \\
\hline 3 & & 381.2 & & \\
\hline 4 & $.0091 / .0105$ & 330.1 & $300 \mathrm{~g}$ & 395.6 \\
\hline 5 & & 384.2 & & \\
\hline 6 & & 399.8 & & \\
\hline 7 & & 482.6 & & \\
\hline 8 & & 424.5 & & \\
\hline 9 & & 313.1 & & \\
\hline 10 & & 381.2 & & \\
\hline
\end{tabular}

\section{HVOF process:}

Table 10: Hardness of HVOF sprayed Alumina Reinforced Fe3Al on 718

\begin{tabular}{|l|l|l|l|l|}
\hline Test \# & $\begin{array}{l}\text { Coating } \\
\text { Thickness }\end{array}$ & VHN & Load & $\begin{array}{l}\text { Average } \\
\text { Hardness }\end{array}$ \\
\hline 1 & & 400.9 & & \\
\hline 2 & & 464.6 & & \\
\hline 3 & & 376.2 & & \\
\hline 4 & $.0101 / .011$ & 459.3 & $300 \mathrm{~g}$ & 490.03 \\
\hline 5 & & 518.6 & & \\
\hline 6 & & 529.9 & & \\
\hline 7 & & 564.2 & & \\
\hline 8 & & 562.4 & & \\
\hline 9 & & 434.0 & & \\
\hline 10 & & 590.2 & & \\
\hline
\end{tabular}

Table 11: Hardness of HVOF Sprayed Fe3Al on 718

\begin{tabular}{|l|l|l|l|l|}
\hline Test \# & $\begin{array}{l}\text { Coating } \\
\text { Thickness }\end{array}$ & VHN & Load & $\begin{array}{l}\text { Average } \\
\text { Hardness }\end{array}$ \\
\hline 1 & & 506.2 & & \\
\hline 2 & & 582.6 & & \\
\hline 3 & & 421.0 & & \\
\hline 4 & .002 & 482.6 & $300 \mathrm{~g}$ & 522.2 \\
\hline 5 & & 518.6 & & \\
\hline 6 & & 492.7 & & \\
\hline 7 & & 538.2 & & \\
\hline 8 & & 566.0 & & \\
\hline 9 & & 531.5 & & \\
\hline 10 & & 582.6 & & \\
\hline
\end{tabular}


Table 12: Hardness of HVOF Sprayed Oxide reinforced Fe3Al coating on 304H

\begin{tabular}{|l|l|l|l|l|}
\hline Test \# & $\begin{array}{l}\text { Coating } \\
\text { Thickness }\end{array}$ & VHN & Load & $\begin{array}{l}\text { Average } \\
\text { Hardness }\end{array}$ \\
\hline 1 & & 518.6 & & \\
\hline 2 & & 531.5 & & \\
\hline 3 & & 575.1 & & \\
\hline 4 & $.0101 / .011$ & 518.6 & $300 \mathrm{~g}$ & 518.43 \\
\hline 5 & & 550.1 & & \\
\hline 6 & & 452.8 & & \\
\hline 7 & & 510.8 & & \\
\hline 8 & & 513.9 & & \\
\hline 9 & & 492.7 & & \\
\hline 10 & & 520.2 & & \\
\hline
\end{tabular}

Table 13: Hardness of HVOF Sprayed $\mathrm{Fe}_{3} \mathrm{Al}$ coating on 304H

\begin{tabular}{|l|l|l|l|l|}
\hline Test \# & $\begin{array}{l}\text { Coating } \\
\text { Thickness }\end{array}$ & VHN & Load & \\
\hline 1 & & 495.7 & & \\
\hline 2 & & 489.8 & & \\
\hline 3 & & 513.9 & & \\
\hline 4 & .002 & 488.4 & $300 \mathrm{~g}$ & 504.01 \\
\hline 5 & & 531.5 & & \\
\hline 6 & & 601.9 & & \\
\hline 7 & & 488.4 & & \\
\hline 8 & & 491.3 & & \\
\hline 9 & & 426.8 & & \\
\hline 10 & & 512.4 & & \\
\hline
\end{tabular}

Erosion Test: Grid blast erosion test was done by alumina grit

Parameters used for the test are described below:

Erodent: SS White Alumina Powder

Erodent Size: $50-60$ microns

Erodent Mass Load: $600 \mathrm{gm}$

Air Pressure: 24.5 psi

Vibrator Pressure: 17 psi

Distance from nozzle: 4 inches

$\mathrm{Fe}_{3} \mathrm{Al}$ density: $6.5 \mathrm{~g} / \mathrm{cm}^{3}$

$\mathrm{Al}_{2} \mathrm{O}_{3}$ reinforced $\mathrm{Fe} 3 \mathrm{Al}$ density: $5.5 \mathrm{~g} / \mathrm{cm}^{3}$

Test Time: 103-106 seconds 
Table 14 represents Erosion Test Results of Plasma Spray and HVOF sprayed Fe3Al and Alumina Reinforced Fe3Al on IN 718 and 304H Substrate

Table 14: Erosion Test Results of Plasma Spray and HVOF sprayed Fe3Al and Alumina Reinforced Fe3Al on IN 718 and 304H Substrate

Erosion data for plasma sprayed samples

\begin{tabular}{|c|c|c|c|c|c|c|c|c|}
\hline Angle & Coating & $\begin{array}{c}\text { Time } \\
(\mathrm{sec})\end{array}$ & $\begin{array}{c}\mathbf{R i} \\
(\mu \mathrm{in})\end{array}$ & $\begin{array}{c}\mathbf{R f} \\
(\mu \mathrm{in})\end{array}$ & $\begin{array}{c}\mathbf{W i} \\
(\mathrm{gm})\end{array}$ & $\begin{array}{c}\mathbf{W f} \\
(\mathrm{gm})\end{array}$ & $\begin{array}{c}\text { Wi-Wf } \\
(\mathrm{gm})\end{array}$ & $\begin{array}{c}\text { Erosion } \\
\text { rate } \\
\mathrm{mg} / \mathrm{g}\end{array}$ \\
\hline \multirow{3}{*}{$90^{\circ}$} & $\begin{array}{c}\mathrm{Al}_{2} \mathrm{O}_{3}-\mathrm{Fe}_{3} \mathrm{Al} / \mathrm{Inco} \\
718\end{array}$ & 107.9 & 284 & 25 & 18.1826 & 17.998 & 0.1846 & 0.3076667 \\
\cline { 2 - 8 } & $\mathrm{Fe}_{3} \mathrm{Al} / \mathrm{Inco} 718$ & 104.8 & 184 & 67 & 17.8937 & 17.7608 & 0.1329 & 0.2215 \\
\cline { 2 - 9 } & $\mathrm{Al}_{2} \mathrm{O}_{3}-\mathrm{Fe} \mathrm{Al}_{3} \mathrm{Al} / 304 \mathrm{H}$ & 104.6 & 248 & 27 & 15.3563 & 15.1434 & 0.2129 & 0.3548333 \\
\cline { 2 - 8 } & $\mathrm{Fe}_{3} \mathrm{Al} / 304 \mathrm{H}$ & 111.8 & 183 & 71 & 15.2154 & 15.0776 & 0.1378 & 0.2296667 \\
\hline
\end{tabular}

Erosion data for HVOF coated samples

\begin{tabular}{|c|c|c|c|c|c|c|c|c|}
\hline Angle & Coating & $\begin{array}{c}\text { Time } \\
(\mathrm{sec})\end{array}$ & $\begin{array}{c}\mathbf{R i} \\
(\mu \mathrm{in})\end{array}$ & $\begin{array}{c}\mathbf{R f} \\
(\mu \mathrm{in})\end{array}$ & $\begin{array}{c}\mathbf{W i} \\
(\mathrm{gm})\end{array}$ & $\begin{array}{c}\text { Wf } \\
(\mathrm{gm})\end{array}$ & $\begin{array}{c}\text { Wi-Wf } \\
(\mathrm{gm})\end{array}$ & $\begin{array}{c}\text { Erosion } \\
\text { rate } \\
\mathrm{mg} / \mathrm{g}\end{array}$ \\
\hline \multirow{6}{*}{$90^{\circ}$} & $\begin{array}{c}\mathrm{Al}_{2} \mathrm{O}_{3}-\mathrm{Fe}_{3} \mathrm{Al} / \mathrm{Inco} \\
718\end{array}$ & 109.7 & 159 & $\begin{array}{c}32, \\
58\end{array}$ & 27.2279 & 27.0915 & 0.1364 & 0.2273333 \\
\cline { 2 - 9 } & $\mathrm{Fe}_{3} \mathrm{Al} / \mathrm{Inco} 718$ & 107.5 & 113 & 25 & 25.8163 & 25.7264 & 0.0899 & 0.1498333 \\
\cline { 2 - 9 } & $\mathrm{Al}_{2} \mathrm{O}_{3}-\mathrm{Fe}_{3} \mathrm{Al} / 304 \mathrm{H}$ & 109.9 & 164 & $\begin{array}{c}36, \\
49\end{array}$ & 27.3911 & 27.2541 & 0.137 & 0.2283333 \\
\cline { 2 - 9 } & $\mathrm{Fe}_{3} \mathrm{Al} / 304 \mathrm{H}$ & 105.1 & 124 & 25 & 25.6919 & 25.5997 & 0.0922 & 0.1536667 \\
\hline
\end{tabular}

$\mathrm{Ri}=$ Initial Roughness before Erosion test

$\mathrm{Rf}=$ Roughness after Erosion test

Thermal sprayed coating surface became smoother after erosion test. But coating remained intact after the test. Figure 36 to figure 41 represent the SEM photo micrograph and EDS analysis after Erosion test 


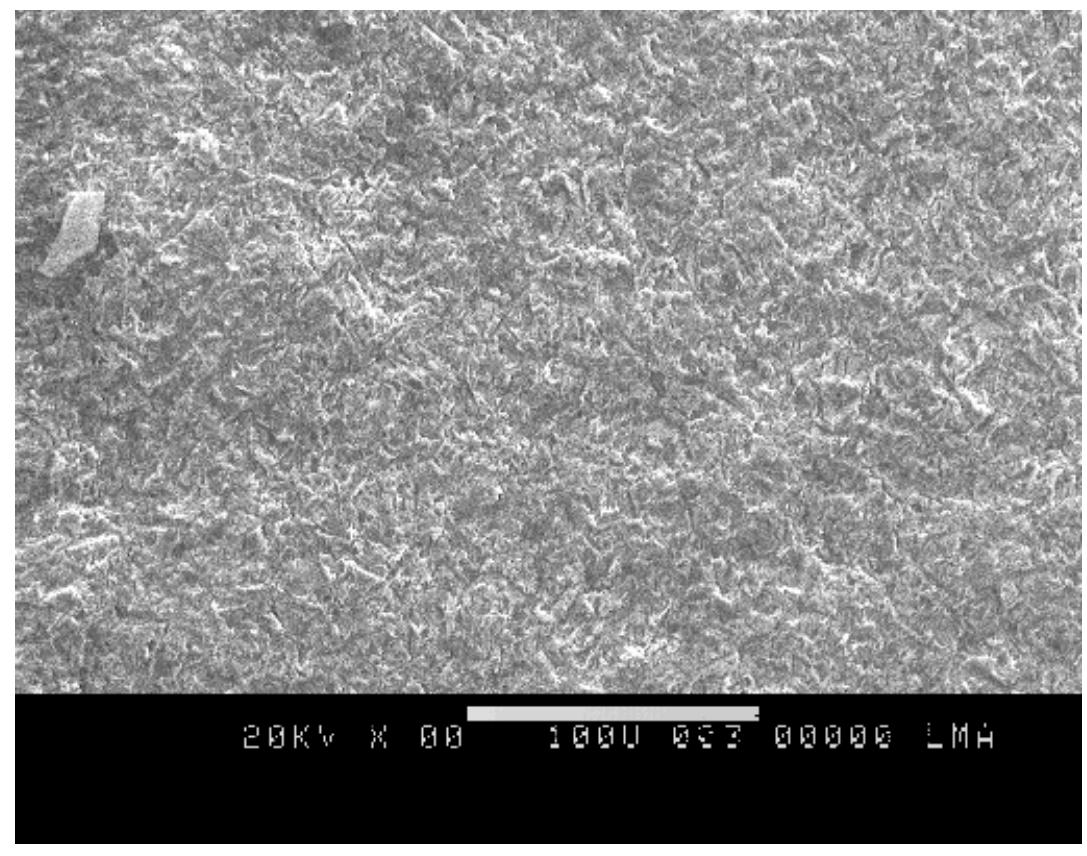

Figure 36: $\mathrm{Fe}_{3} \mathrm{Al}$ Coating on $304 \mathrm{H}$ substrate after erosion test. Coating remained intact and surface roughness reduced after erosion testX370

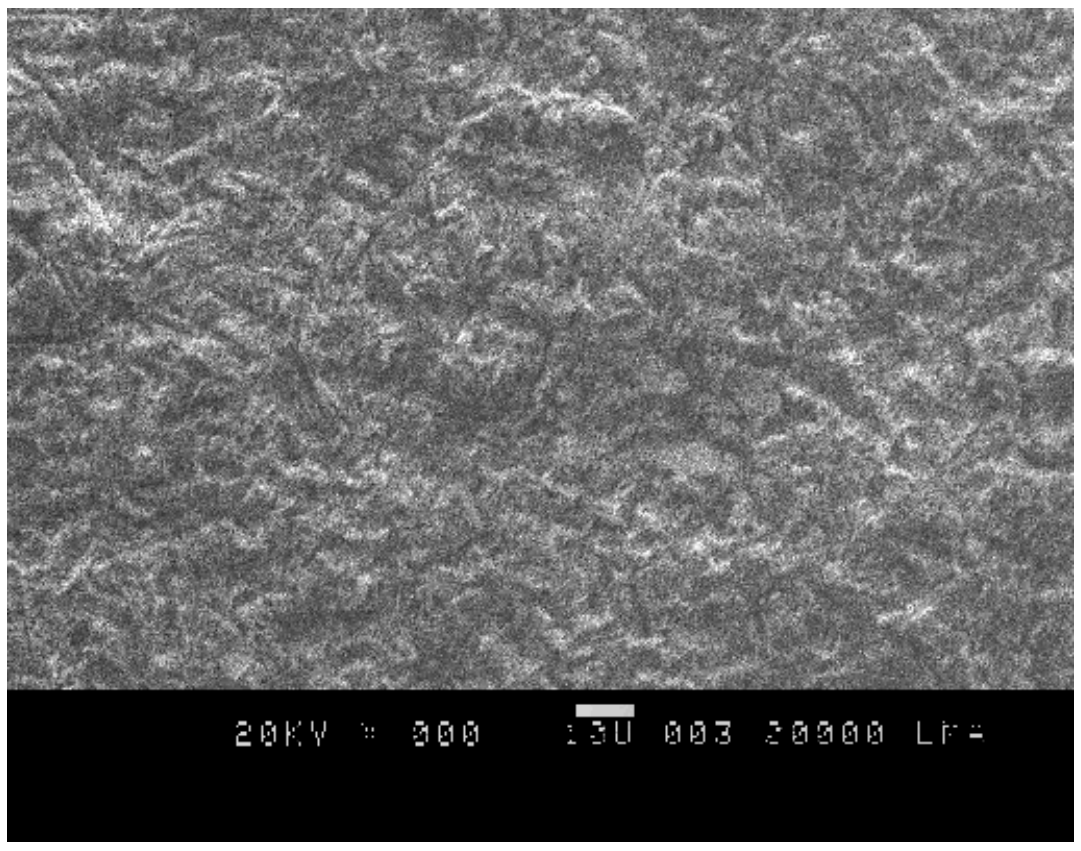

Figure 37: $\mathrm{Fe}_{3} \mathrm{Al}$ sprayed coating after Erosion Test $\mathrm{X} 700$ 


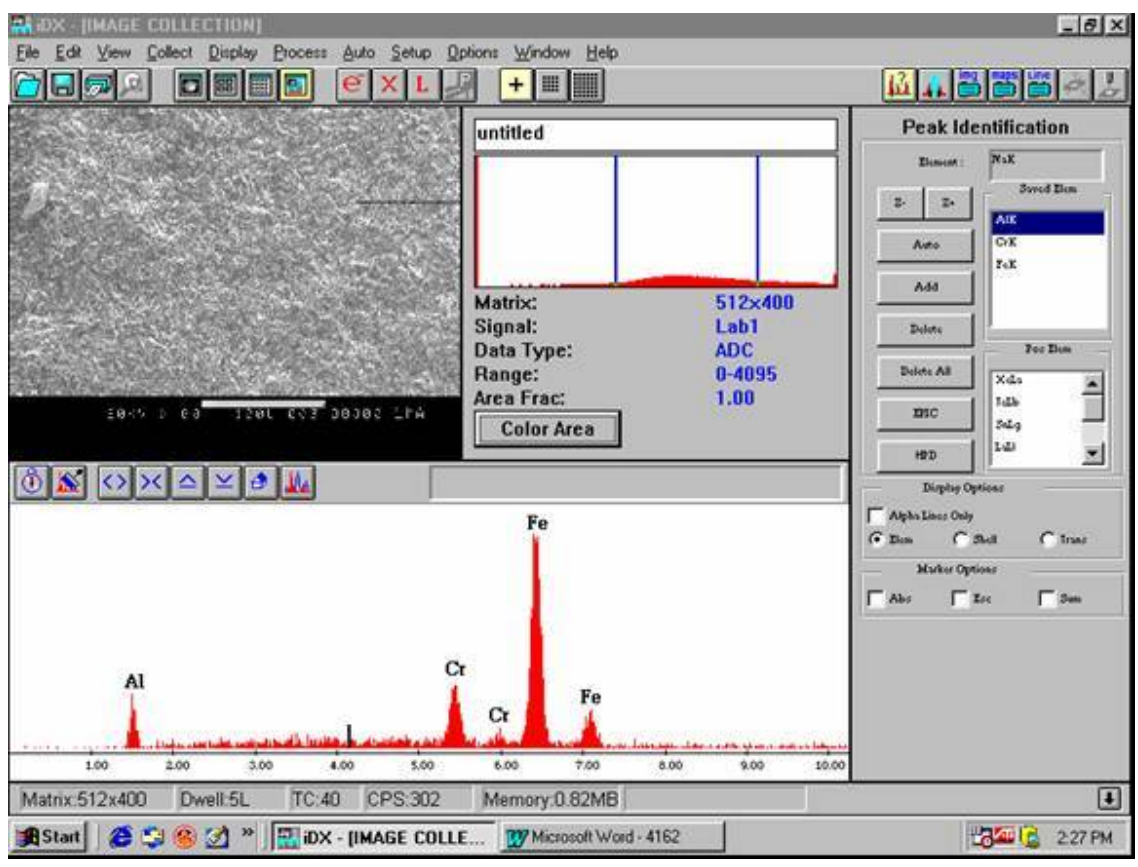

Figure 38: EDS analysis show alumina reinforced iron aluminide coating

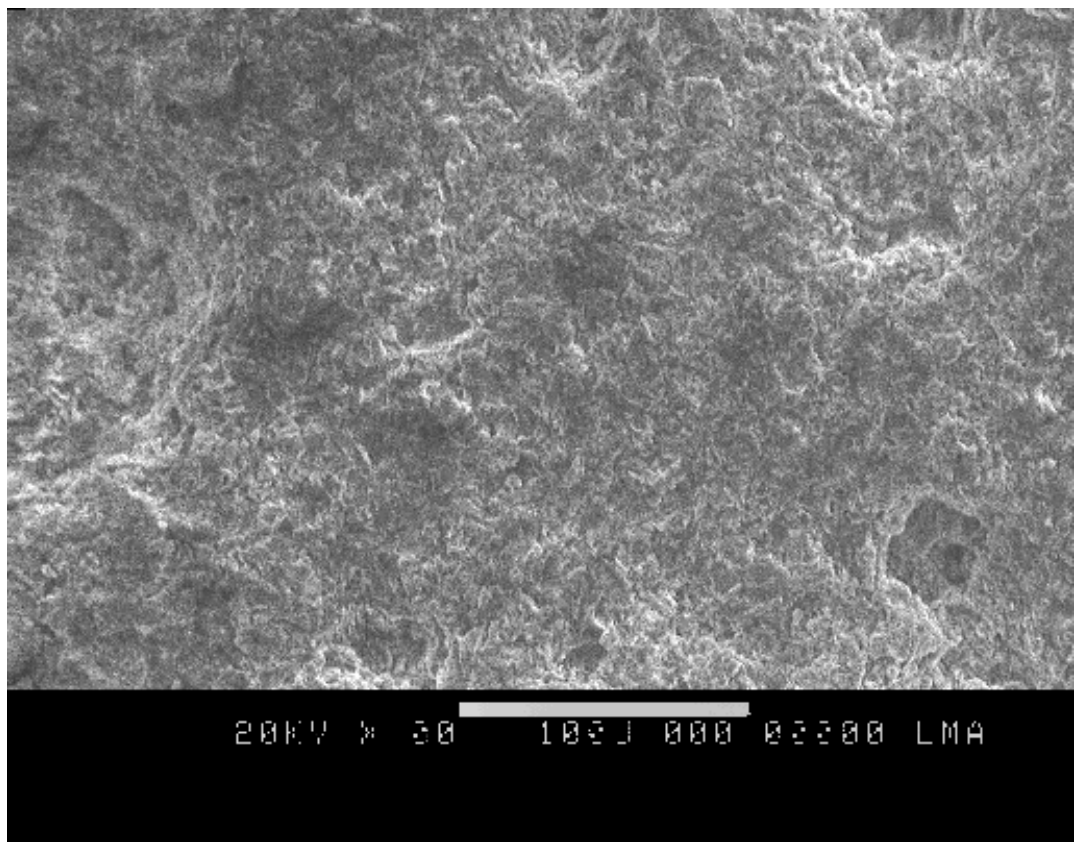

Figure 39: SEM micrograph showing alumina reinforced $\mathrm{Fe}_{3} \mathrm{Al}$ coating after erosion test showing eroded more X370 


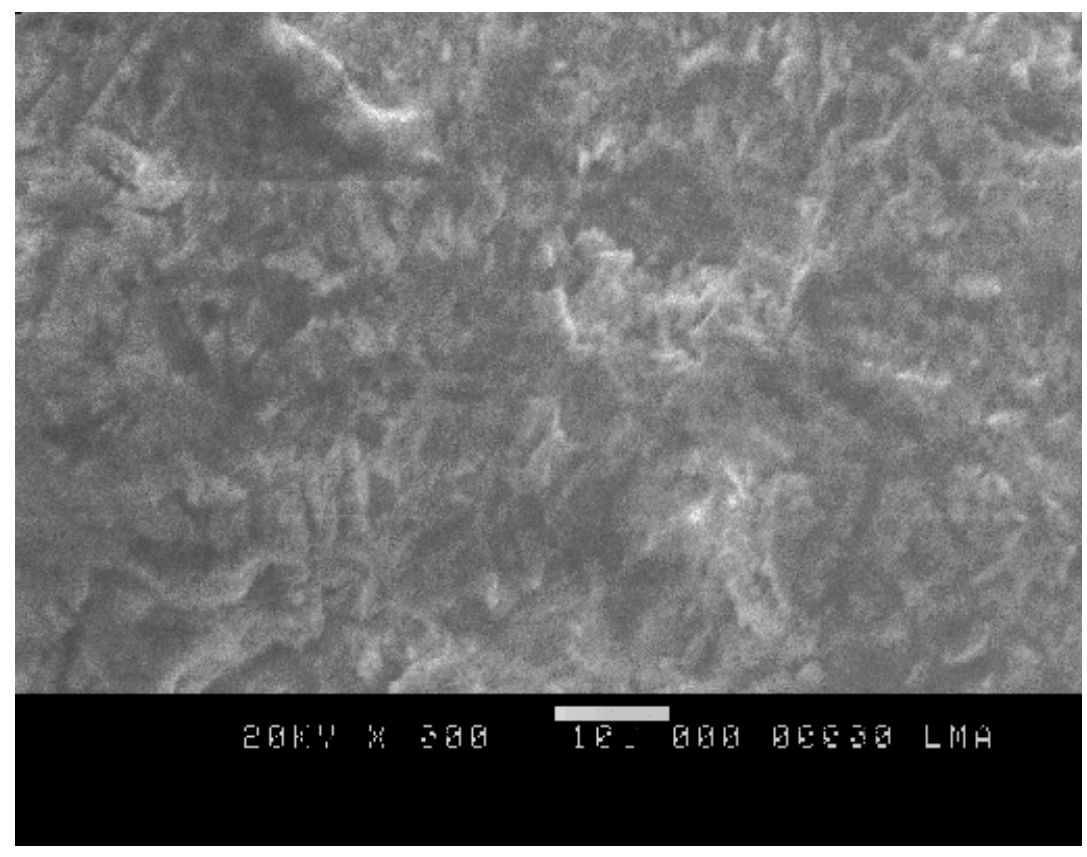

Figure 40 Alumina reinforced $\mathrm{Fe}_{3} \mathrm{Al}$ after erosion test X1400

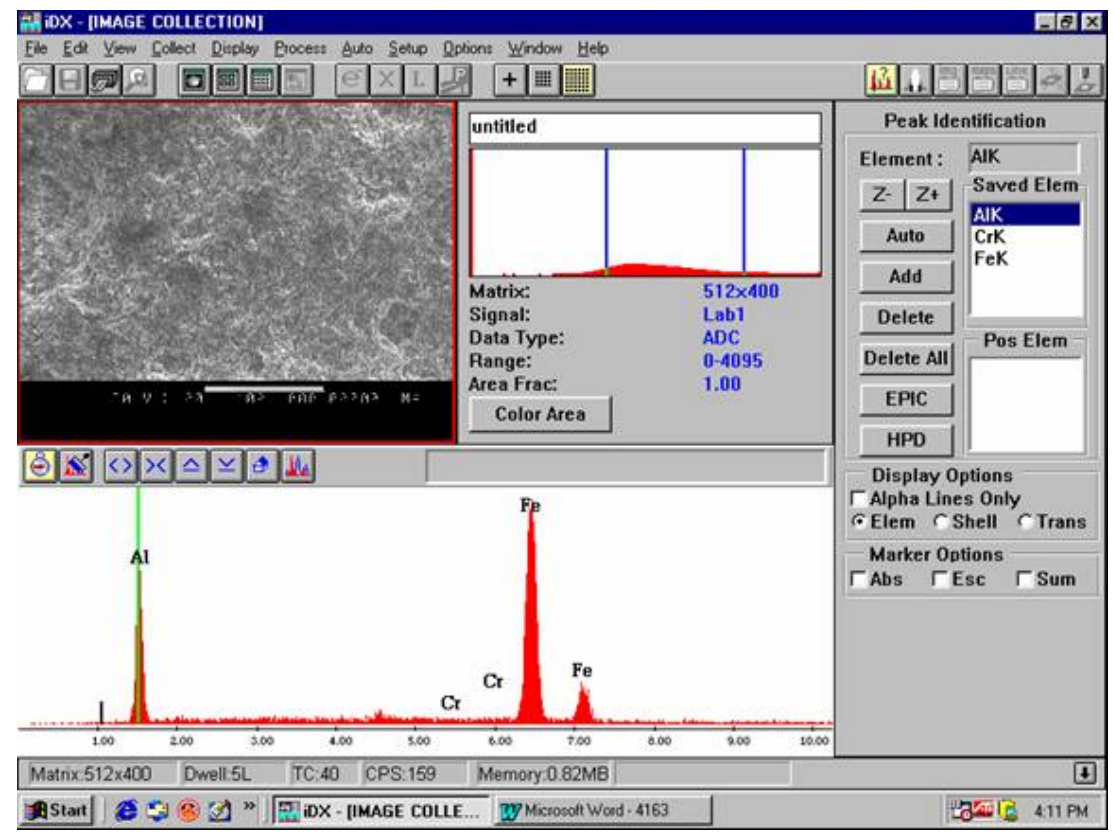

Figure 41: EDS analysis showing that alumina reinforced iron aluminide coating 
From the SEM microscopy and erosion test results it was concluded that the $\mathrm{Fe}_{3} \mathrm{Al}$ and alumina reinforced $\mathrm{Fe}_{3} \mathrm{Al}$ coating sprayed on IN 718 and $304 \mathrm{H}$ was adherent to substrate and did not delaminate during test. Erosion rate of alumina reinforced iron aluminide coating was higher than the iron aluminide coating sprayed on both substrate and erosion rate of plasma spray coating is higher than the HVOF coating. But once again both coating passed the erosion test

\section{Preparation of Oxidation, Carburization and Corrosion Test Samples:}

Thermal sprayed coatings were characterized for carburization, Oxidation, cyclic oxidation, sulfidation/corrosion and Erosion Test:

Uncoated IN 718, $304 \mathrm{H}$, steel , $\mathrm{Fe}_{3} \mathrm{Al}$ and alumina reinforced $\mathrm{Fe}_{3} \mathrm{Al}$ thermal Sprayed IN 718 and $304 \mathrm{H}$ samples were cut into small pieces. The samples five faces were covered with alumina paste, dried and only one face was exposed for oxidation, carburization and corrosion tests. Figure 42 to Figure 44 represent how samples were prepared with alumina paste and made ready for the oxidation, carburization and sulfidation/corrosion tests.

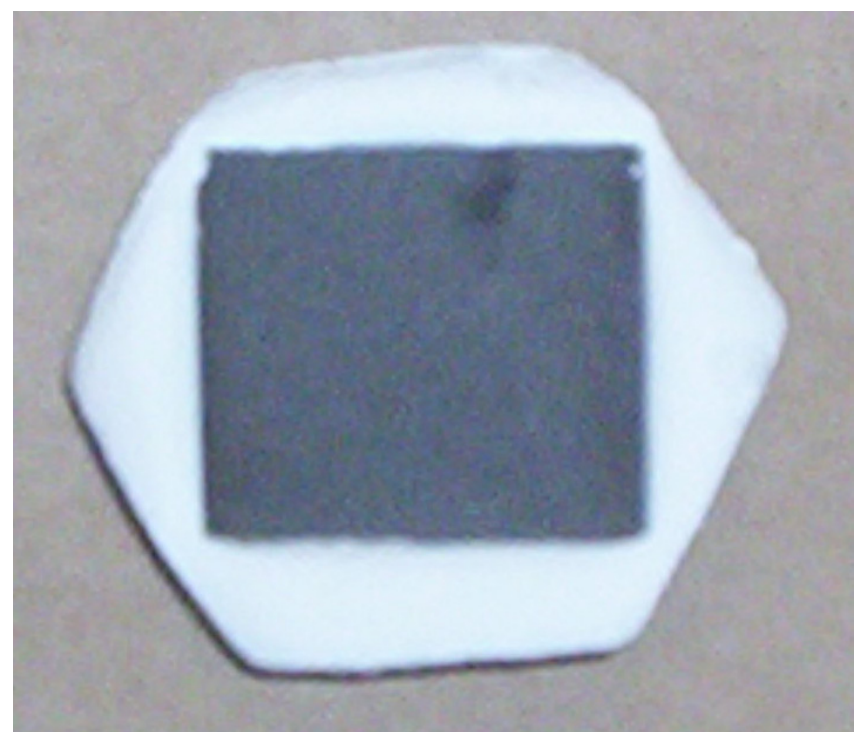

Figure 42: Showing Thermal Sprayed Exposed, other faces are covered in Alumina 


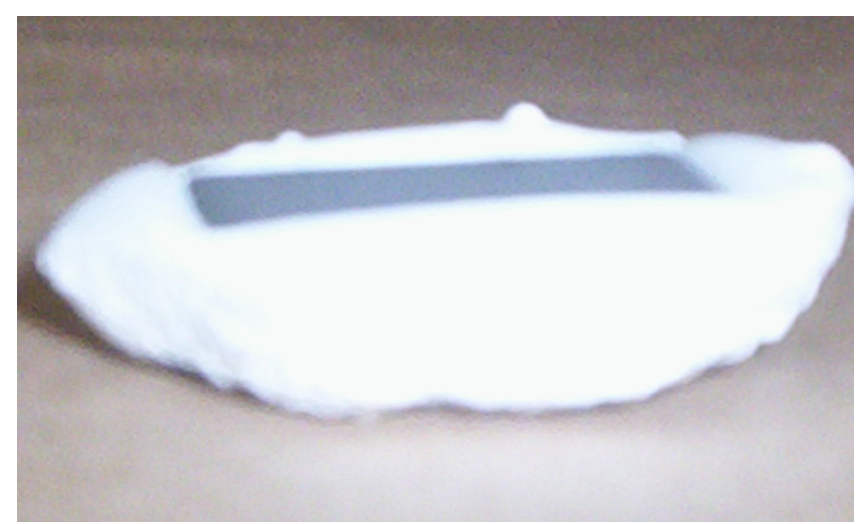

Figure 43: Side view show Thermal Sprayed Sample one face is open for exposure, other faces are covered in Alumina

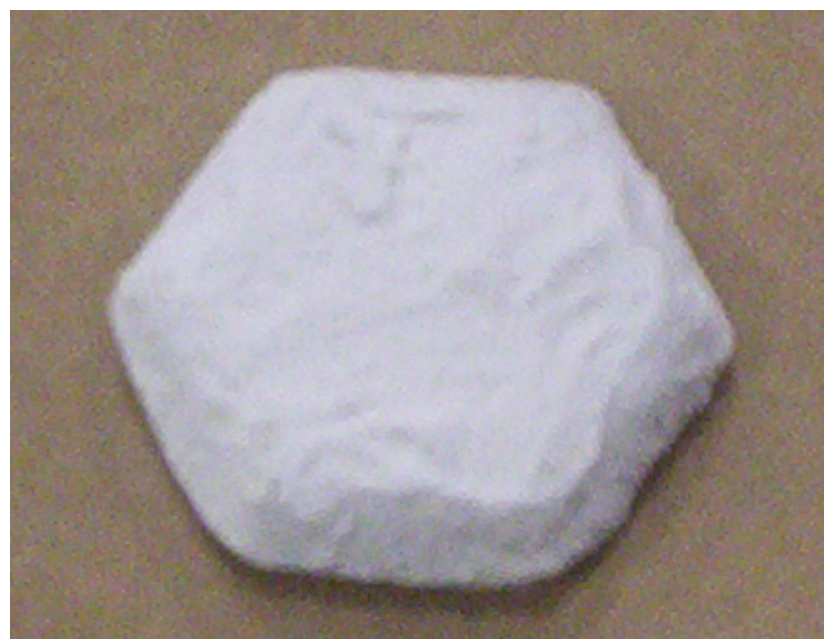

Figure 44: Side view show Thermal Sprayed Sample one face is exposed, other faces are covered in Alumina

Carburization resistance test was done in an atmosphere of hydrogen containing $2 \%$ methane by exposing the test samples at $1000 \mathrm{C}$ for 100 hours and weight gain $\left(\mathrm{mg} / \mathrm{cm}^{2}\right)$ with a function of time was compared with Incoloy 718, alloy $304 \mathrm{H}$. Figure 45 to 47 represents the test samples after carburization test. Table 15 represents the carburization test results. Results revealed that Thermal sprayed iron aluminide coating is a carburization resistant material

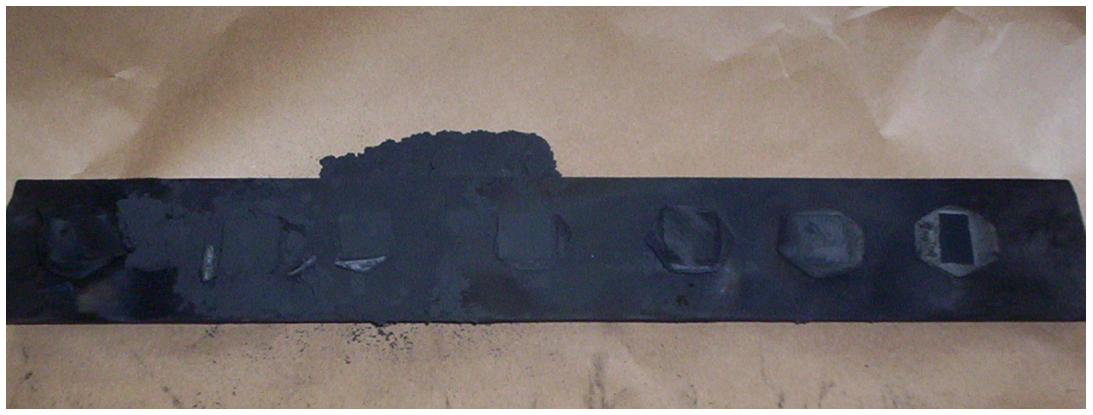

Figure 45: Free carbon deposited on samples after carburization 


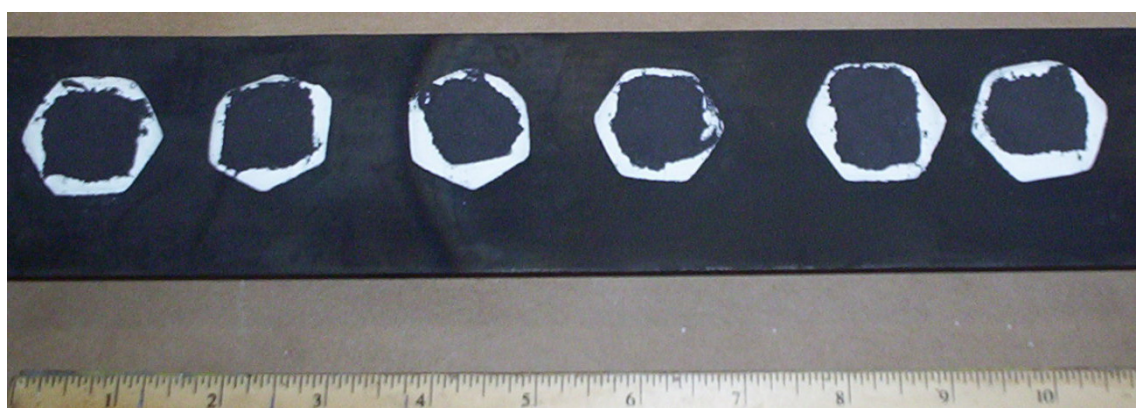

Figure 46: Uncoated and thermal sprayed Samples after Carburization tests

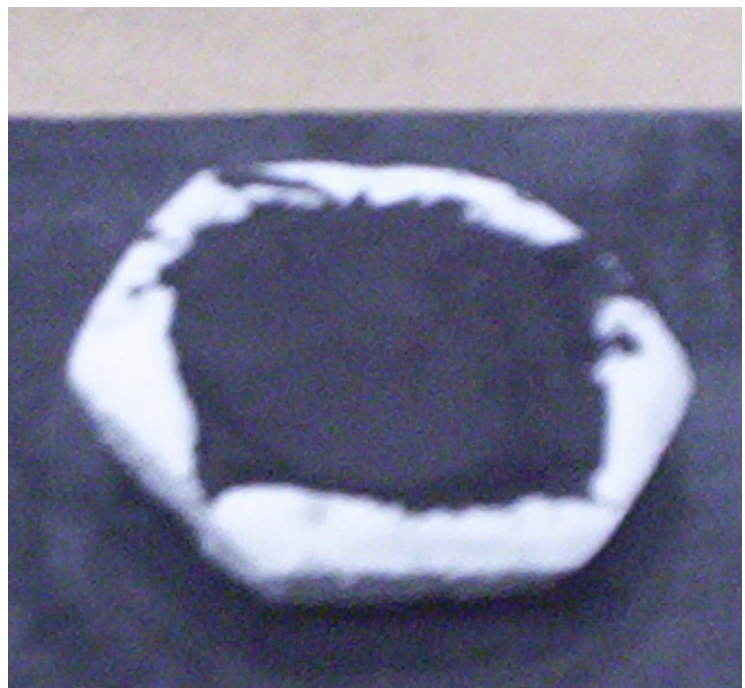

Figure 47: Showing free carbon accumulated on thermal sprayed tested sample

Table 15: Carburization Test Results of Fe3Al and Alumina Reinforced Fe3Al Coating on 304H and IN 718 Substrate

\begin{tabular}{|l|l|l|}
\hline Sample & $\begin{array}{l}\text { Type of Thermal Spray } \\
\text { Coating }\end{array}$ & $\begin{array}{l}\text { Weight Gain }\left(\mathrm{mg} / \mathrm{cm}^{2}\right) \text { after } \\
1000 \mathrm{Hrs} \text { Carburization at } \\
1000{ }^{\circ} \mathrm{C}\end{array}$ \\
\hline $\mathrm{Fe}_{3} \mathrm{Al}$ on $304 \mathrm{H}$ & 0.105 \\
\hline $\begin{array}{l}\text { Alumina reinforced } \mathrm{Fe}_{3} \mathrm{Al} \text { on } \\
304 \mathrm{H}\end{array}$ & Plasma Spray & 0.102 \\
\hline $\mathrm{Fe}_{3} \mathrm{Al}$ on 718 & Plasma Spray & 0.098 \\
\hline $\begin{array}{l}\text { Alumina reinforced } \mathrm{Fe}_{3} \mathrm{Al} \text { on } \\
718\end{array}$ & Plasma Spray & 0.097 \\
\hline $\mathrm{Fe}_{3} \mathrm{Al}$ on $304 \mathrm{H}$ & HVOF & 0.103 \\
\hline $\begin{array}{l}\text { Alumina reinforced } \mathrm{Fe} 3 \mathrm{Al} \text { on } \\
304 \mathrm{H}\end{array}$ & HVOF & 0.101 \\
\hline $\mathrm{Fe} 3 \mathrm{Al}$ on 718 & HVOF & 0.0975 \\
\hline $\begin{array}{l}\text { Alumina reinforced } \mathrm{Fe} 3 \mathrm{Al} \text { on } \\
718\end{array}$ & HVOF & 0.0965 \\
\hline Uncoated 718 & No Coating & 0.185 \\
\hline Uncoated 304 $\mathrm{H}$ & No Coating & 0.198 \\
\hline Steel & No coating & 0.255 \\
\hline &
\end{tabular}


From the carburization test results it was concluded that weight gain of uncoated steel, IN 718 and $304 \mathrm{H}$ were more than $\mathrm{Fe}_{3} \mathrm{Al}$ and alumina reinforced $\mathrm{Fe}_{3} \mathrm{Al}$ coating sprayed on IN 718 and $304 \mathrm{H}$. But still coatings were adherent to substrate, did not spall off during carburization test and the coating protected the substrate from the carburization. It was also found that there was little difference between carburization rate of alumina reinforced iron aluminide coating and the iron aluminide coating sprayed on both substrates by both the processes plasma spray and HVOF. But once again both coating showed carburization resistant properties and protected the substrate.

\section{Coal Ash Corrosion Test:}

Coal ash corrosion involves the reaction of alkali sulfate deposits that form an overlaying product on the metal surface. The reaction between the sulfates and the surrounding environment results in a liquid alkali-iron trisulfate (AIT) phase forming beneath the sulfate layer. This liquid phase has a high solubility for oxides (e.g. $\mathrm{Fe}_{\mathrm{x}} \mathrm{O}_{\mathrm{y}}, \mathrm{Al}_{\mathrm{x}} \mathrm{O}_{\mathrm{y}}, \mathrm{Ni}_{\mathrm{x}} \mathrm{O}_{\mathrm{y}}$ ), is in direct contact with the metal surface and performs a fluxing breakdown of the protective scale. The synthetic ash that has been labeled as the worst case is the one composed of $25 \mathrm{wt} \% \quad \mathrm{Fe}_{2} \mathrm{O}_{3}-37.5 \quad \mathrm{wt} \% \quad \mathrm{Na}_{2} \mathrm{SO}_{4}-37.5 \quad$ wt $\% \quad \mathrm{~K}_{2} \mathrm{SO}_{4}$. This particular composition is composed solely of corrodents that are used in the AIT reaction.

Uncoated $304 \mathrm{H}$, IN718 and steel sample, $\mathrm{Fe}_{3} \mathrm{Al}$ and alumina reinforced $\mathrm{Fe}_{3} \mathrm{Al}$ thermal sprayed (Plasma and HVOF) coating on $304 \mathrm{H}$ and IN 718 were exposed with $\mathrm{Fe}_{2} \mathrm{O}_{3}-37.5$ wt $\% \mathrm{Na}_{2} \mathrm{SO}_{4}-37.5 \mathrm{wt} \% \mathrm{~K}_{2} \mathrm{SO}_{4}$ slag at $1000{ }^{\circ} \mathrm{C}$ for 100 hours. Uncoated $304 \mathrm{H}$, IN 718 steel sample was severly attacked by the slag, But Fe3Al and alumina reinforced sprayed sample substrate was not attacked but coating was partially attacked but it still protected the underneath substrate. Figure 48 to figure 50 represent photographs of test samples after corrosion tests

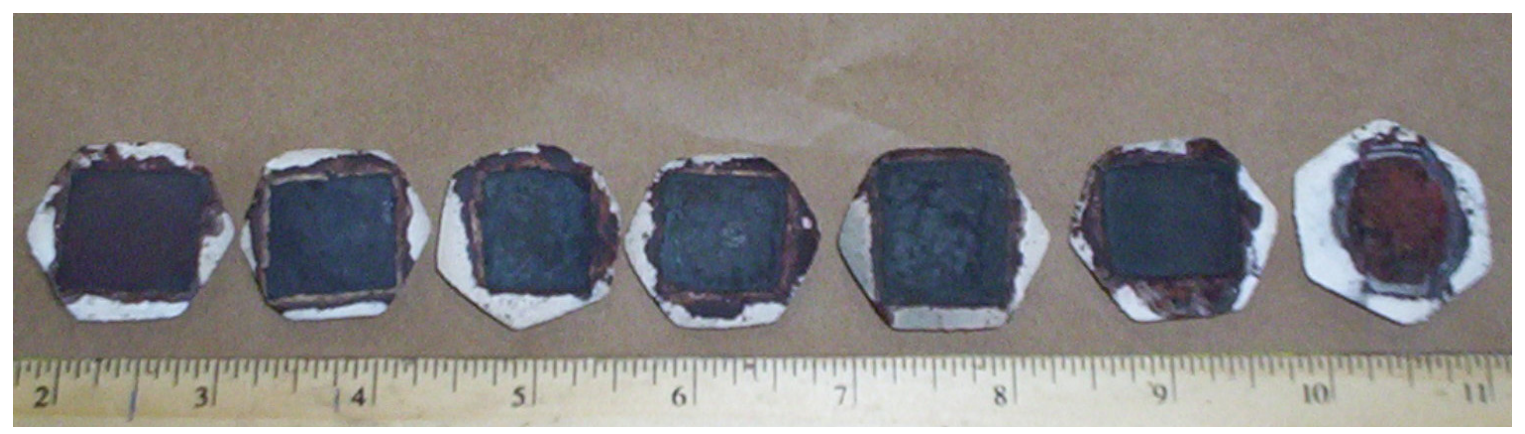

Figure 48: Showing Samples after Corrosion Tests in presence of $\mathrm{Fe}_{2} \mathrm{O}_{3}-37.5 \mathrm{wt} \%$ $\mathrm{Na}_{2} \mathrm{SO}_{4}-37.5 \mathrm{wt} \% \mathrm{~K}_{2} \mathrm{SO}_{4}$ for 100 Hours at $1000{ }^{\circ} \mathrm{C}$ 


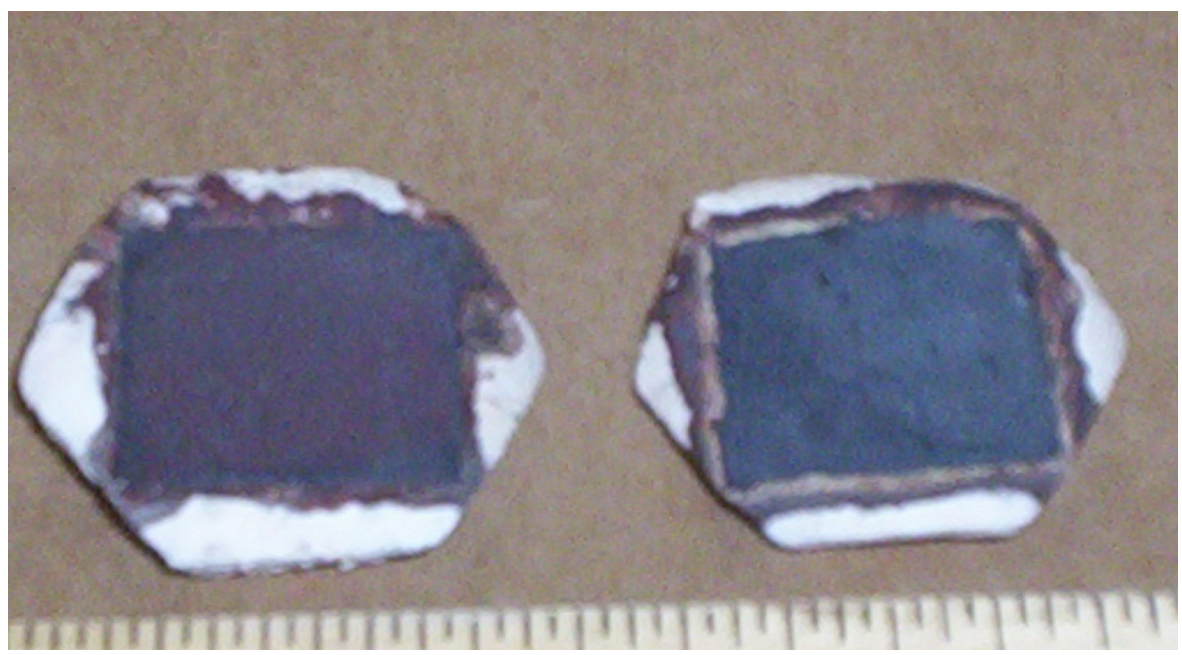

Figure 49:Showing thermal sprayed alumina reinforced $\mathrm{Fe}_{3} \mathrm{Al}$ and $\mathrm{Fe}_{3} \mathrm{Al} 304 \mathrm{H}$ partially attacked by this $\mathrm{Fe}_{2} \mathrm{O}_{3}, \mathrm{~K}_{2} \mathrm{SO}_{4}, \mathrm{Na}_{2} \mathrm{SO}_{4}$ but alumina reinforced $\mathrm{Fe}_{3} \mathrm{Al}$ showed better property.

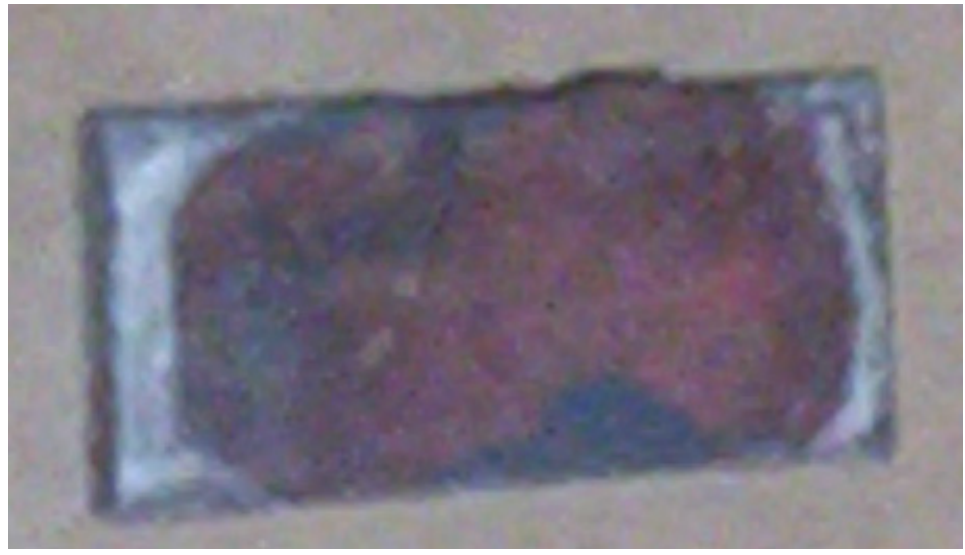

Figure 50: Showing uncoated $304 \mathrm{H}$ severely attacked by this $\mathrm{Fe}_{2} \mathrm{O}_{3}, \mathrm{~K}_{2} \mathrm{SO}_{4}, \mathrm{Na}_{2} \mathrm{SO}_{4}$

Table 16 represents the samples appearances after corrosion tests and figure 51 to $55 \mathrm{~A}$ represent SEM and EDS analysis of corroded uncoated and thermal sprayed coating samples. 


\section{Table 16: Corrosion Test Results of $\mathrm{Fe}_{3} \mathrm{Al}$ and Alumina Reinforced Fe3Al Coating on $304 \mathrm{H}$ and IN 718 Substrate}

\begin{tabular}{|l|l|l|}
\hline Sample & $\begin{array}{l}\text { Type of Thermal Spray } \\
\text { Coating }\end{array}$ & Corrosion Attack \\
\hline $\mathrm{Fe}_{3} \mathrm{Al}$ on $304 \mathrm{H}$ & Plasma Spray & $\begin{array}{l}\text { Partial corrosion on coating } \\
\text { but no corrosion on the } \\
\text { substrate }\end{array}$ \\
\hline $\begin{array}{l}\text { Alumina reinforced } \mathrm{Fe}_{3} \mathrm{Al} \text { on } \\
304 \mathrm{H}\end{array}$ & Plasma Spray & $\begin{array}{l}\text { Partial corrosion on coating } \\
\text { but no corrosion on the } \\
\text { substrate }\end{array}$ \\
\hline $\mathrm{Fe}_{3} \mathrm{Al}$ on 718 & Plasma Spray & $\begin{array}{l}\text { Partial corrosion on coating } \\
\text { butno corrosion on the } \\
\text { substrate }\end{array}$ \\
\hline $\begin{array}{l}\mathrm{Alumina} \text { reinforced } \mathrm{Fe}_{3} \mathrm{Al} \text { on } \\
718\end{array}$ & Plasma Spray & $\begin{array}{l}\text { Partial corrosion on coating } \\
\text { butno corrosion on the } \\
\text { substrate }\end{array}$ \\
\hline $\mathrm{Fe}_{3} \mathrm{Al}$ on $304 \mathrm{H}$ & $\begin{array}{l}\text { Partial corrosion on coating } \\
\text { butno corrosion on the } \\
\text { substrate }\end{array}$ \\
\hline $\begin{array}{l}\text { Alumina reinforced } \mathrm{Fe}_{3} \mathrm{Al} \text { on } \\
304 \mathrm{H}\end{array}$ & HVOF & $\begin{array}{l}\text { Partial corrosion on coating } \\
\text { butno corrosion on the } \\
\text { substrate }\end{array}$ \\
\hline Fe $\mathrm{Al}_{3}$ on 718 & $\begin{array}{l}\text { Partial corrosion on coating } \\
\text { butno corrosion on the } \\
\text { substrate }\end{array}$ \\
\hline $\begin{array}{l}\text { Alumina reinforced } \mathrm{Fe}_{3} \mathrm{Al} \text { on } \\
718\end{array}$ & HVOF & $\begin{array}{l}\text { Partial corrosion on coating } \\
\text { butno corrosion on the } \\
\text { substrate }\end{array}$ \\
\hline Uncoated 718 & HVOF & $\begin{array}{l}\text { Severe attack, corroded } 718 \\
\text { Severe attack, corroded 304 } \mathrm{H}\end{array}$ \\
\hline Uncoated $304 \mathrm{H}$ & $\begin{array}{l}\text { Severe attack, corroded and } \\
\text { crumbled }\end{array}$ \\
\hline Steel & No coating & \\
\hline
\end{tabular}




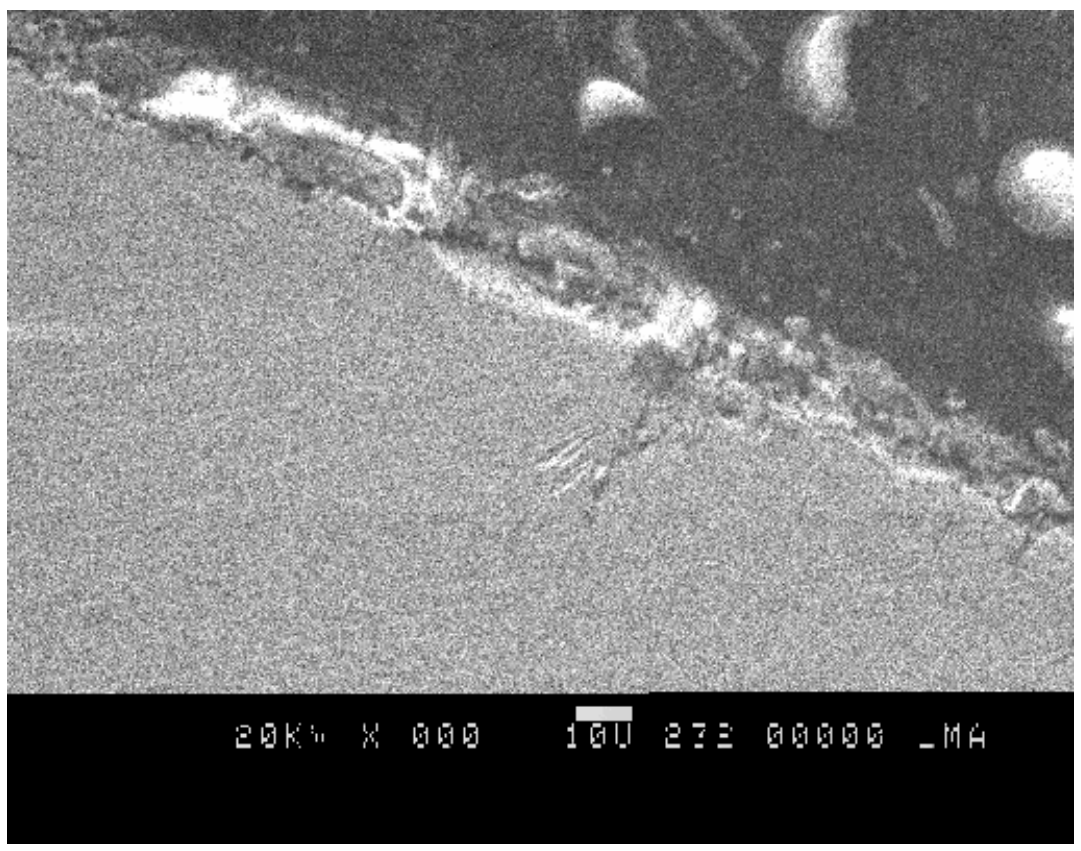

Figure 51: SEM micrograph showing uncoated $304 \mathrm{H}$ is corroded and layer is falling off

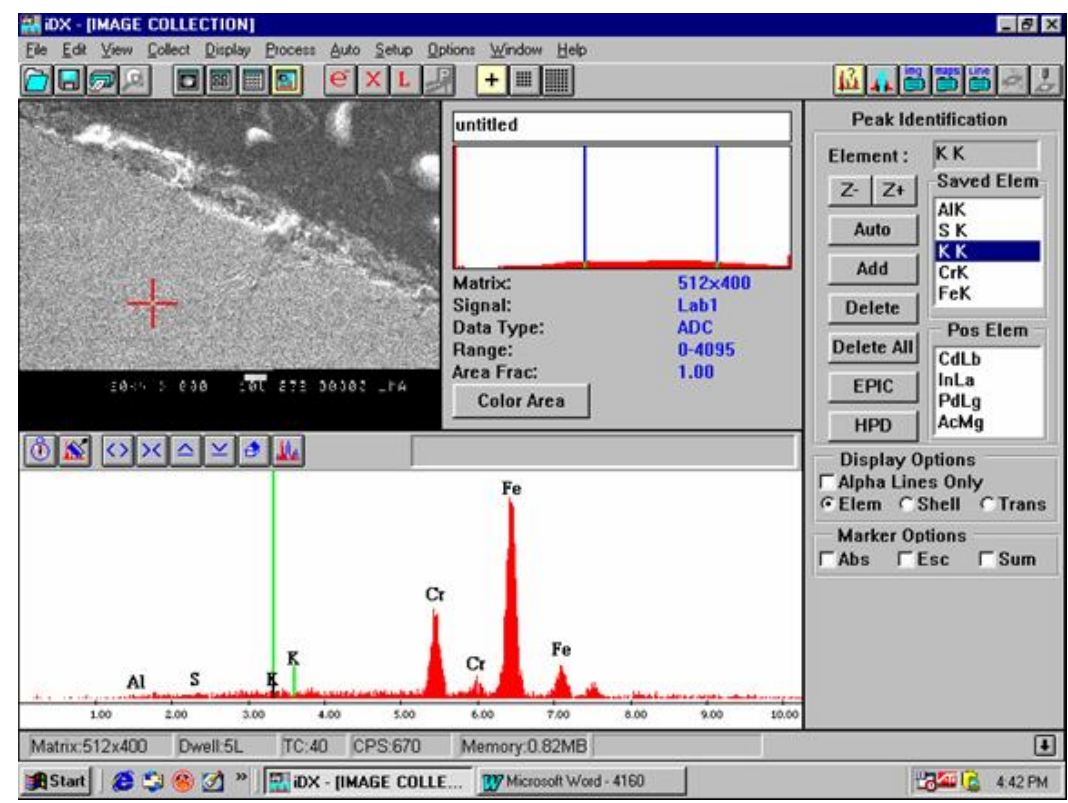

Figure 52: EDS analysis Showing under the corroded layer is comprised of iron and chromium $-304 \mathrm{H}$ 


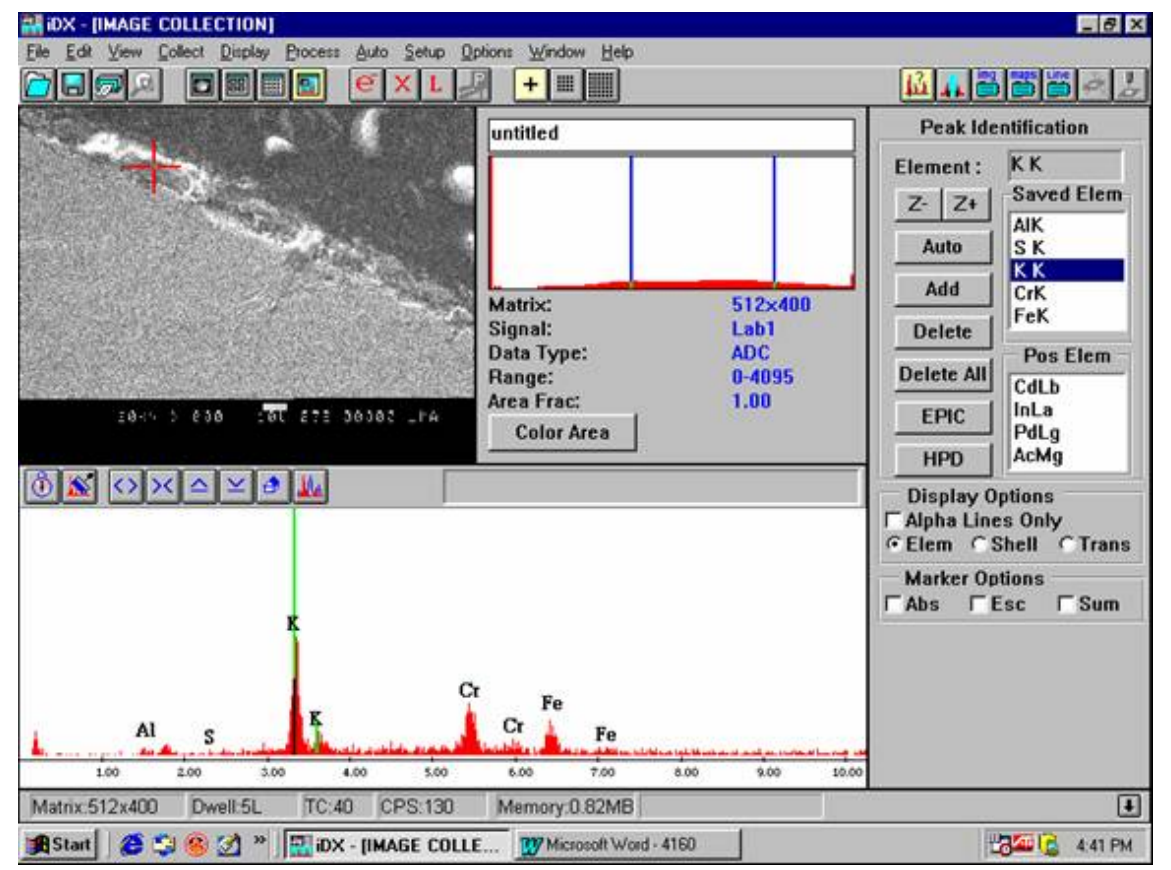

Figure 53 Showing that uncoated $304 \mathrm{H}$ surface was attacked by $\mathrm{K}_{2} \mathrm{SO}_{4}$ and $\mathrm{Na}_{2} \mathrm{SO}_{4}$

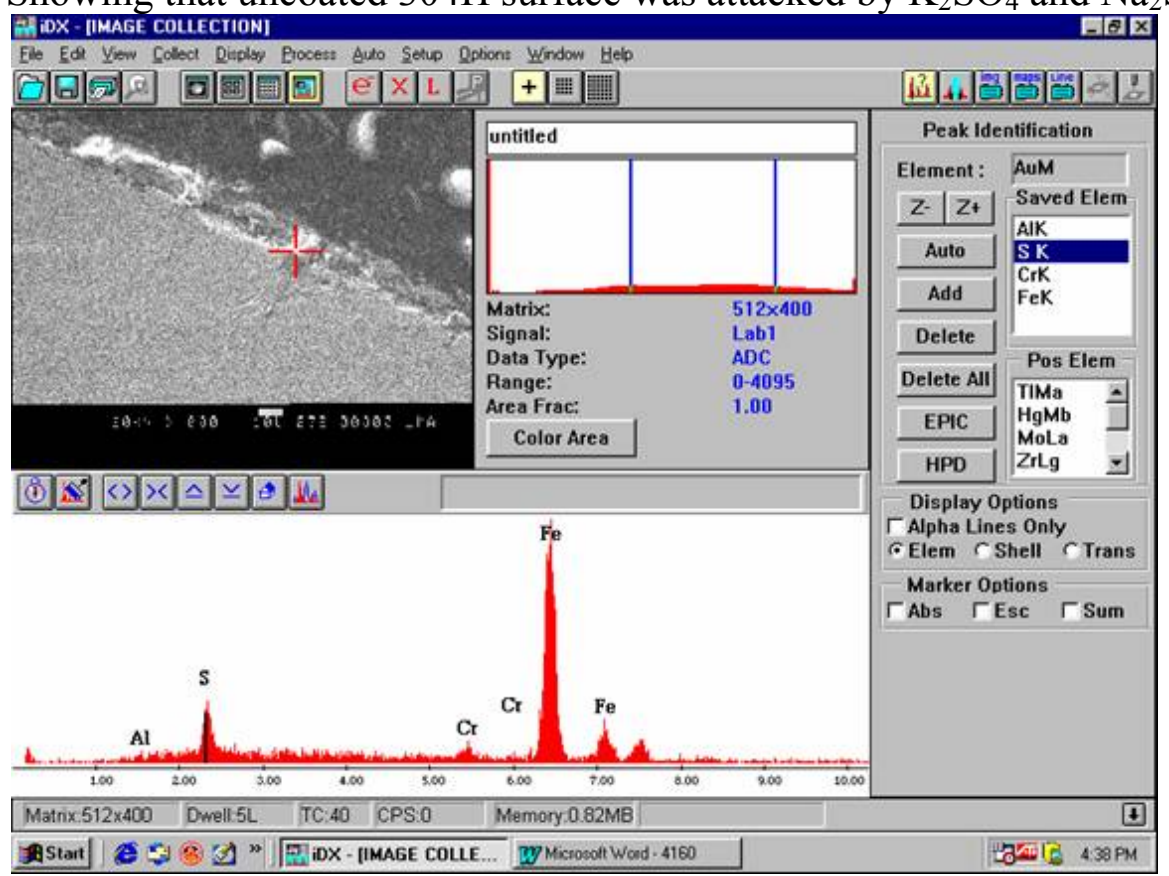

Figure 54: Showing that uncoated $304 \mathrm{H}$ surface was attacked by $\mathrm{K}_{2} \mathrm{SO}_{4}$ and $\mathrm{Na}_{2} \mathrm{SO}_{4}$ 


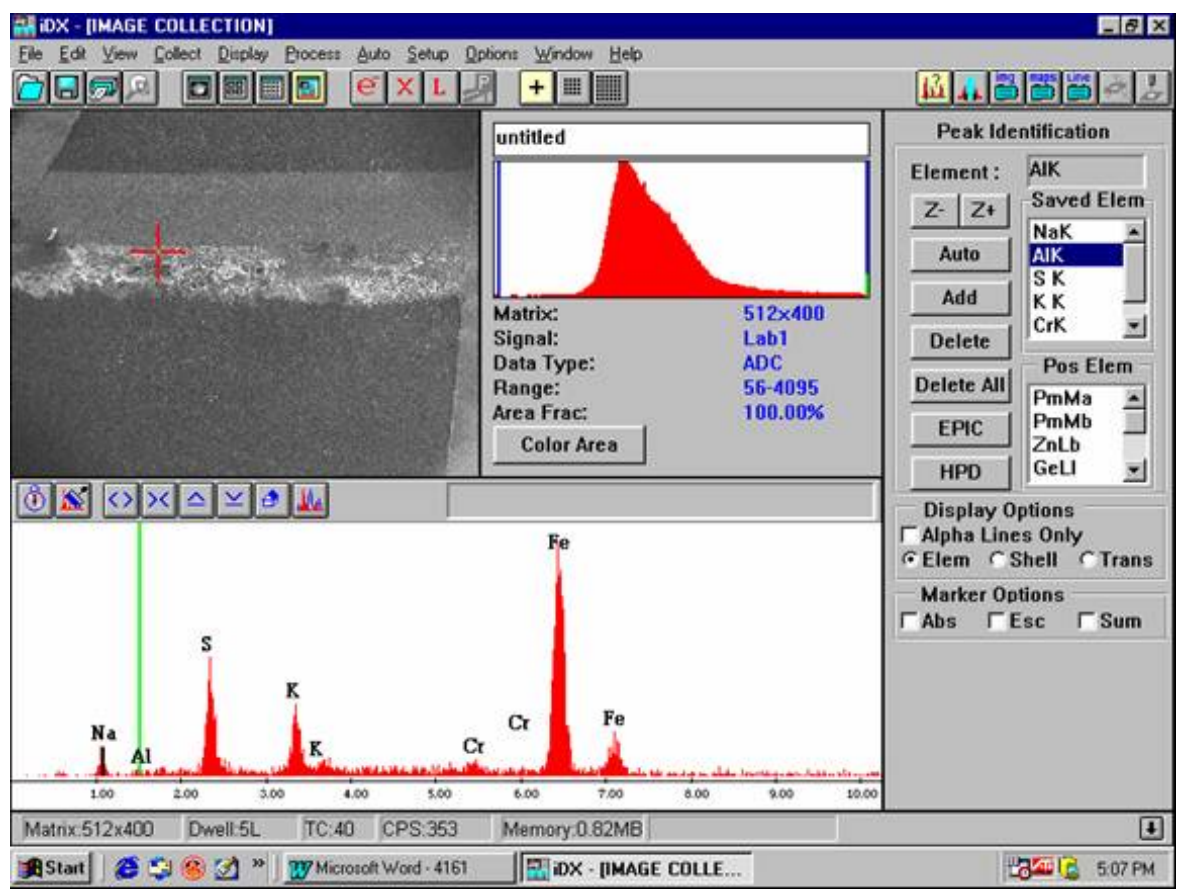

Figure 55: Showing thermal sprayed alumina reinforced $\mathrm{Fe}_{3} \mathrm{Al}$ on $304 \mathrm{H}$ partially attacked by this $\mathrm{Fe}_{2} \mathrm{O}_{3}, \mathrm{~K}_{2} \mathrm{SO}_{4}, \mathrm{Na}_{2} \mathrm{SO}_{4}$ but coating remains intact and underneath layer was not attacked

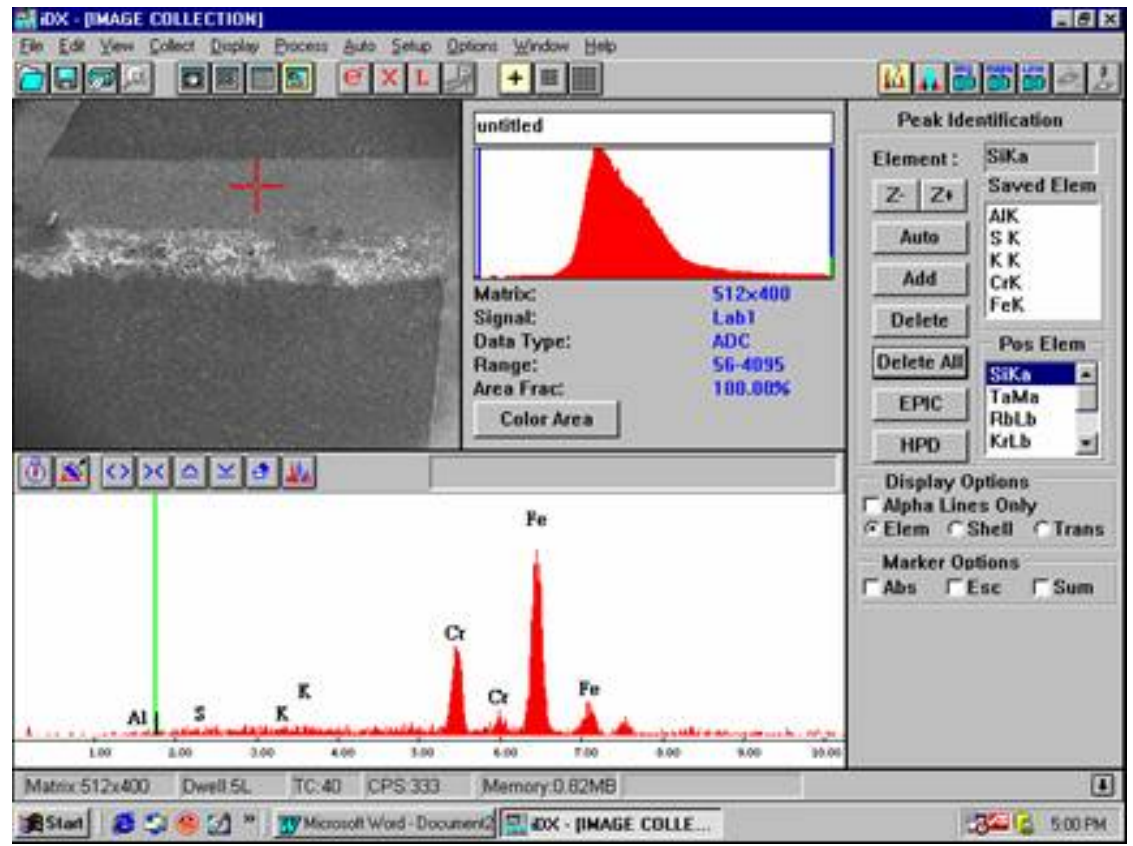

Figure 55A: Showing thermal sprayed alumina reinforced $\mathrm{Fe}_{3} \mathrm{Al}$ on $304 \mathrm{H}$ partially attacked by this $\mathrm{Fe}_{2} \mathrm{O}_{3}, \mathrm{~K}_{2} \mathrm{SO}_{4}, \mathrm{Na}_{2} \mathrm{SO}_{4}$ but coating remains intact and underneath layer was not attacked EDS analysis showing only $\mathrm{Fe}, \mathrm{Cr}$ 
From the SEM microscopy and corrosion test results it was concluded that uncoated steel, IN 718 and $304 \mathrm{H}$ were severely attacked by this alkali slag, But $\mathrm{Fe}_{3} \mathrm{Al}$ and alumina reinforced $\mathrm{Fe}_{3} \mathrm{Al}$ coating sprayed on IN 718 and 304H were also partially attacked by this slag. But still coatings were adherent to substrate, did not spall off during corrosion test and the coating protected the substrate from the slag reaction. It was also found that corrosion rate of alumina reinforced iron aluminide coating was lower than the iron aluminide coating sprayed on both substrate and corrosion rate of plasma spray coating was higher than the HVOF coating. But once again both coating showed corrosion resistant properties and protected the substrate.

Oxidation Testing: Cyclic Oxidation testing was done on alumina reinforced $\mathrm{Fe}_{3} \mathrm{Al}$ Sprayed, $\mathrm{Fe}_{3} \mathrm{Al}$ sprayed 304H, IN718, uncoated 718, $304 \mathrm{H}$ and mild steel in atmosphere of air containing $5 \% \quad \mathrm{H}_{2} \mathrm{O}$. Temperature was cycled between $1000^{\circ} \mathrm{C}$ and room temperature for 100 hours. The specimens was evaluated for weight change, scale morphology and microscopy. Figure 56 to 57 represent alumina reinforced $\mathrm{Fe}_{3} \mathrm{Al}$ Sprayed, $\mathrm{Fe}_{3} \mathrm{Al}$ sprayed 304H, IN718, uncoated 718, $304 \mathrm{H}$ and mild steel Samples after Cyclic Oxidation Tests and oxidation test profile. Figure 58 to Figure 83 represent SEM micrograph of alumina reinforced $\mathrm{Fe}_{3} \mathrm{Al}$ Sprayed, $\mathrm{Fe}_{3} \mathrm{Al}$ sprayed coating and uncoated $304 \mathrm{H}$ substrate after oxidation tests
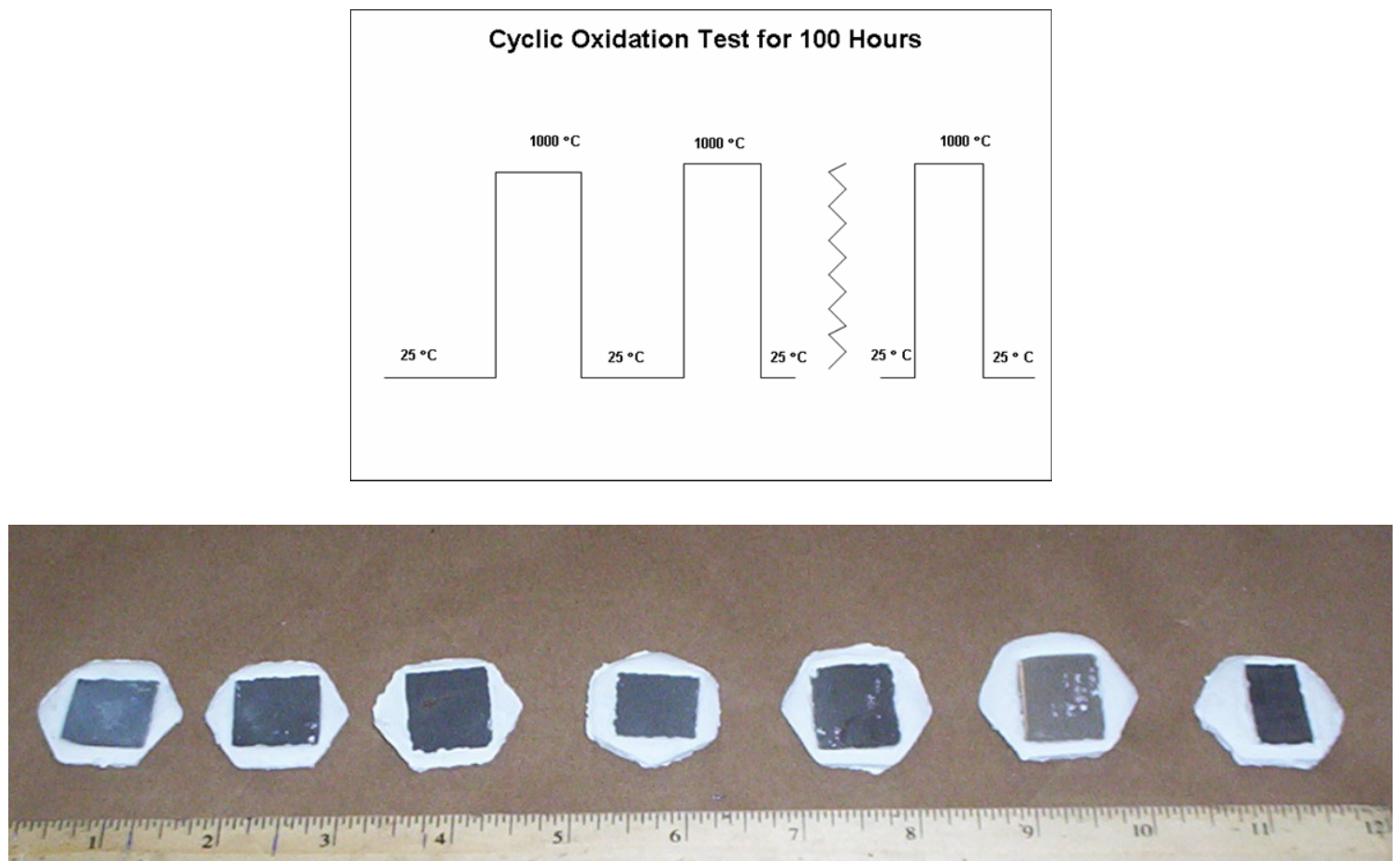

Figure 56: Showing alumina reinforced $\mathrm{Fe}_{3} \mathrm{Al}$ Sprayed, $\mathrm{Fe}_{3} \mathrm{Al}$ sprayed 304H, IN718 , uncoated 718, $304 \mathrm{H}$ and mild steel Samples after Cyclic Oxidation Tests and oxidation test profile 


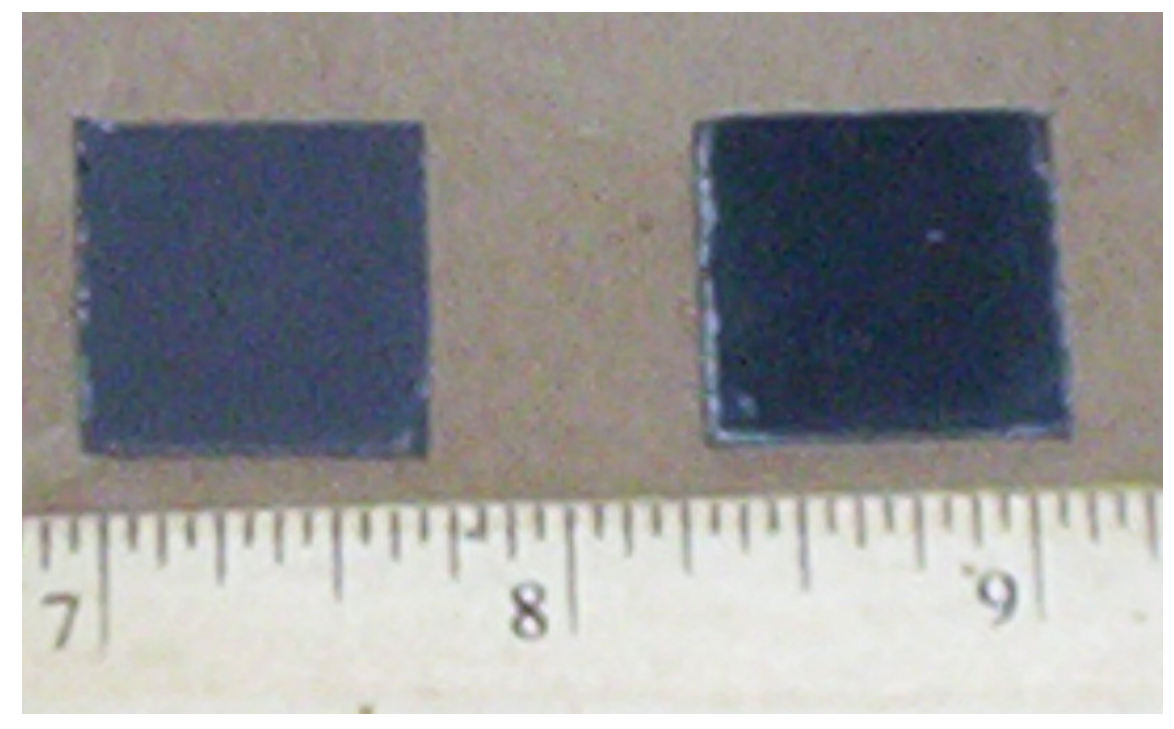

Figure 57: Showing Alumina Reinforced $\mathrm{Fe}_{3} \mathrm{Al}$ Sprayed coating is lighter in color than $\mathrm{Fe}_{3} \mathrm{Al}$ Sprayed Samples after Cyclic Oxidation Tests. Weight gain is less incase of alumina reinforced thermal sprayed $\mathrm{Fe}_{3} \mathrm{Al}$ coating. But coating remained intact after oxidation tests for both $\mathrm{Fe}_{3} \mathrm{Al}$ coating and alumina reinforced $\mathrm{Fe}_{3} \mathrm{Al}$ coating

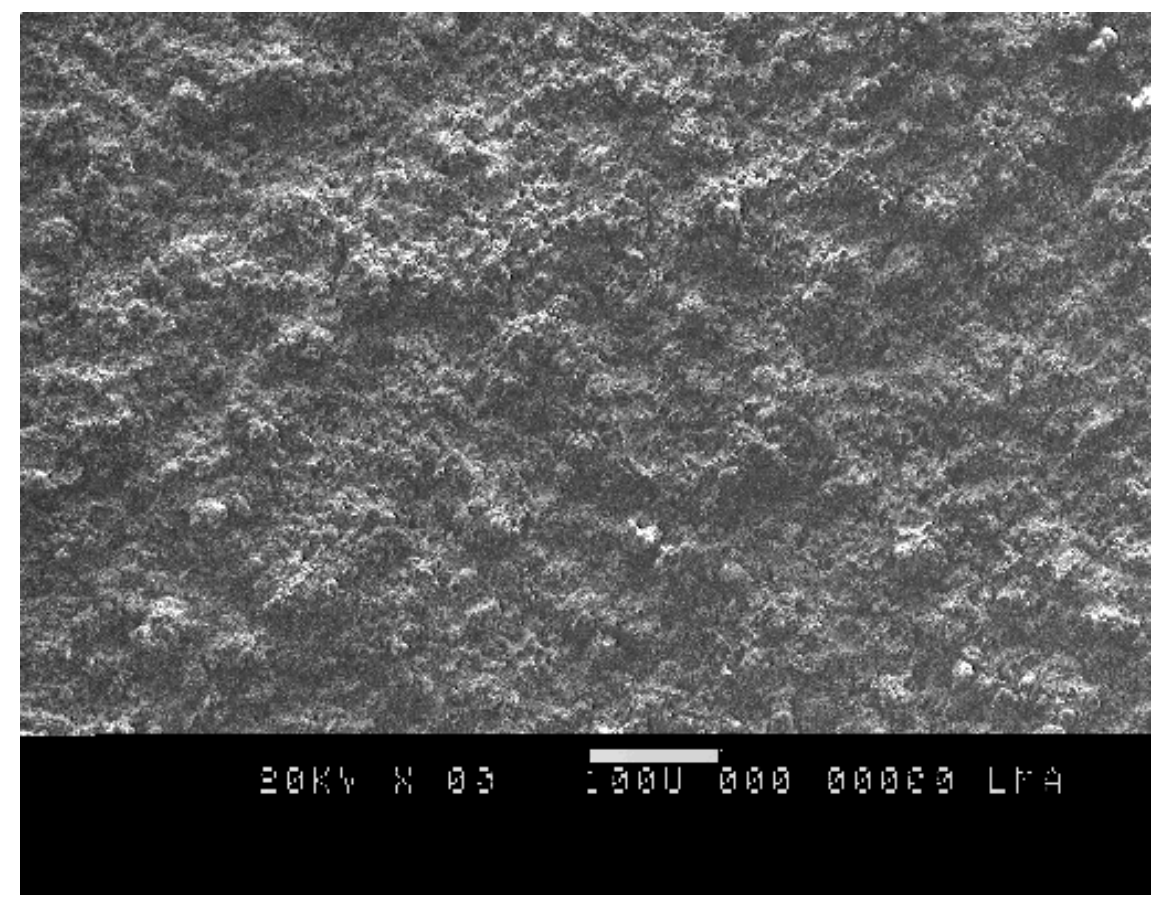

Figure 58: SEM Micrograph showing morphology of as sprayed $\mathrm{Fe}_{3} \mathrm{Al}$ coating on $304 \mathrm{H}$ before oxidation test X150 


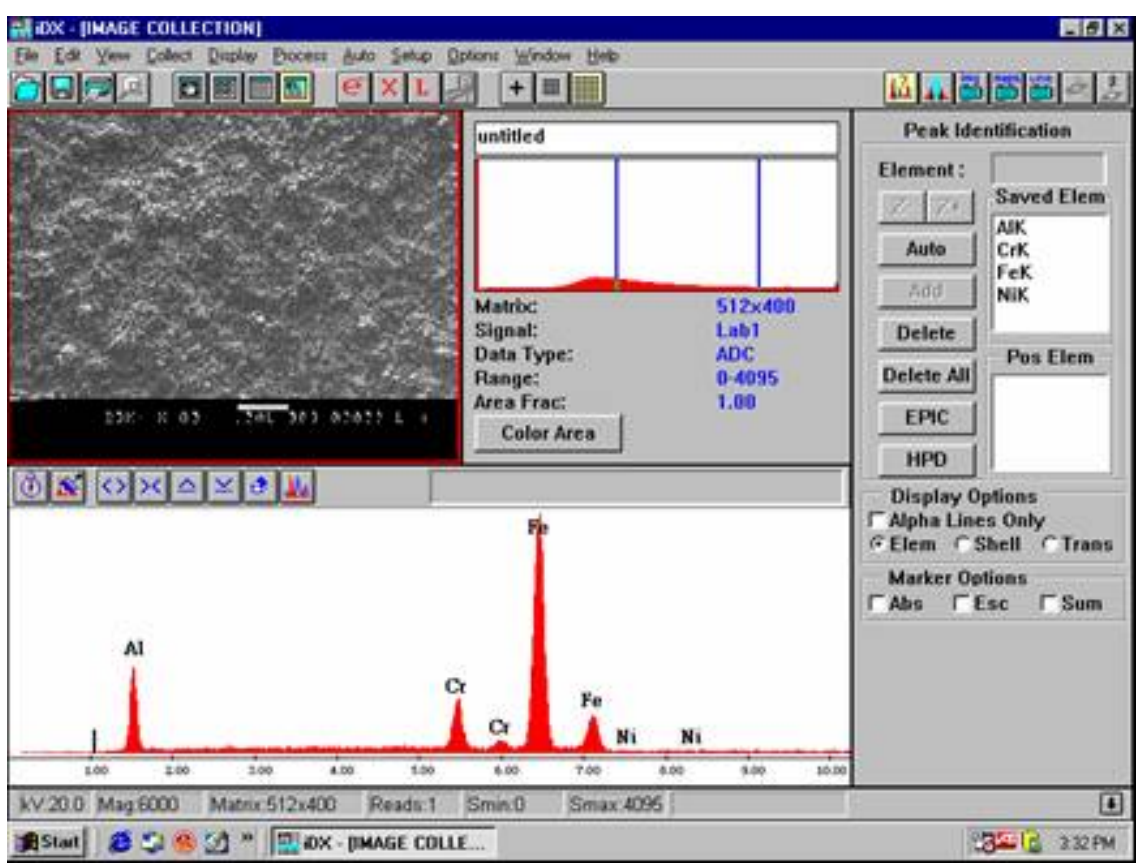

Figure 59: $\mathrm{EDS}$ analysis show $\mathrm{Fe}$ and $\mathrm{Al}$ from $\mathrm{Fe}_{3} \mathrm{Al}$. $\mathrm{Cr}$ is from original powders

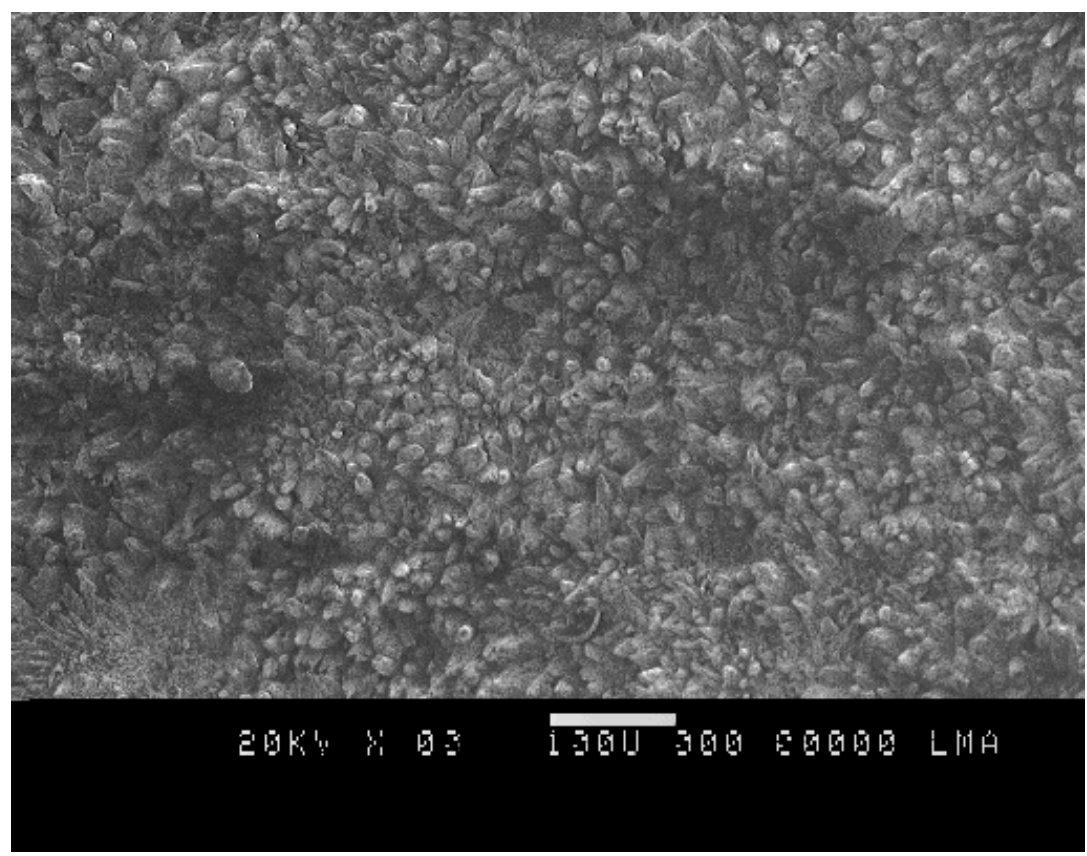

Figure 60: SEM Micrograph of $\mathrm{Fe}_{3} \mathrm{Al}$ sprayed on $304 \mathrm{H}$ after the cyclic oxidation test. Figure show some change in morphology but coating showed enough adhesion to protect underneath substrate $\mathrm{X} 150$ 


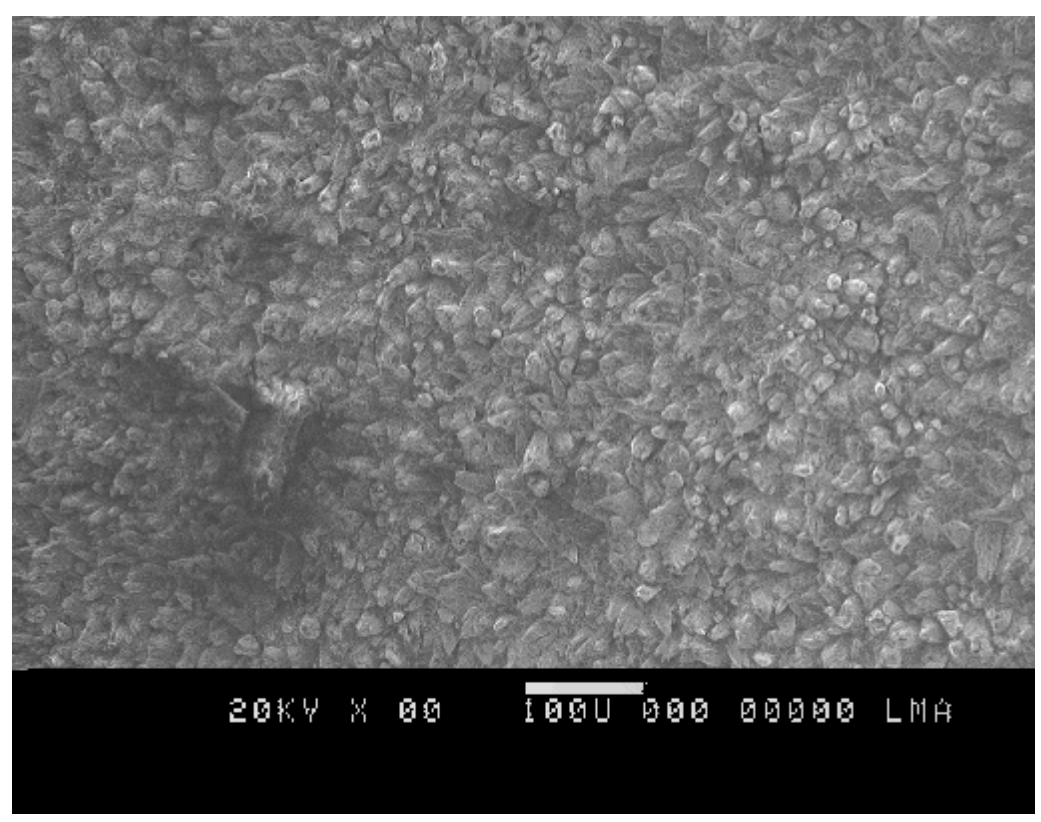

Figure 61: SEM Micrograph of $\mathrm{Fe}_{3} \mathrm{Al}$ sprayed on $304 \mathrm{H}$ after the cyclic oxidation test. Figure show some change in morphology but coating showed enough adhesion to protect underneath substrate $\mathrm{X} 150$

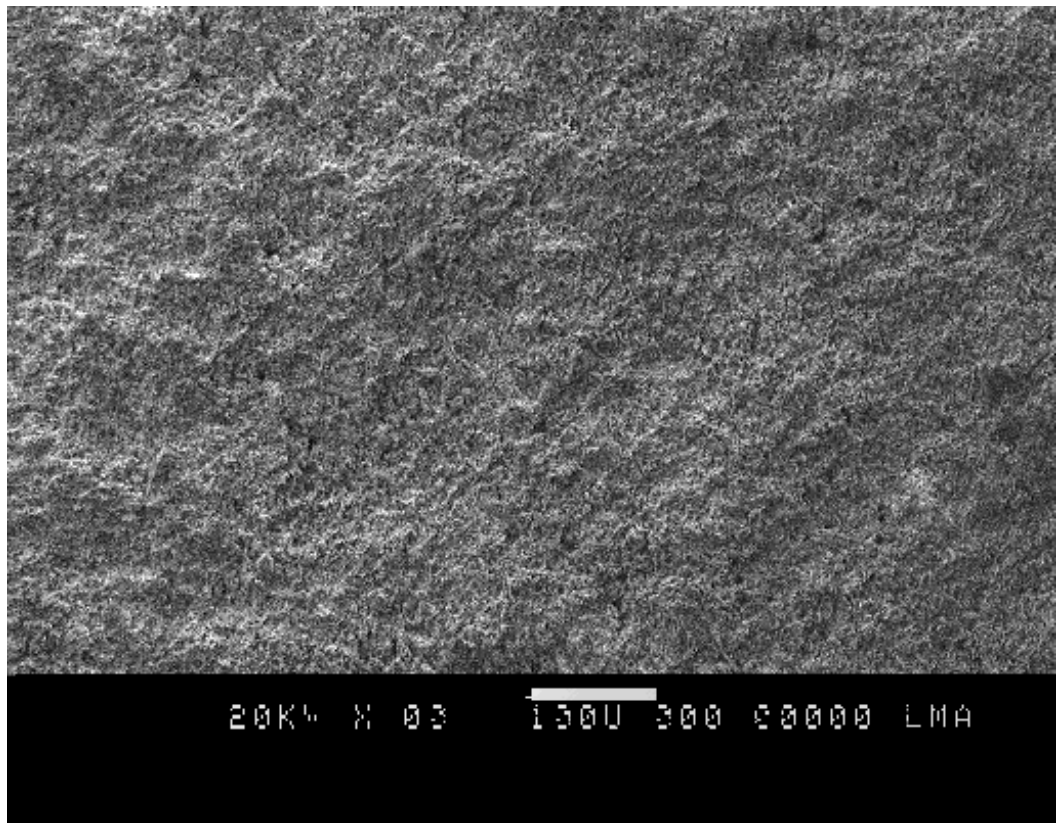

Figure 62: Top oxidized layers were removed underneath oxidized layer showing same morphology like before the test X150 


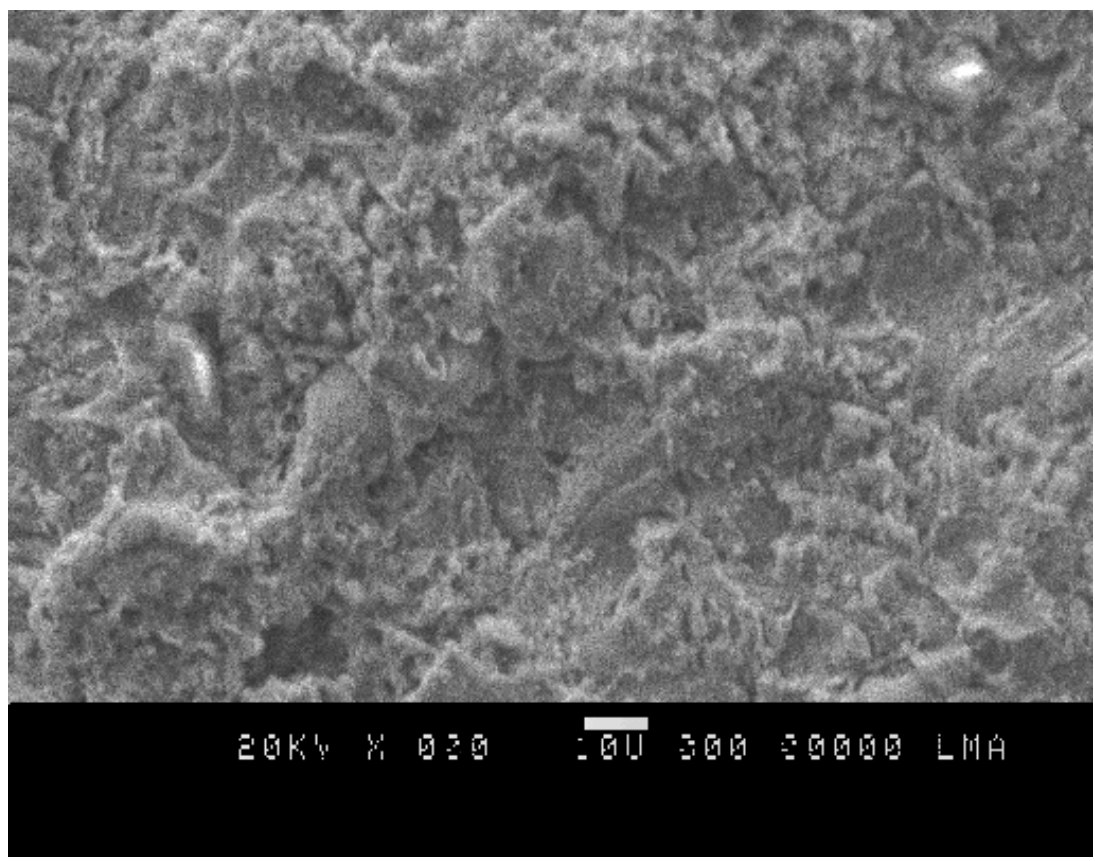

Figure 63: Showing Oxidized layers were removed under the top layer X800

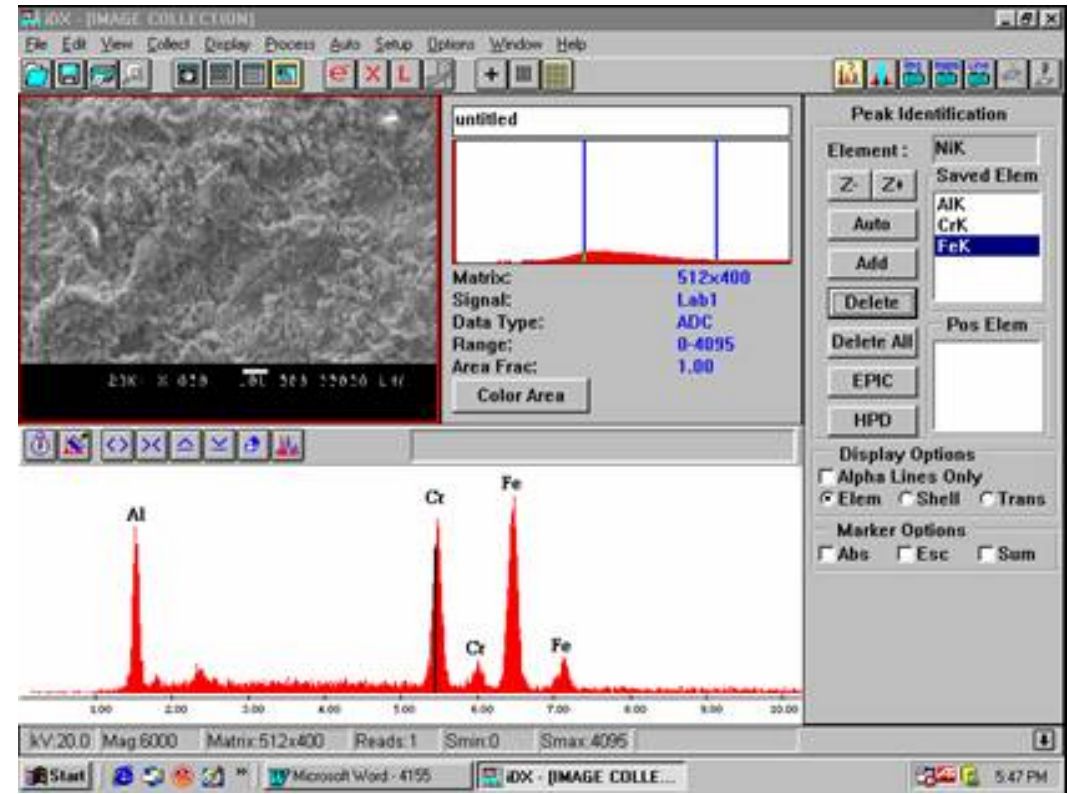

Figure 64: EDS analysis represent $\mathrm{Fe}_{3} \mathrm{Al}$ Coating protecting underneath substrate 


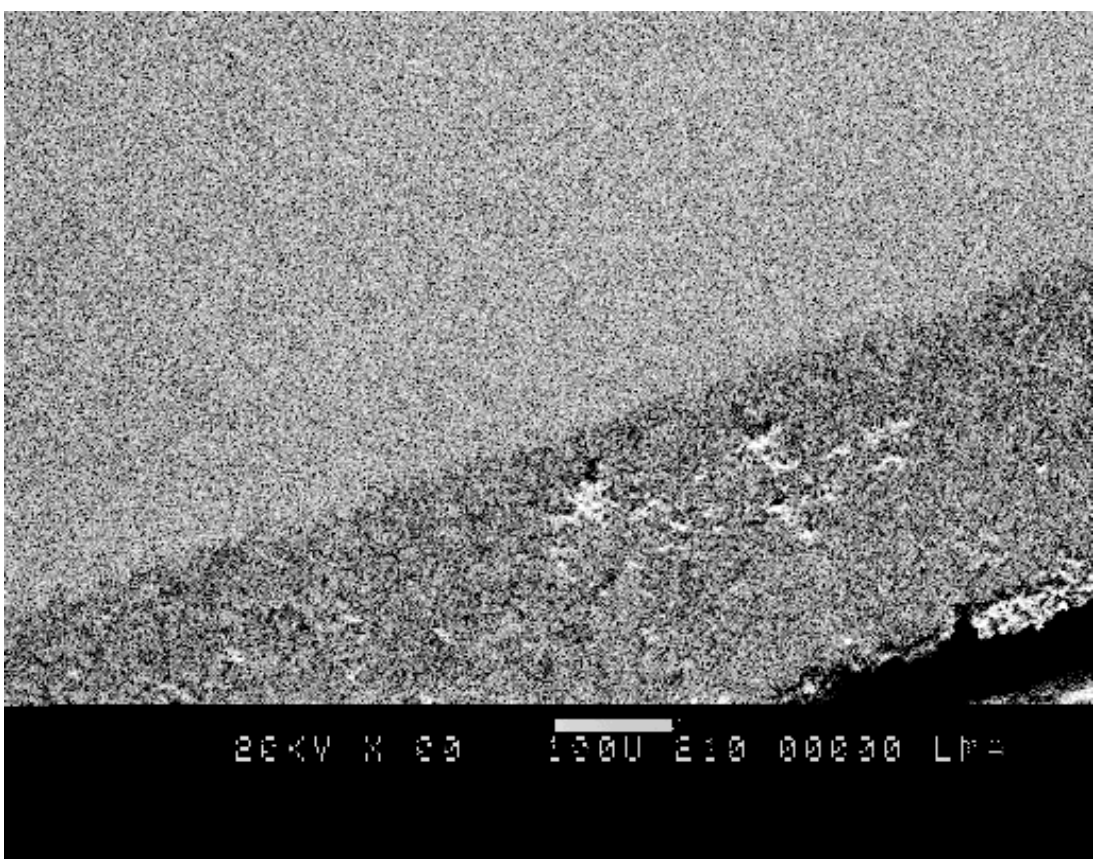

Figure 65: Cross section of the coating represent 10-20 micron thermal $\mathrm{Fe}_{3} \mathrm{Al}$ sprayed layers were oxidized after cyclic oxidation test but remaining thermal sprayed layer was not attacked and protected $304 \mathrm{H}$ substrate

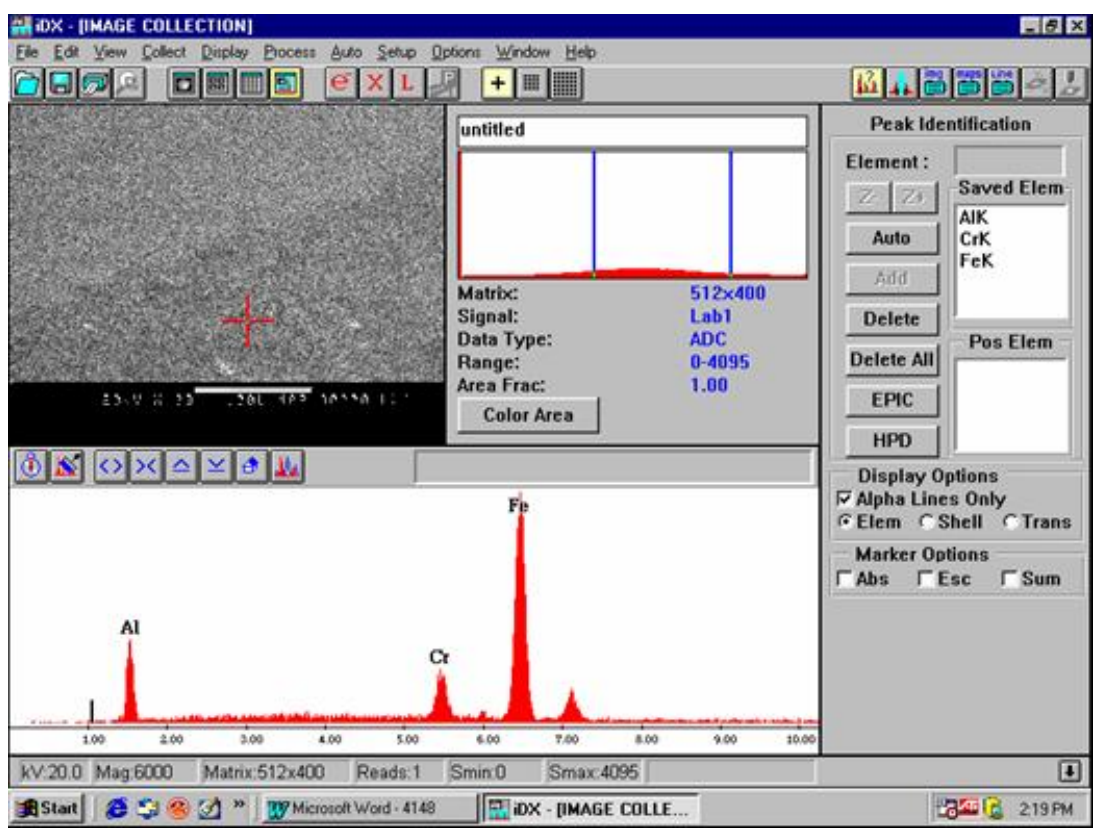

Figure 66: EDS analysis of coating after the oxidation test show Fe, Al, Cr which is similar to before oxidation test 


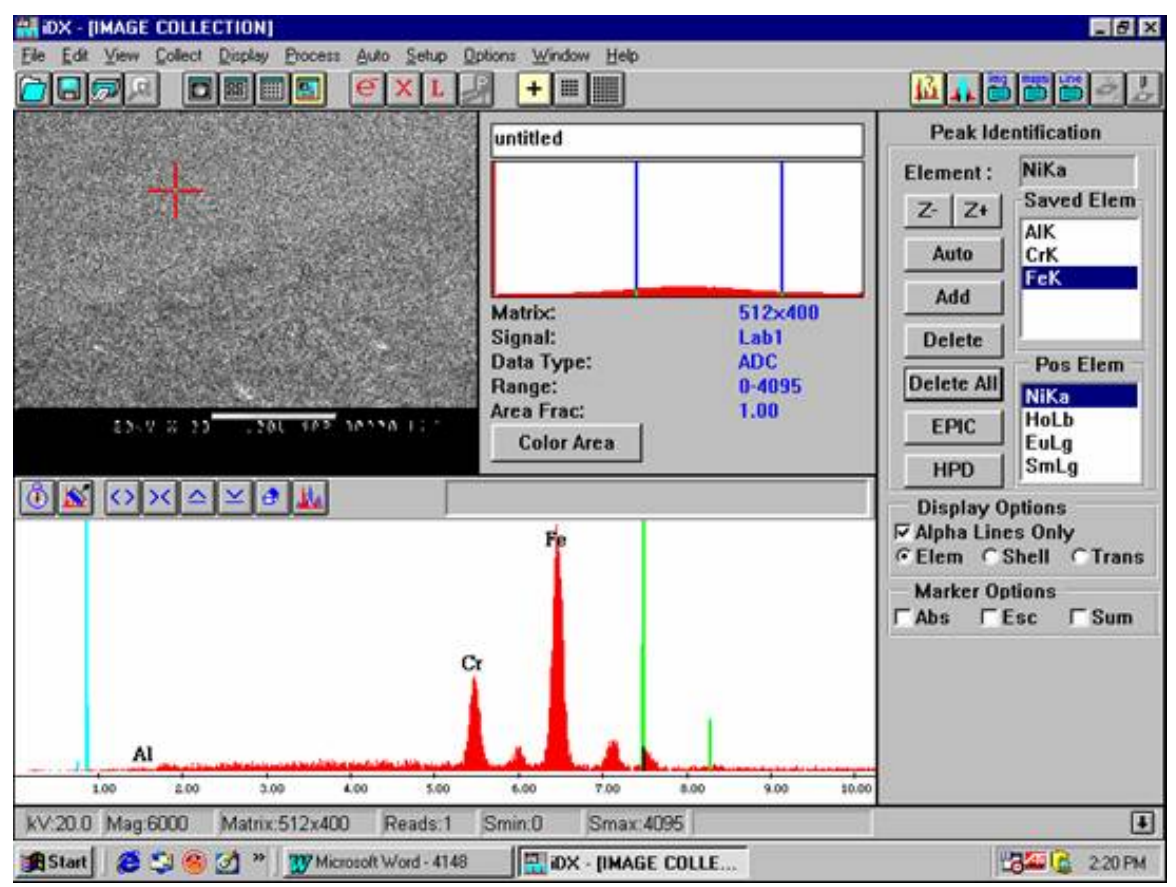

Figure 67: EDS analysis showing only $\mathrm{Fe}$ and $\mathrm{Cr}$ in the $304 \mathrm{H}$ substrate.

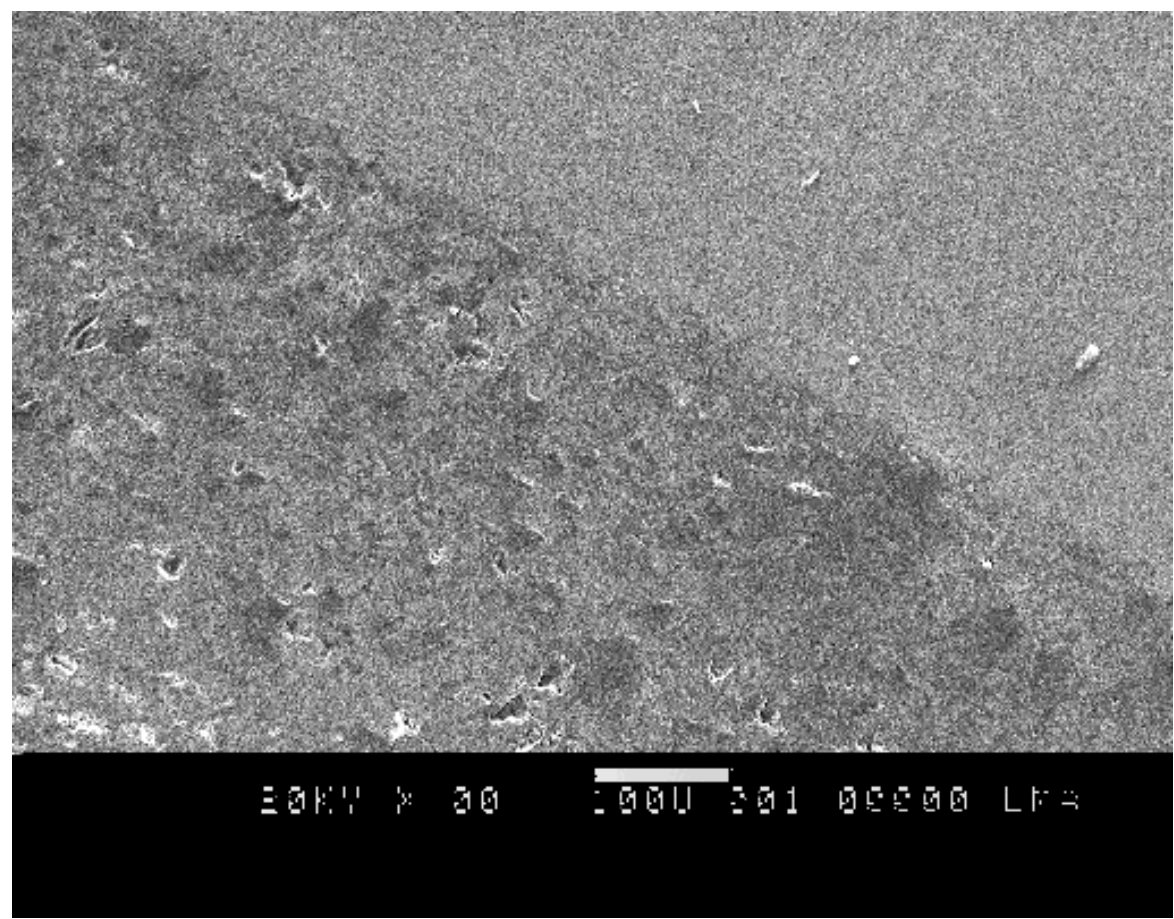

Figure 68: Alumina reinforced iron aluminide coating on $304 \mathrm{H}$ after oxidation test showing nicely bonded with substrate and protecting the substrate from oxidation X150 


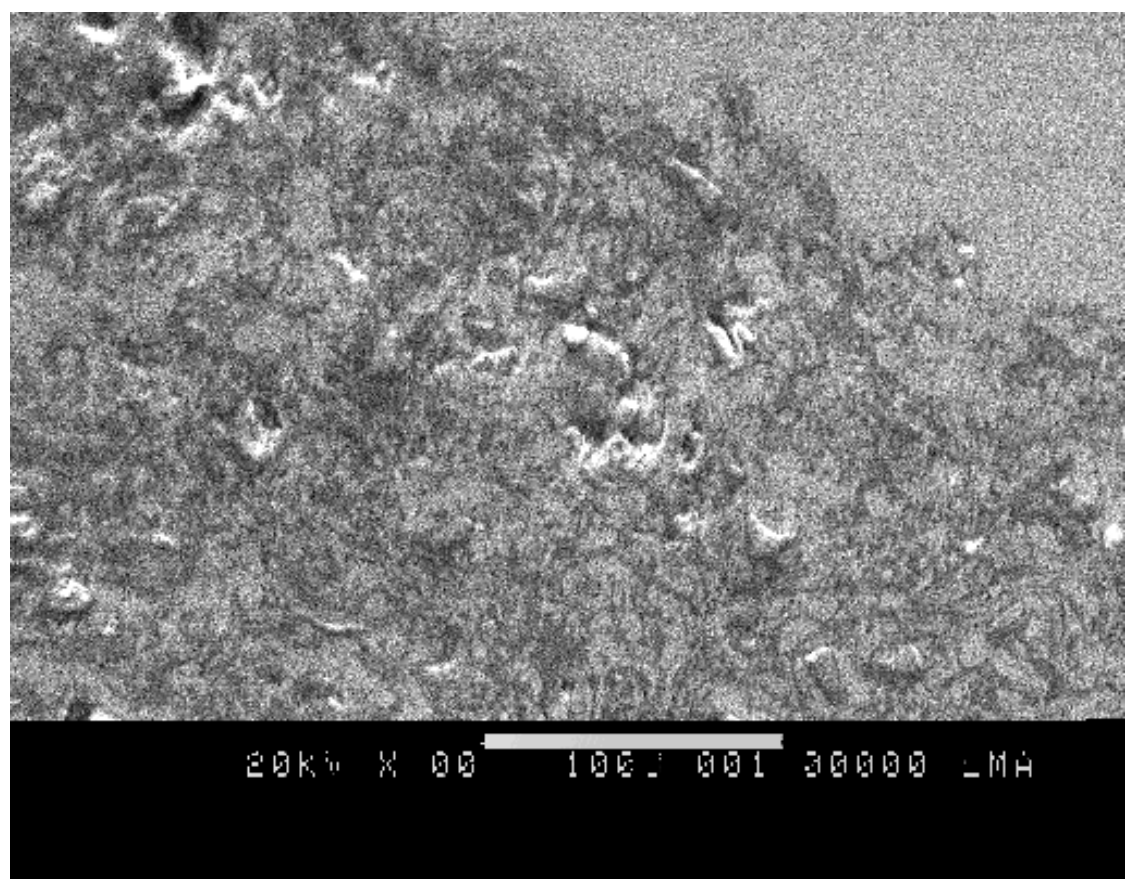

Figure 69: Alumina reinforced iron aluminide coating on $304 \mathrm{H}$ after oxidation test X350

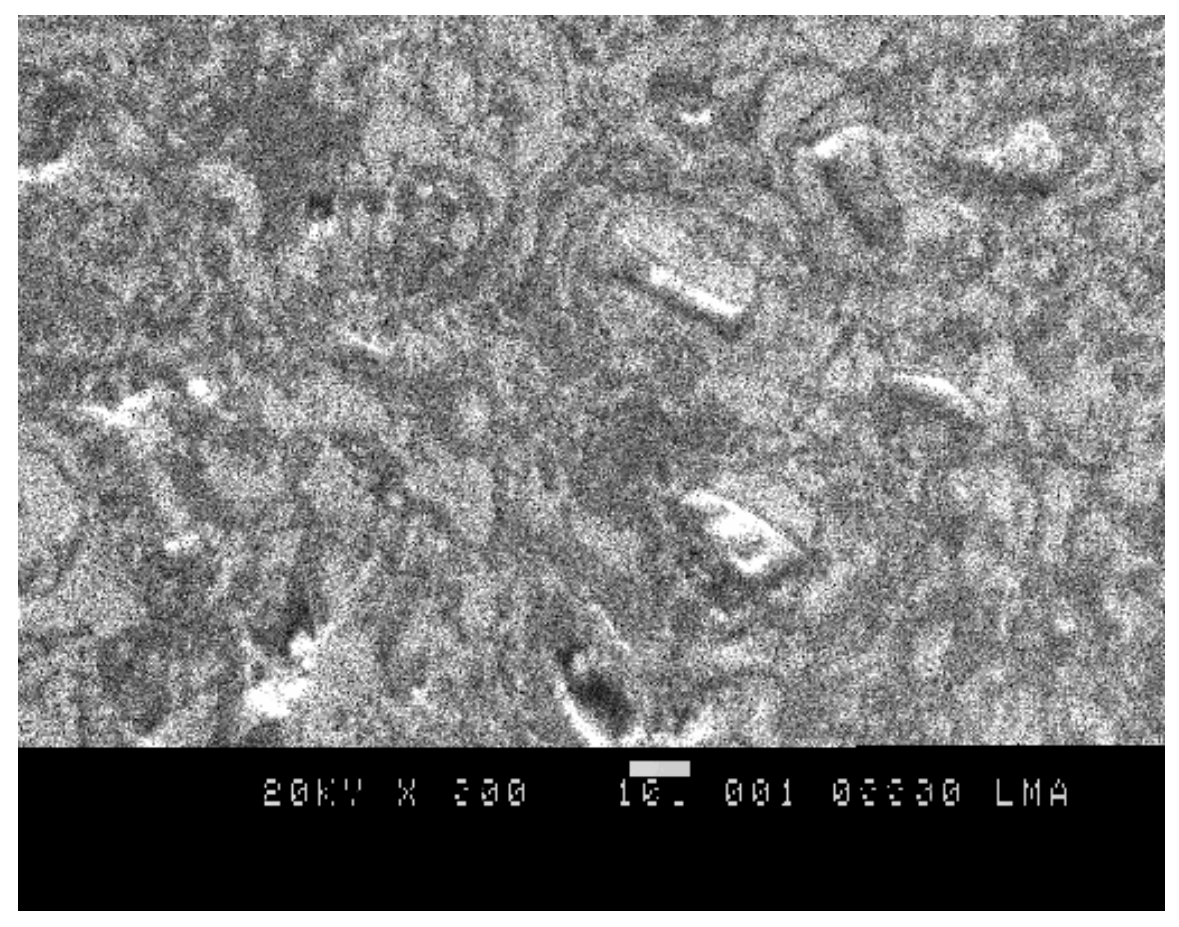

Figure 70: SEM micrograph of Alumina reinforced iron aluminide coating on $304 \mathrm{H}$ after cyclic oxidation, Showing alumina particles are still nicely bonded with Fe3Al matrix for protecting substrate 


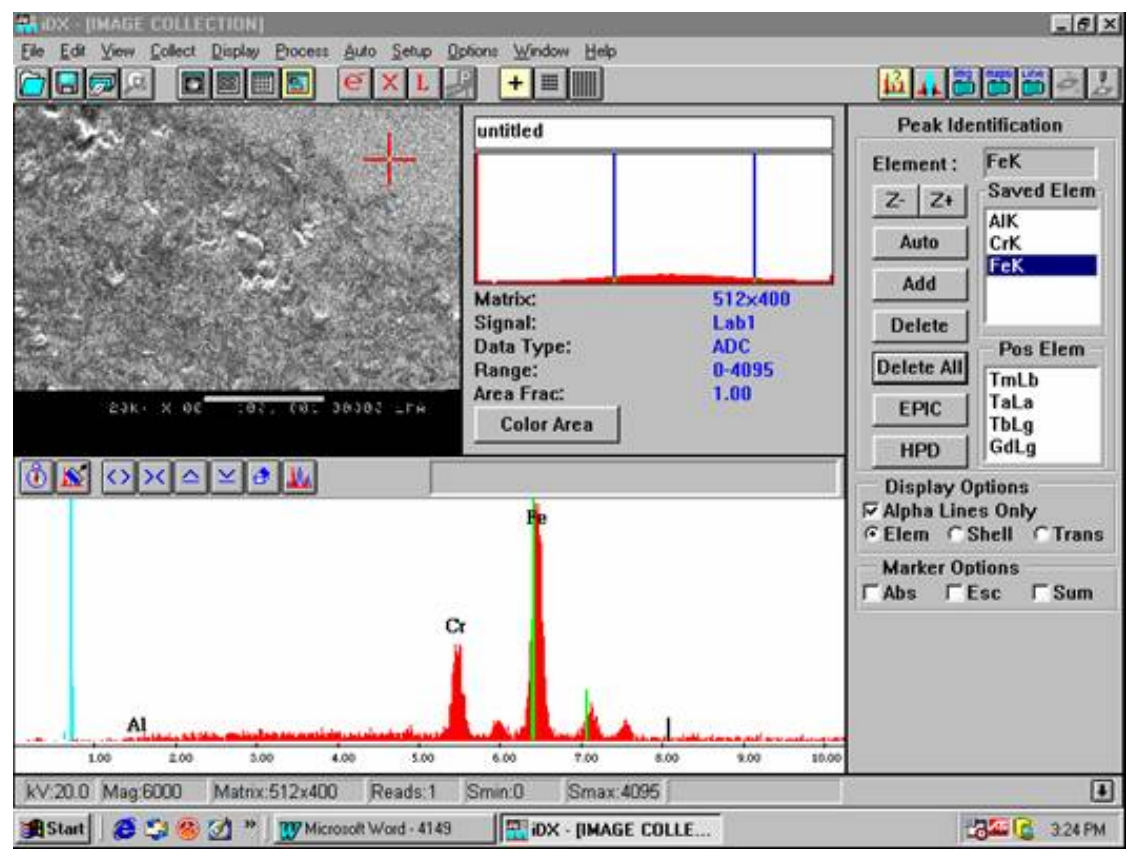

Figure 71:EDS analysis of $304 \mathrm{H}$ substrate

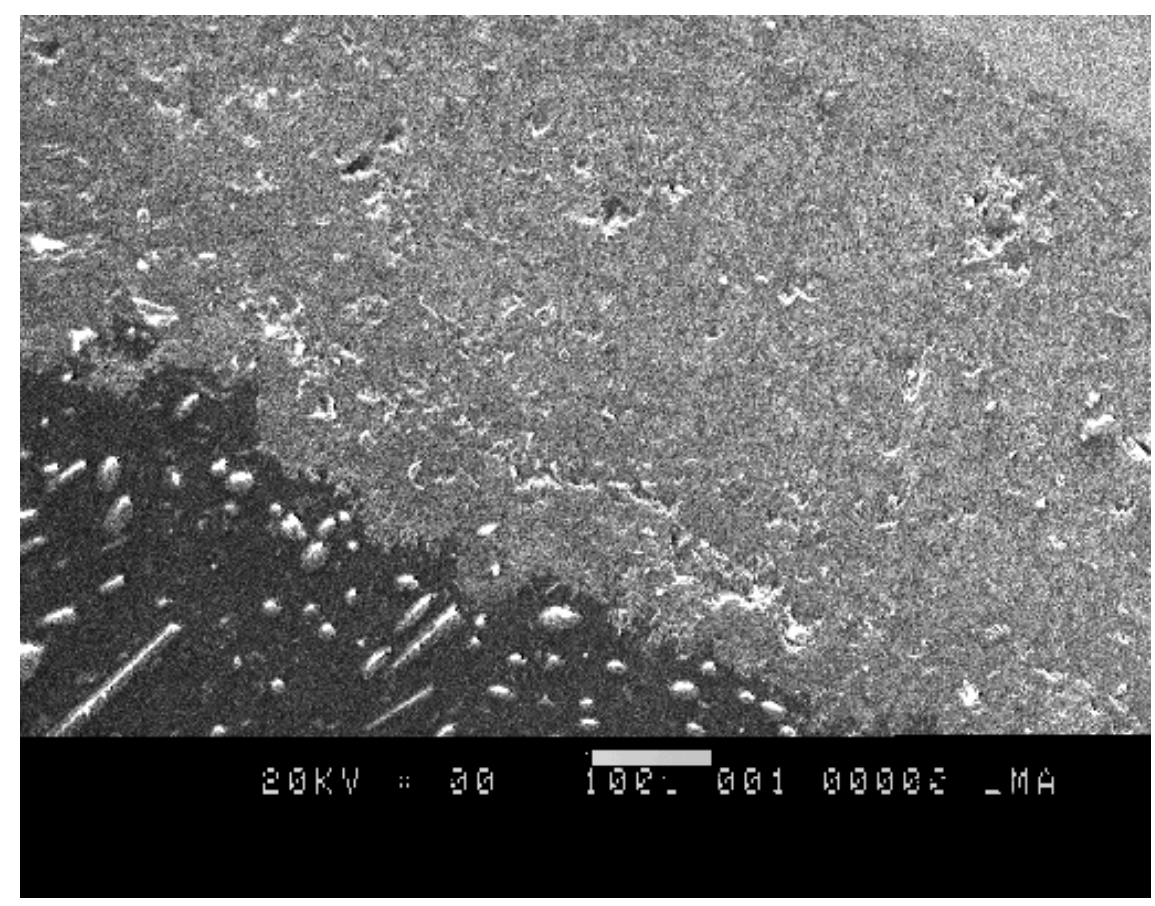

Figure 72: 100 micron oxide layer X140 


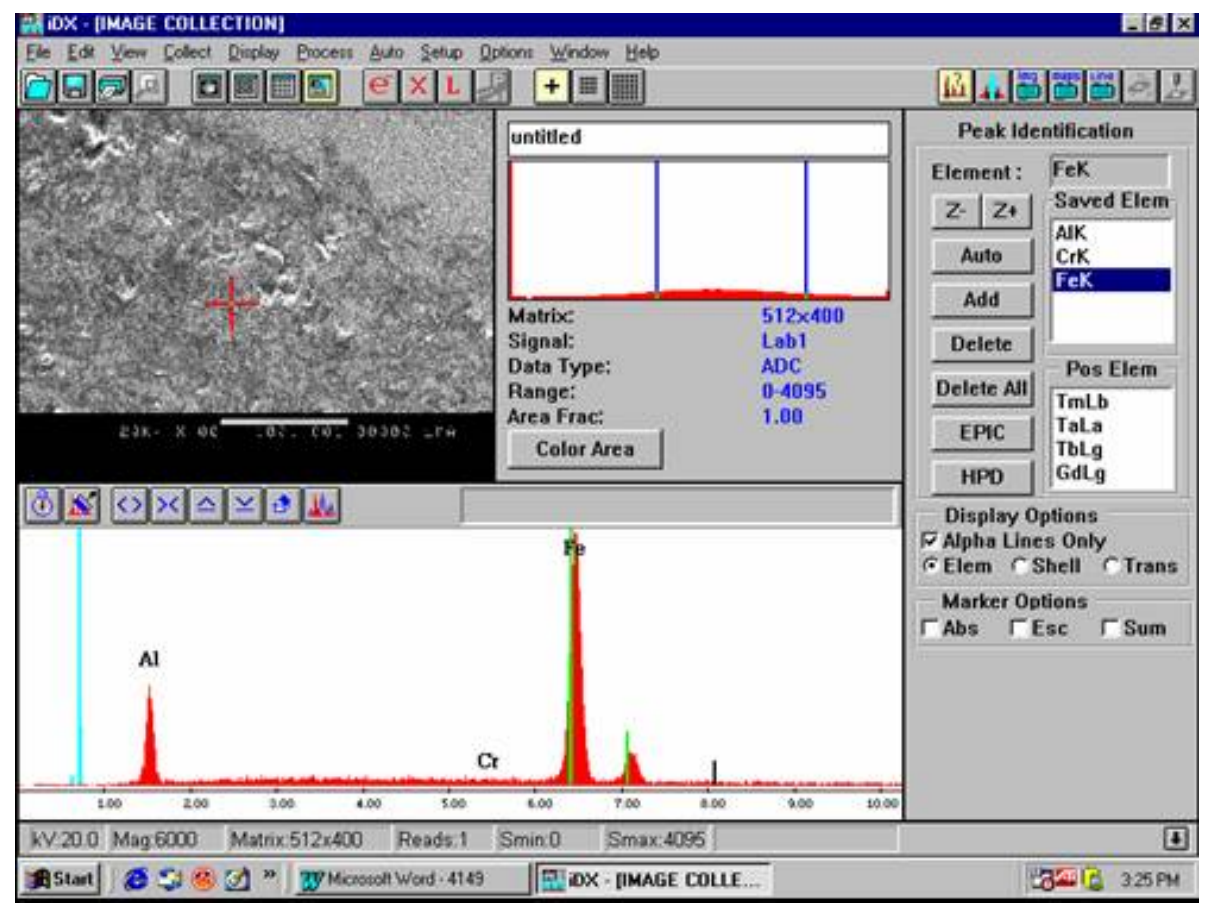

Figure 73: EDS analysis showing alumina reinforced Fe3Al coating

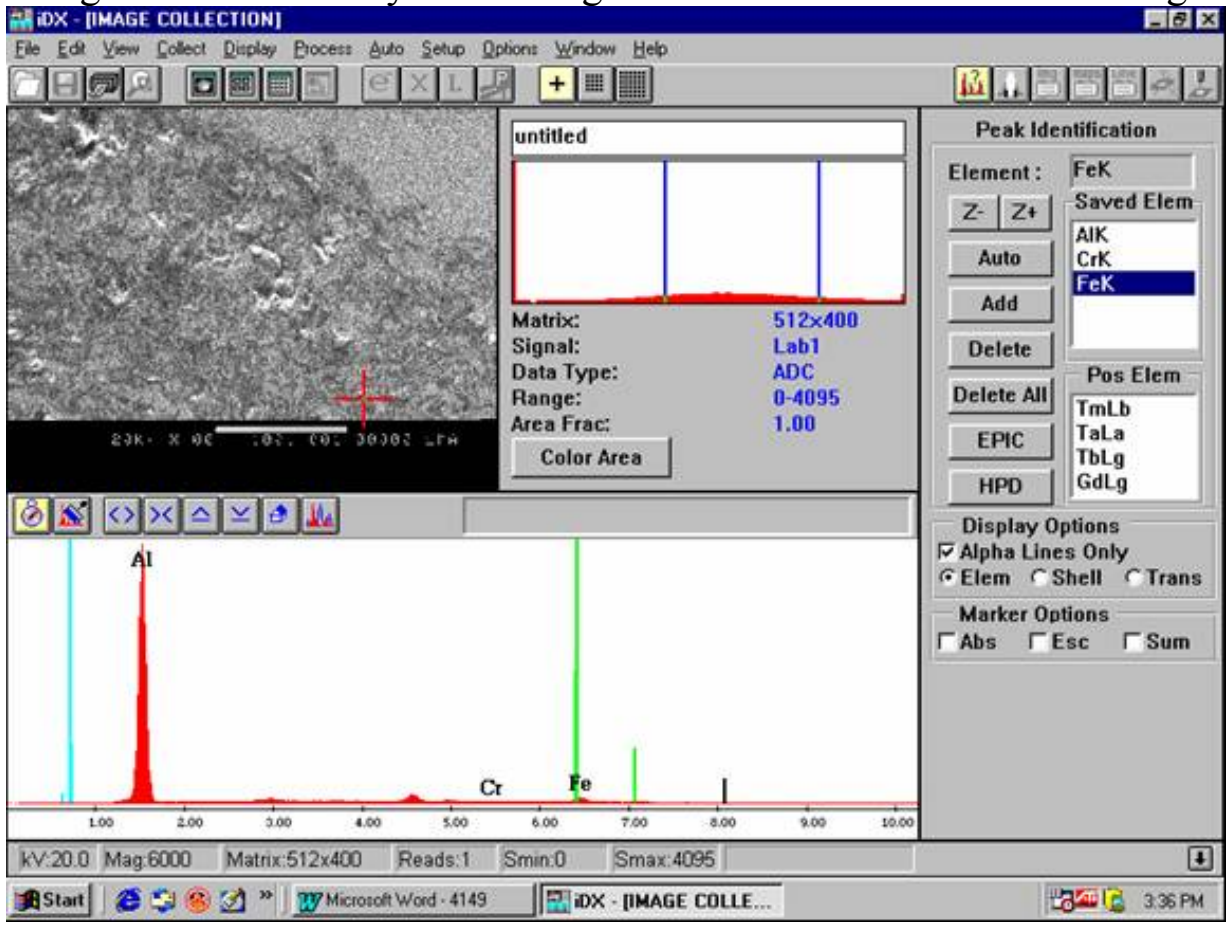

Figure 74: EDS analysis of alumina particles in $\mathrm{Fe}_{3} \mathrm{Al}$ - after oxidation 


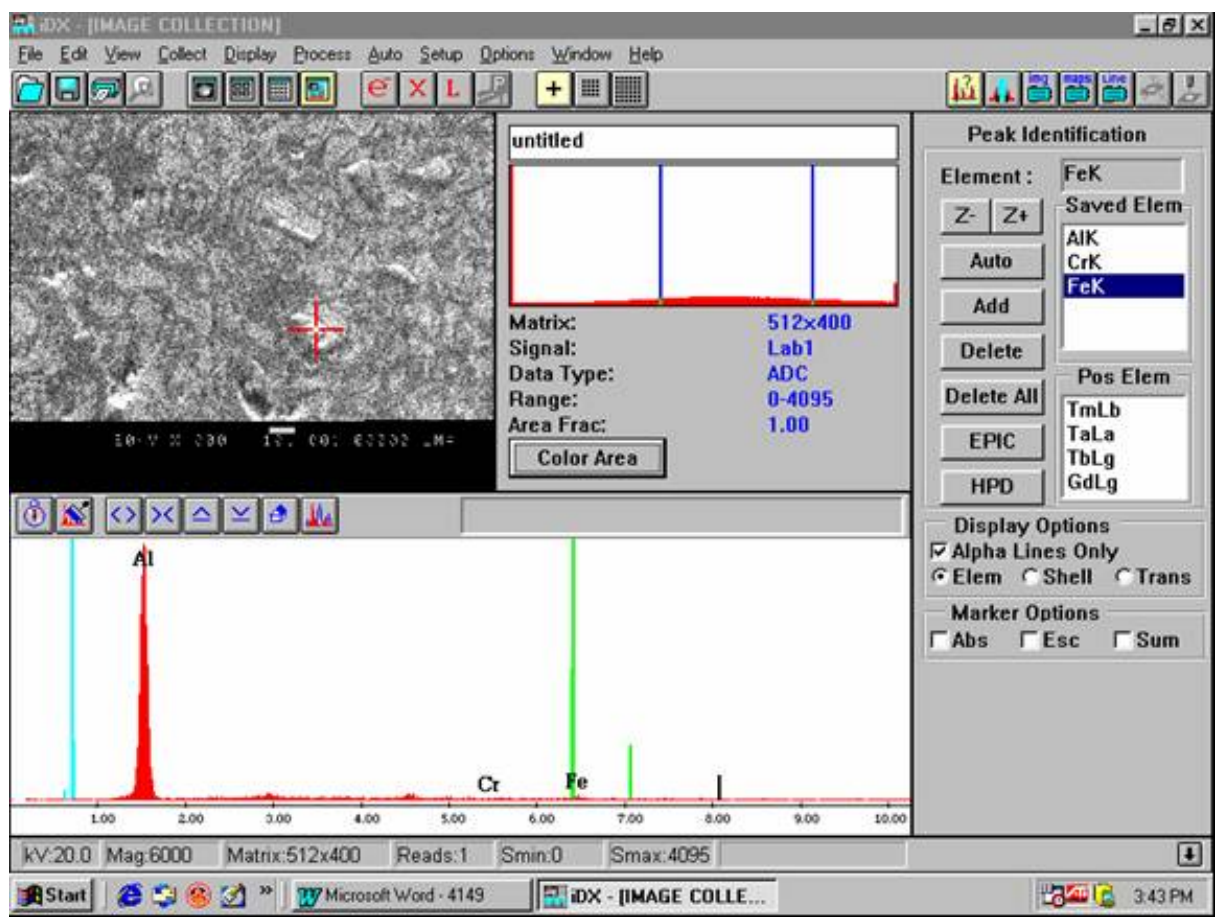

Figure 75: EDS Analysis showing that alumina particles are nicely bonded with iron aluminide matrix even after cyclic oxidation test

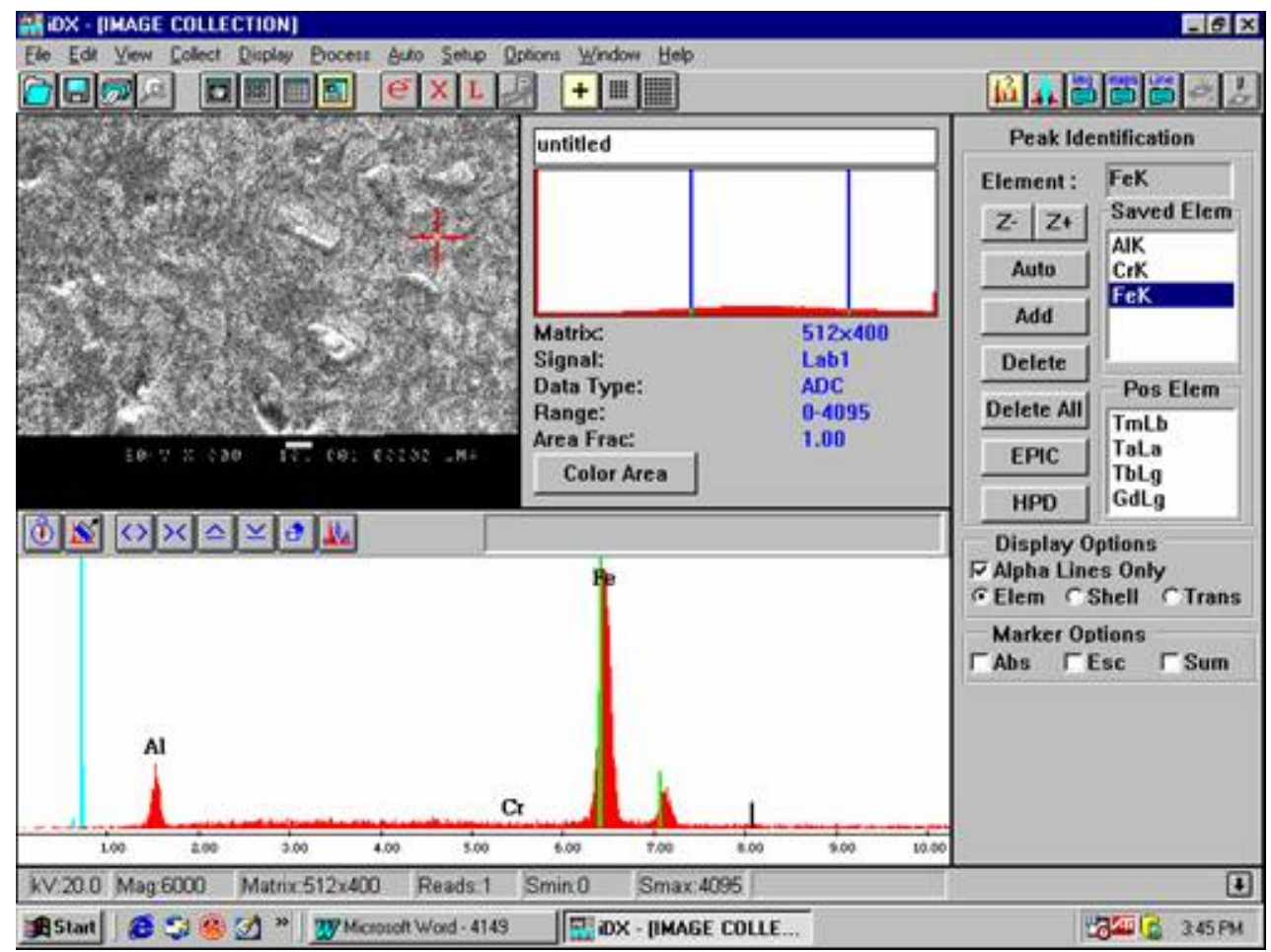

Figure 76: EDS analysis of Fe3Al matrix area of alumina reinforced Fe3Al coating 


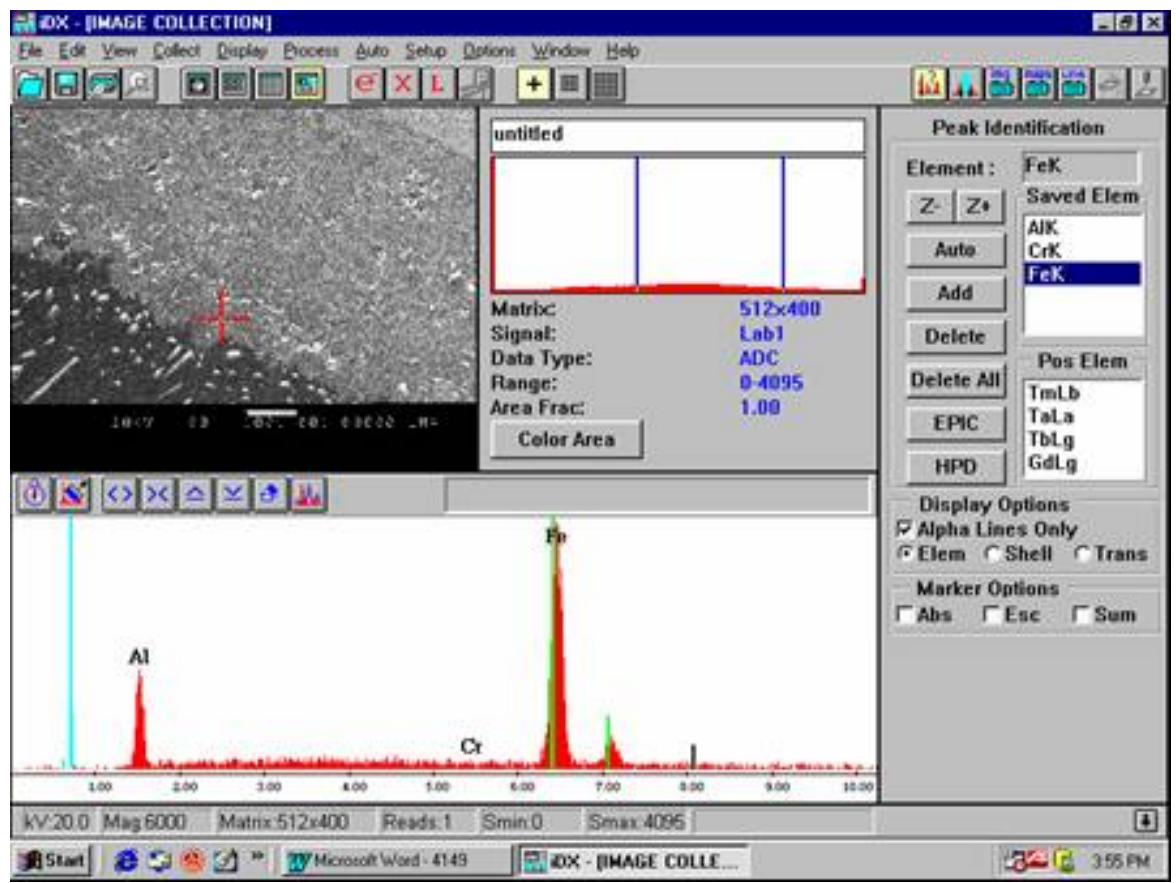

Figure 77: EDS analysis of alumina reinforced iron aluminide coating

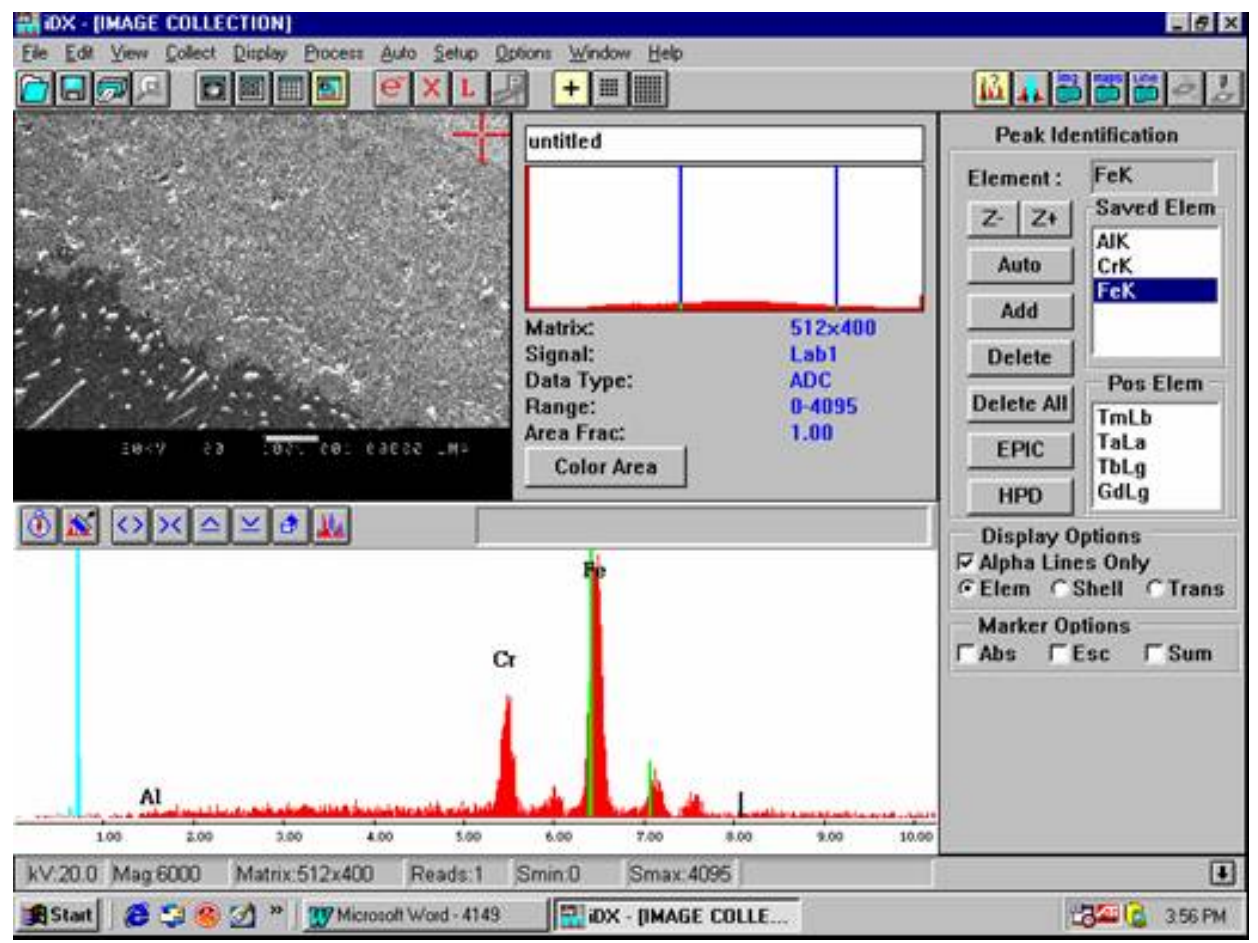

Figure 78: Show coating was not delaminated after cyclic oxidation. Alumina reinforced iron aluminide protected underneath substrate. Here EDS analysis showing the analysis of $304 \mathrm{H}$ substrate 


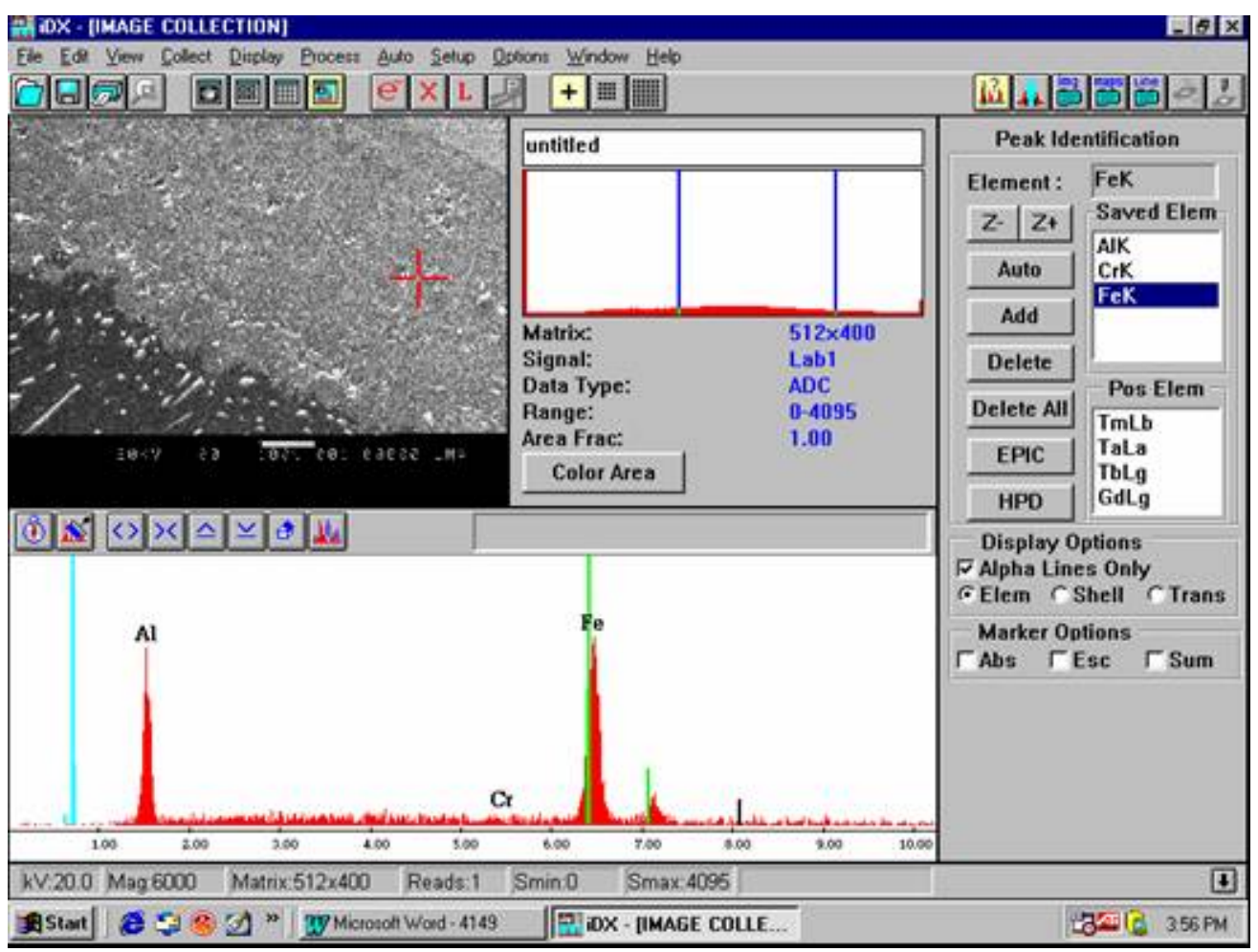

Figure 79: EDS analysis Showing Iron aluminide coating after cyclic oxidation

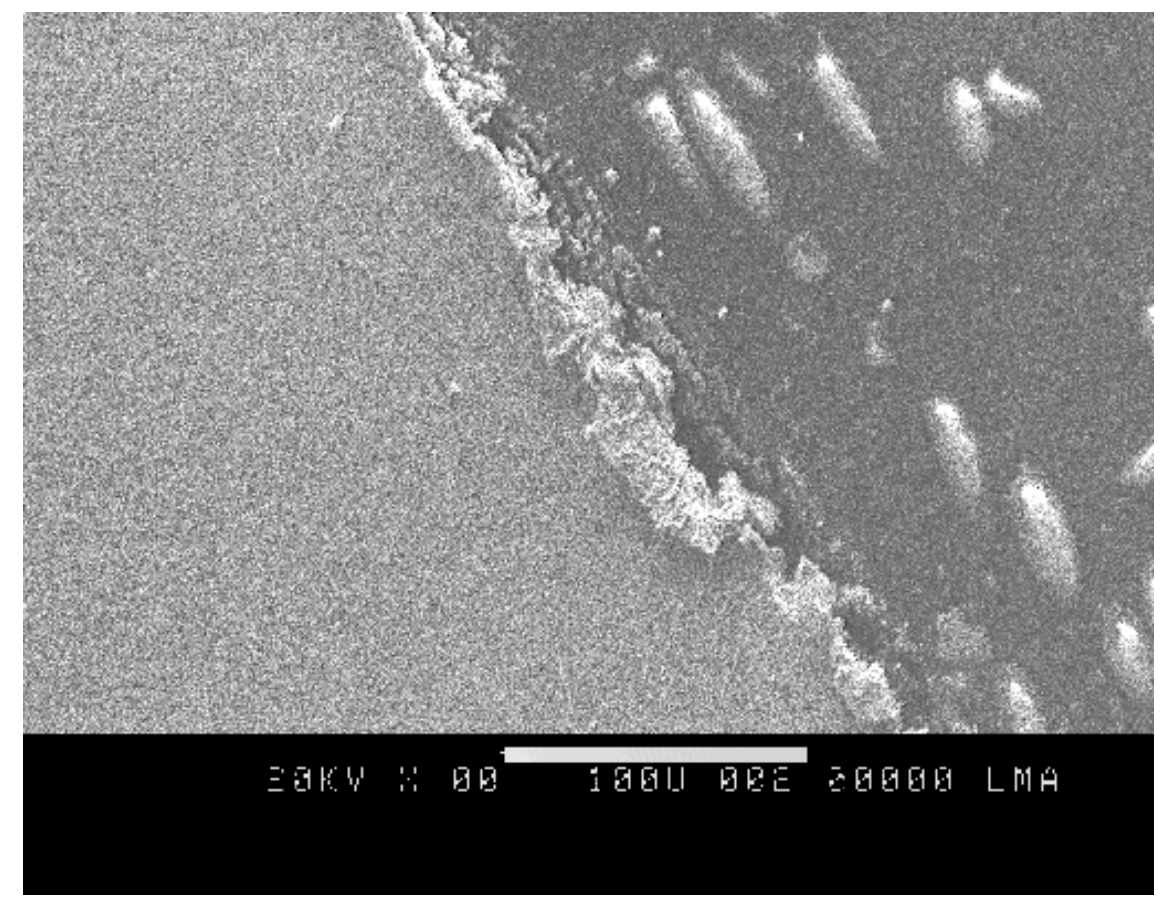

Figure 80: Uncoated $304 \mathrm{H}$ after cyclic oxidation test show oxide layers falling off while polishing X350 


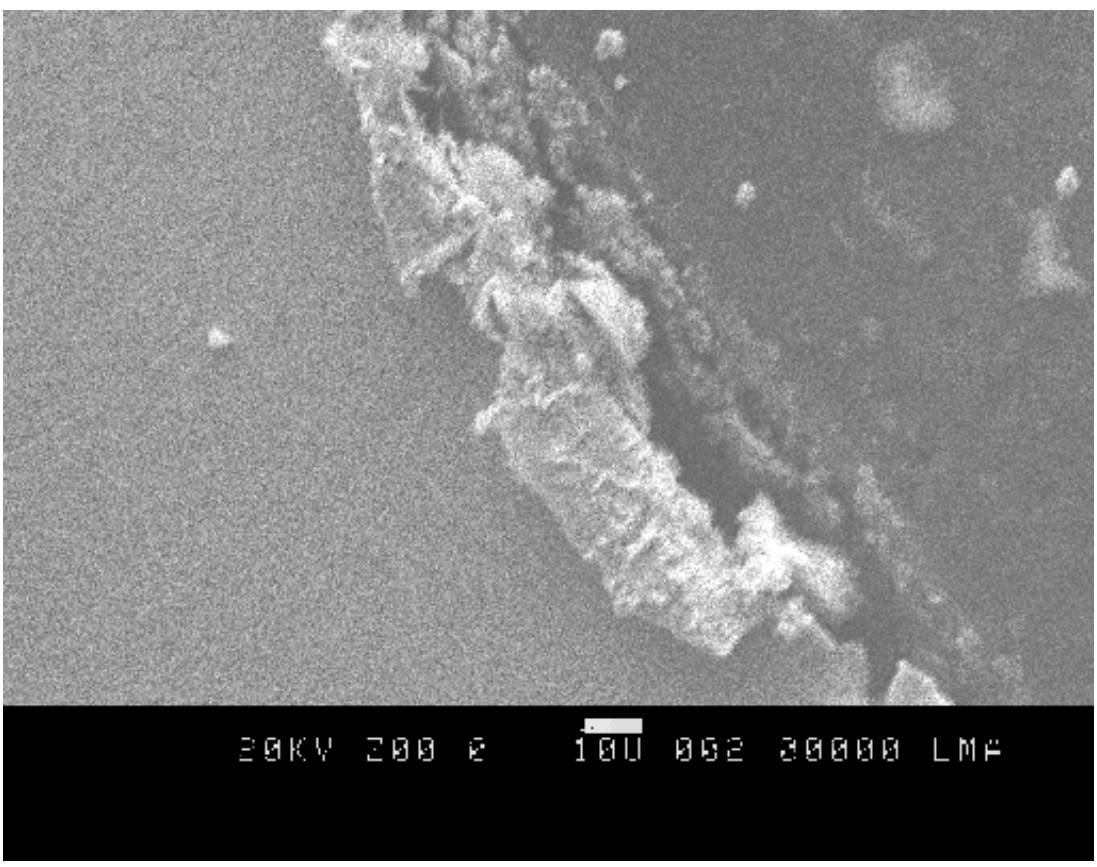

Figure 81 : Showing uncoated $304 \mathrm{H}$ after oxidation - Oxide layer spalling off and substrate was attacked by this cylic oxidation- show oxidation $\quad$ X700

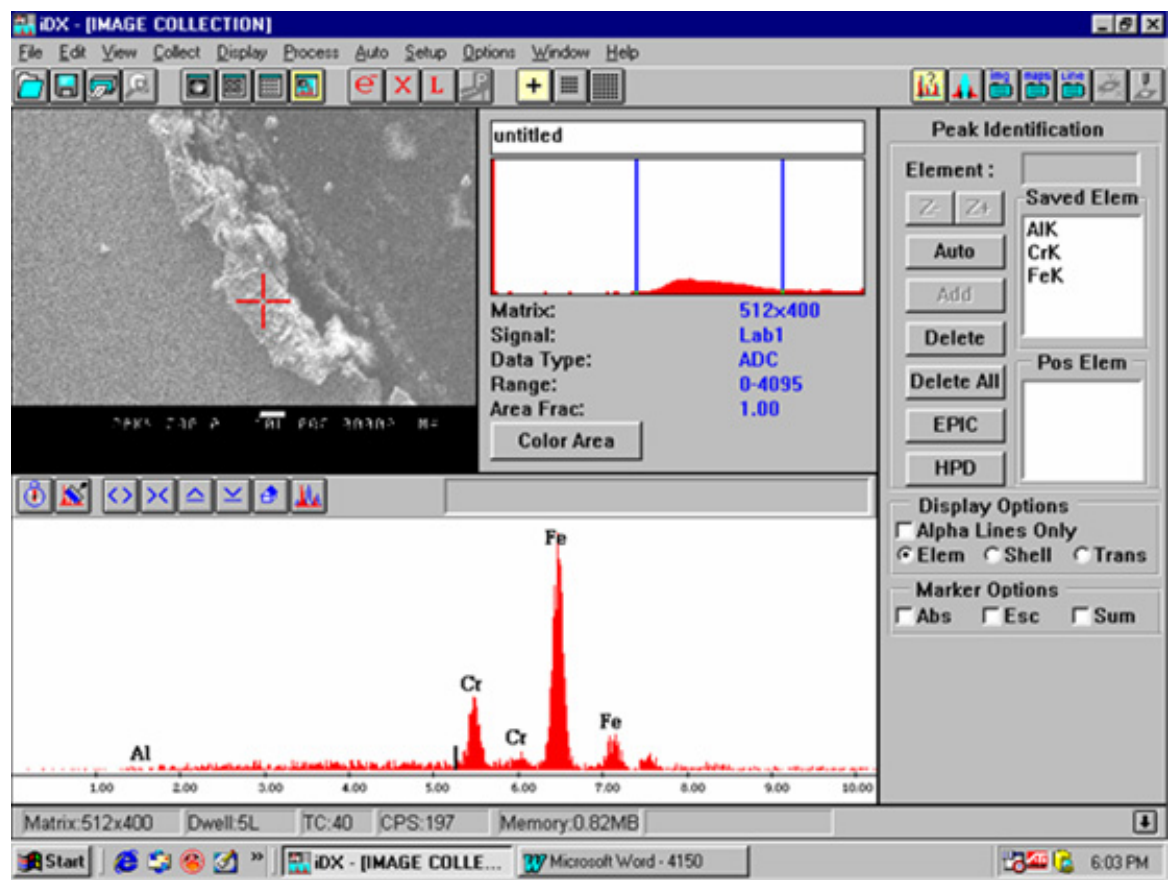

Figure 82: EDS analysis represent the layer is comprised of oxides of iron and chromium 


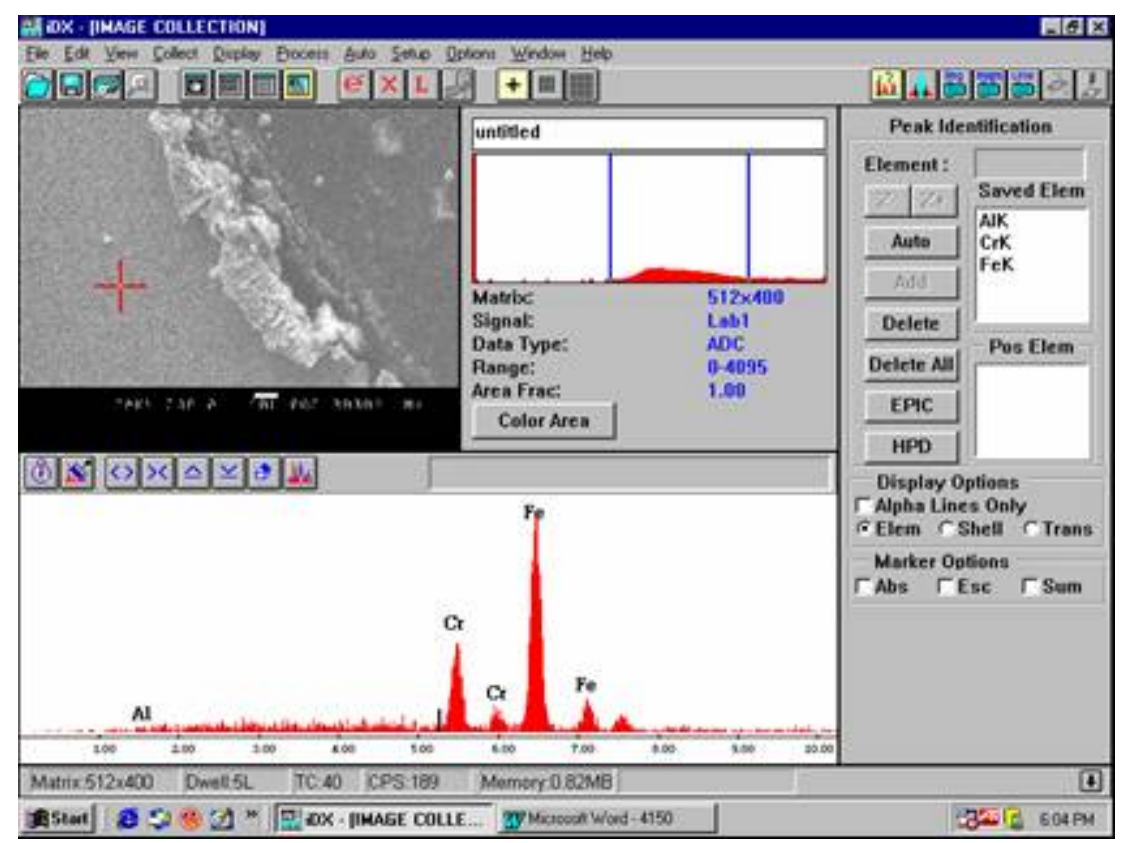

Figure 83: EDS analysis of $304 \mathrm{H}$ substrate after cyclic Oxidation test

Table 17: Oxidation Test Results of Fe3Al and Alumina Reinforced Fe3Al Coating on $304 \mathrm{H}$ and IN 718 Substrate

\begin{tabular}{|l|l|l|}
\hline \multicolumn{1}{|c|}{ Sample } & \multicolumn{1}{|c|}{ Type of coating } & \multicolumn{1}{|c|}{ Weight Gain $\left(\mathrm{mg} / \mathrm{cm}^{2}\right)$} \\
\hline $\mathrm{Fe}_{3} \mathrm{Al}$ on $304 \mathrm{H}$ & Plasma Spray & 1.03 \\
\hline $\begin{array}{l}\text { Alumina reinforced } \mathrm{Fe}_{3} \mathrm{Al} \\
\text { on } 304 \mathrm{H}\end{array}$ & Plasma Spray & 0.93 \\
\hline $\mathrm{Fe}_{3} \mathrm{Al}$ on 718 & Plasma Spray & 1.01 \\
\hline $\begin{array}{l}\text { Alumina reinforced } \mathrm{Fe}_{3} \mathrm{Al} \\
\text { on } 718\end{array}$ & Plasma Spray & 0.92 \\
\hline $\mathrm{Fe}_{3} \mathrm{Al}$ on 304 $\mathrm{H}$ & HVOF & 0.989 \\
\hline $\begin{array}{l}\text { Alumina reinforced } \mathrm{Fe}_{3} \mathrm{Al} \\
\text { on } 304 \mathrm{H}\end{array}$ & HVOF & 0.972 \\
\hline Fe $3 \mathrm{Al}$ on 718 & HVOF & 0.985 \\
\hline $\begin{array}{l}\text { Alumina reinforced } \mathrm{Fe}_{3} \mathrm{Al} \\
\text { on 718 }\end{array}$ & HVOF & 0.968 \\
\hline Uncoated 718 & No Coating & 1.95 \\
\hline Uncoated 304 H & No Coating & 2.15 \\
\hline Medium Carbon Steel & No coating & 3.55 \\
\hline
\end{tabular}


From the SEM microscopy and oxidation test results it was concluded that uncoated steel, IN 718 and $304 \mathrm{H}$ were severely attacked by this cyclic oxidation, But $\mathrm{Fe}_{3} \mathrm{Al}$ and alumina reinforced $\mathrm{Fe}_{3} \mathrm{Al}$ coating sprayed on $\mathrm{IN} 718$ and $304 \mathrm{H}$ protected the $304 \mathrm{H}$ and IN 718 substrate. Coatings were adherent to substrate, did not spall off during and after oxiadation test. It was also found that oxidation rate of alumina reinforced iron aluminide coating was lower than the iron aluminide coating sprayed on both the substrate and oxidation rate of plasma spray coating was slightly higher than the HVOF coating. But once again both coating showed oxidation resistant properties and protected the substrate.

\subsection{CONCLUSIONS:}

This I\&I program developed CVD iron, aluminum, aluminum oxide coated iron powders and iron, aluminum coated alumina powders for fabricating Oxide Dispersion Strengthened Iron aluminide and alumina particle reinforced iron aluminide composites and their thermal spray coating for future power generation equipment.

This program demonstrated ODS iron aluminide and alumina reinforced iron aluminide composites by $\mathrm{CIP} /$ sinter and $\mathrm{CIP} /$ extrusion route with good mechanical properties. Mechanical properties could be better with further investigation of few more consolidation steps after extrusion. But in this study composite development by $\mathrm{CIP} /$ extrusion and their room temperature property improvement was not pursued further in detail. More focus was given on high temperature oxidation, carburization and corrosion resistant thermal sprayed coating and their microstructure development .

Composite's mechanical property results yielded mechanical properties nearly equivalent to MA754, MA758 MA956, and even mechanical strength is superior to MA956 in the case of ODS iron aluminide, with nearly double the properties of current SOTA P/M 410L ferritic steel materials.

This program clearly demonstrated the potential of the Vapor Phase Synthesis of Nanoengineered Powders (VPSNP) process for enabling improved dispersion strengthened materials by CIP/extrusion route and iron aluminide coating by thermal spray (Plasma spray and HVOF) to be produced at reduced costs and improved performance, compared to current iron aluminide or MA956 SOTA materials. In case of thermal spray coating from the results, the potential of thermal sprayed (Plasma Spray and $\mathrm{HVOF}$ ) $\mathrm{Fe}_{3} \mathrm{Al}$ and alumina reinforced $\mathrm{Fe}_{3} \mathrm{Al}$ coatings to control oxidation, carburization and corrosion environments such as for the future coal fired power generation component is clear. The following conclusions can be drawn:

1) Thermal spray coatings do not catastrophically fail in high oxidizing and corrosion environments

2) Aluminum, iron, aluminum oxide, coated iron powders and aluminum, iron, coated alumina is sprayable using High Velocity Oxy-Fuel (HVOF) and Plasma Spray Process with excellent adhesion to $304 \mathrm{H}$ and Inconel 718 series substrates. 
3) Powdermet's $\mathrm{Fe}_{3} \mathrm{Al}$ and alumina reinforced $\mathrm{Fe}_{3} \mathrm{Al}$ coating's hardness is comparable to that of hardened $304 \mathrm{H}$ stainless steel.

4) Thermally sprayed $\mathrm{Fe}_{3} \mathrm{Al}$ and alumina reinforced $\mathrm{Fe}_{3} \mathrm{Al}$ exhibit no catastrophic corrosion failure in the presence of $\mathrm{Fe}_{2} \mathrm{O}_{3} / \mathrm{K}_{2} \mathrm{SO}_{4}$ and $\mathrm{Na}_{2} \mathrm{SO}_{4}$.

5) HVOF and plasma sprayed coatings exhibit no delamination or other catastrophic failure during oxidation, conditions.

6) Plasma spray and HVOF iron aluminide coating exhibits low erosion rates against alumina grit erosion test

7) A problem encountered with plasma spraying submicron micro-engineered powders is flowability within the plasma and HVOF systems. In particular problem was severe incase of $\mathrm{HVOF}$ coating of $\mathrm{Fe}_{3} \mathrm{Al}$. Additional work on granulation for increasing powder flow is required to increase deposition efficiency rates and to optimize deposition parameters further.

In summary, this study clearly demonstrated that thermally sprayed iron aluminide and alumina reinforced iron aluminide coatings can survive under oxidation, carburization and can provide improvements in corrosion condition. It is also expected that CIP/ sintered and $\mathrm{CIP} /$ extrude/roll route of $\mathrm{Fe}$, Al coated iron and alumina powders will be applicable for future power generation equipment and will be further studied in future for further development. While the results of these initial iron aluminide property measurements are encouraging, but more measurements of iron aluminide properties are needed with the execution of a broader test matrix such as FeAl, particularly for establishing properties for future use. For composite detail characterization of high temperature tensile, creep, fatigue test and for coatings simulated NOx atmosphere test , more severe steam oxidation test, and hot corrosion test and mechanical properties are needed. The recommended follow-on plan for further optimization and maturation of this technology (composite and coating fabrication) will require the conduct of further optimization of a broader test matrix iron aluminide composite/coating properties, the development of processing for high tensile, ductile ODS iron aluminide, the fabrication of near-net-shaped components, tube fabrication, along with viable methods for their joining to, and integration with the associated boiler structures. Another continuation program should focus on scale up development considerations in CIP/extrude/hot rolling/warm or cold rolling route and thermal spray coating development in detail. The main object of the later follow-on investigation is to move from batch process to a factory-wise continuous-reactor system implementing a candidate technology, namely the CVD powder coating for fabrication of iron aluminide composite fabrication and thermal coating development for future power generation equipment

\section{0: RECOMMENDATIONS}

So the processing optimization in this I\&I program took the pathway proposed this program which the factory-processing-adaptable, scale-up trials using the 
CIP/extrusion/rolling process received only limited attention, before it was abandoned due to poor room temperature properties, breaking of samples while machining and the need for room temperature property modifications, and further out-of-scope consolidation development, and financial need. The CIP/sinter process trials had to be sacrificed (at the program outset) for the more critical processing-microstructure-property optimization effort and the more readily available thermal spray method using this powder. Also the foregoing I \&I Program executions made it more apparent that alumina reinforced iron aluminide coating would be potentially more viable for use as an integral part of future boiler components for retrofitting existing equipment. With such generic considerations in mind the following specific recommendations can be made in the wake of the current Program completion:

(1) In view of the encouraging property trade study results obtained so far in this investigation, a viable follow-up plan for further optimization and maturation of this technology will require the conduct of a further Phase- I SBIR Program for further optimization of the iron aluminide properties, and another Phase II focusing on scale up development considerations. The main object of these follow-on investigations is to evolve to improve room temperature ductility factory-wise continuous-reactor process using the CVD coated powders and thus successfully replace the current batch processing methods. The execution of these Phases will be required before proceeding to a Phase III - Technology Transition.

(2) The processing optimization follow-on plan should also focus not only on further enhancement of the intrinsic properties of the iron aluminide itself, but also to develop the technology needed for fabrication of useful power generation component /joining by this iron aluminide to replace current expensive nickel base alloys . This phase of work should also consider a broader iron aluminide characterization test matrix at the component test level.

(3) Follow-on work activities should also consider the development and fabrication of near-net-shaped extruded /rolled or forged elements, and the methods of their attachment to, and integration with the associated power generation such as boiler equipment structures. 